CENTRO UNIVERSITÁRIO FEI

FERNANDO OLIVEIRA SOUZA DA SILVA 
FERNANDO OLIVEIRA SOUZA DA SILVA

\section{ESTUDO DE DIODOS PIN FABRICADOS EM SUBSTRATOS SOI OPERANDO COMO CÉLULAS SOLARES}

Dissertação de Mestrado
apresentada ao Centro Universitário da
FEI como requisito parcial para a
obtenção do título de Mestre em
Engenharia Elétrica. Orientado pelo Prof.
Dr. Rodrigo Trevisoli Doria.

São Bernardo do Campo - SP 2018 
Oliveira Souza da Silva, Fernando.

Estudo de diodos PIN fabricados em substratos SOI operando como células solares / Fernando Oliveira Souza da Silva. São Bernardo do Campo, 2018. 105 p. : il.

Dissertação - Centro Universitário FEI.

Orientador: Prof. Dr. Rodrigo Trevisoli Doria.

1. diodos PIN. 2. tecnologia SOI. 3. células solares. 4. geração de énergia. 5. rendimento e fator de forma. I. Trevisoli Doria, Rodrigo, orient. II. Titulo.

CDU 621.383 
Título do Trabalho: Estudo de diodos PIN fabricados em substratos SOI operando como células solares.

Área de Concentração: Nanoeletrônica e Circuitos Integrados

Orientador: Prof. Dr. Rodrigo Trevisoli Doria

Data da realização da defesa: 08/02/2018

\section{ORIGINAL ASSINADA}

\section{Avaliação da Banca Examinadora:}

São Bernardo do Campo, 08 / 02 / 2018.

\section{MEMBROS DA BANCA EXAMINADORA}

Prof. Dr. Rodrigo Trevisoli Doria

Prof. Dr. Renato Camargo Giacomini

Prof. a Dr. a Maria Glória Caño de Andrade
Ass.:

Ass.:

Ass. :

A Banca Julgadora acima-assinada atribuiu ao aluno o seguinte resultado:

APROVADO \

REPROVADO

\section{VERSÃO FINAL DA DISSERTAÇÃO}

APROVO A VERSÃO FINAL DA DISSERTAÇÃO EM QUE FORAM INCLUÍDAS AS RECOMENDAÇÕES DA BANCA EXAMINADORA
Aprovação do Coordenador do Programa de Pós-graduação

Prof. Dr. Carlos Eduardo Thomaz 
Dedico este trabalho principalmente aos meus pais, Maria e José, meu irmão Márcio e amigos que me deram amor, formação moral e fundamental com o objetivo de me preparar para todos os obstáculos e desafios até aqui vivenciados, e para vencer mais este certame. 


\section{AGRADECIMENTOS}

Agradeço ao meu orientador e amigo Prof. Dr. Rodrigo Trevisoli Doria, por toda compreensão, dedicação, apoio e estímulo desde o momento em que ingressei no curso.

Aos professores Dr. Marcelo Antonio Pavanello, Dra. Michelly de Souza, Dr. Renan Trevisoli Doria, Dr. Renato Camargo Giacomini, Dr. Salvador Pinillos Gimenez e Dr. Rudolf Bühler por todo o apoio, experiência e conhecimento passados para a minha investidura em mais esta etapa importante.

Aos meus pais, José e Maria, meu irmão Márcio e todos os amigos e familiares que me apoiaram desde o início deste certame.

A Ângela de Fátima Torres pelo apoio psicológico, emocional e moral durante toda a minha carreira de estudante até o presente momento.

A CAPES pela bolsa de estudos que proporcionou a realização do curso tanto quanto desta pesquisa. 
"O conhecimento serve para encantar as pessoas, não para humilhalas."

MARIO SERGIO CORTELLA 


\section{RESUMO}

O trabalho apresentado demonstra o uso de diodos PIN fabricados no substrato de lâminas de tecnologia SOI, operando como células solares, visando à conversão de energia solar em eletricidade. A implementação de tais dispositivos no substrato das lâminas tem como objetivo a construção de sistemas autônomos, em que os diodos PIN possam prover energia suficiente para os circuitos na parte ativa da lâmina. $O$ foco da pesquisa atual sobre o dispositivo acima mencionado consiste na relação do comprimento de sua região com dopagem intrínseca com os resultados em termos de rendimento e fator de forma, dados fundamentais na caracterização de uma célula solar. A célula apresentada aqui demonstra resultados com rendimento variando entre 7 e $8 \%$ e fator de forma com média da ordem de $80 \%$. A princípio foram utilizados dispositivos PIN sem porta e foram feitas simulações com a ferramenta Sentaurus com fonte de luz monocromática e um espectro solar completo em seguida. Na sequência, foi implementada uma porta à estrutura do dispositivo e aplicada, a esta, diferentes polarizações ( 0 e $5 \mathrm{~V}$ ) para comparar seus resultados aos dos dispositivos sem porta. Por fim, foram consideradas diferentes temperaturas de operação, visando obter resultados mais próximos das situações reais de funcionamento.

Palavras-chave: Diodos PIN, tecnologia SOI, células solares, geração de energia, rendimento e fator de forma. 


\begin{abstract}
This work demonstrates the use of PIN diodes fabricated in the substrate of SOI wafers, operating as solar cells in the conversion of solar energy into electricity. The implementation of such devices is the substrate of the wafers aims at the confection of autonomous systems where PIN diodes provide enough energy to the circuits on the active silicon layer. The research focuses on the relation between the device intrinsic length and what it provides in terms of efficiency and fill factor, fundamental parameters for the solar cell characterization. The studied cell have shown efficiency of about $7 \%$ to $8 \%$ and fill factor with average about $80 \%$. Originally, ungated PIN devices have been considered in Sentaurus simulations with a monochromatic light source and a complete solar spectrum afterwards. In the sequence, a gate has been implemented on the device, considering different biases ( $0 \mathrm{~V}$ and $5 \mathrm{~V}$ ) in order to compare itself with the ungated diodes ones. Lastly, different operation temperatures have been applied into simulations, aiming to achieve results closer to real operation conditions.
\end{abstract}

Keywords: PIN diodes, SOI technology, solar cells, current generation, efficiency and fill factor. 


\section{LISTA DE ILUSTRAÇÕES}

Figura 1 - Espectro total e espectro visível ou eletromagnético.

Figura 2 - Incidência da radiação solar relacionando absorção, reflexão e difusão.

Figura 3 - Gráfico da densidade de potência em função do comprimento de onda a partir dos espectros AM1.5G e AM1.5D e a difusão do espectro (Diff).... 24

Figura 4 - Gráfico do comprimento de absorção em função do comprimento de onda do silício.

Figura 5 - Perda de intensidade da incidência de luz no silício em função de sua profundidade.

Figura 6 - Esquema de banda de energia com nível de Fermi para semicondutor intrínseco. 28

Figura 7 - Esquema da dispersão e os tipos de transição que a energia sofre..... 31

Figura 8 - Curva relacionando as características elétricas que originam o Fator de Forma.

Figura 9 - Representação gráfica da área formada pelo fator de forma no quarto quadrante

Figura 10 - Ilustração da junção PN e região de depleção

Figura 11 - Diodo semicondutor: símbolo, curva I x V do diodo ideal e do diodo real

Figura 12 - Gravura simplificada do efeito fotovoltaico em uma placa solar vertical feita a partir de uma junção PN.

Figura 13 - Esquema do funcionamento do diodo PIN absorvendo energia ótica. 47

Figura 14 - Representação gráfica da curva da corrente quando se opera a célula solar no diodo PIN no terceiro e quarto quadrante.

Figura 15 - Ilustração legendada de um transistor MOS implementado com a tecnologia SOI.

Figura 16 - Comparação das tecnologias SOI e CMOS em relação à integração de circuitos

Figura 17 - Diodo PIN fabricado em tecnologia SOI, vista frontal.

Figura 18 - Esquema de um diodo PIN fabricado em substrato SOI 
Figura 19 - Célula Solar com porta, fabricada na tecnologia SOI.

Figura 20 - Gráfico experimental para validação das simulações.

Figura 21 - Curvas características das correntes de cada dispositivo simulado... 63

Figura 22 - Curva da potência pela tensão e abaixo curva da corrente pela tensão.

Figura 23 - Curva relacionando potência máxima e fator de forma com o comprimento intrínseco para um diodo PIN com espessura de substrato de 80 nanômetros.

Figura 24 - Curvas de tensão pela corrente em escala logarítmica dos dispositivos simulados, separados pelo comprimento intrínseco

Figura 25 - Gráfico de potência máxima e potência incidente para um diodo PIN com espessura de substrato de $2 \mu \mathrm{m}$.

Figura 26 - Curvas de Voc (tensão de circuito aberto) e Isc (corrente de curto circuito) e seus comportamentos

Figura 27 - Gráfico sobre fator de forma e rendimento dos dispositivos já simulados e apresentados

Figura 28 - Curvas características dos dispositivos com tensão nula.

Figura 29 - Curvas características para tensão $\mathrm{Vg}=5 \mathrm{~V}$.

Figura 30 - Relação potências e comprimentos intrínsecos dos dispositivos com tensão nula e 5 volts

Figura 31 - Tensão de circuito aberto Voc relacionada ao comprimento intrínseco.

Figura 32 - Relação Corrente de curto circuito "Isc" com Li.

Figura 33 - Curvas de rendimento e fator de forma em relação ao comprimento intrínseco do primeiro dispositivo com porta.

Figura 34 - Comparação dos resultados entre dispositivo sem porta e

dispositivo com porta e tensão nula.

Figura 35 - Curva característica do dispositivo trabalhando a $325 \mathrm{~K}$ e tensão nula.

Figura 36 - Curva característica do dispositivo trabalhando a $325 \mathrm{~K}$ e tensão de 5 volts.

Figura 37 - Curva característica do dispositivo trabalhando a $350 \mathrm{~K}$ e tensão nula. 
Figura 38 - Curva característica do dispositivo trabalhando a 350K e tensão de 5 volts.

Figura 39 - Gráfico dos valores máximos de potência e potência incidente de ambas as tensões para $\mathrm{T}=325 \mathrm{~K}$ e $\mathrm{T}=350 \mathrm{~K}$

Figura 40 - Valores de corrente de curto circuito (Isc) e tensão de circuito aberto (Voc) para $\mathrm{T}=325 \mathrm{~K}$ e com variação da tensão de porta

Figura 41 - Valores de corrente de curto circuito (Isc) e tensão de circuito aberto (Voc) para $\mathrm{T}=350 \mathrm{~K}$ e com variação da tensão de porta.

Figura 42 - Comportamento do fator de forma relacionado ao aumento de temperatura.

Figura 43 - Comparação entre os rendimentos relacionados por temperatura e tensão de porta ao comprimento intrínseco.

Figura 44 - Linearidade na queda dos rendimentos dos dispositivos de $2 \mu \mathrm{m}$ e $12 \mu \mathrm{m}$ de acordo com a temperatura, para tensão de 0 volts. 


\section{LISTA DE TABELAS}

Tabela 1 - Relação entre os comprimentos intrínsecos e os valores

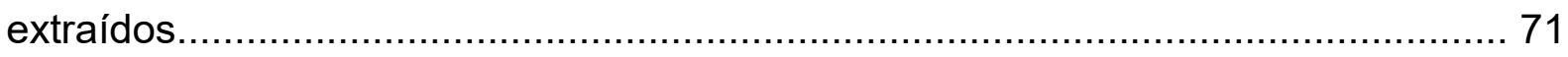




\section{SUMÁRIO}

1 INTRODUÇÃO

1.1 O PROBLEMA APRESENTADO E SUA JUSTIFICATIVA............................ 17

1.2 COLETA E ANÁLISE DE DADOS PARA DESENVOLVER O TEMA............... 18

2 FUNDAMENTAÇÃO TEÓRICA …….................................................... 19

2.1 ENERGIA SOLAR PARA PRODUÇÃO DE ENERGIA ELÉTRICA................ 19

2.1.1 O Espectro Solar ....................................................................... 21

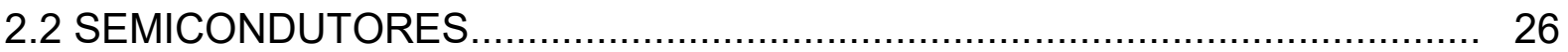

2.2.1 Propriedades Óticas nos Semicondutores........................................ 30

2.2.2 Eficiência Quântica....................................................................... 32

2.2.3 Efeito Fotovoltaico.................................................................

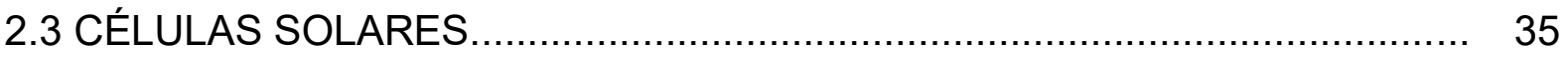

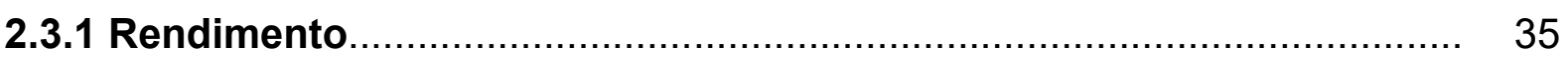

2.3.2 Fator de Forma

2.3.3 Tipos de Células Solares.............................................................. 38

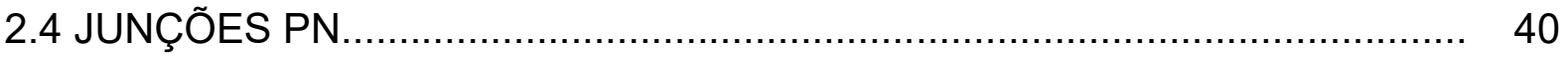

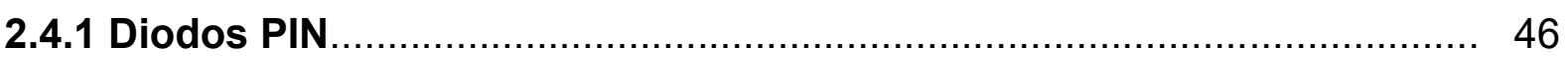

2.5 TECNOLOGIA SOI (Silicon-on-Insulator)................................................. 48

2.5.1 Diodos PIN fabricados em tecnologia SOI....................................... 51

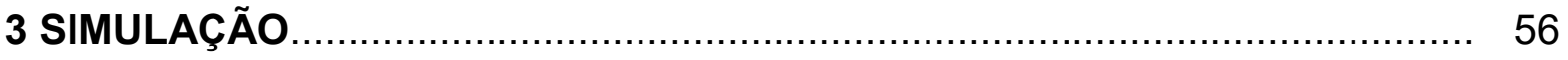

3.1 SIMULADOR SYNOPSYS SENTAURUS ............................................. 56

3.1.1 Simulando a Estrutura ............................................................... 57

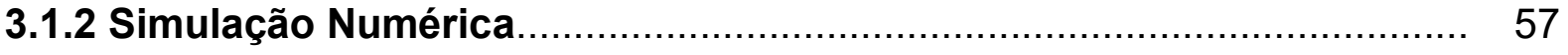


3.2 MODELOS UTILIZADOS NO SENTAURUS ........................................... 58

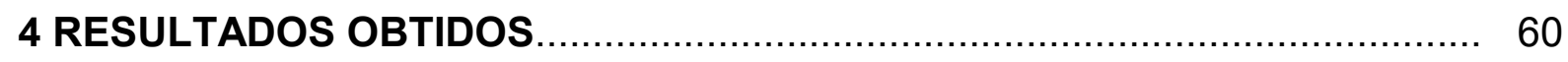

4.1 DIODO PIN CONSIDERANDO UM ESPECTRO DE LUZ

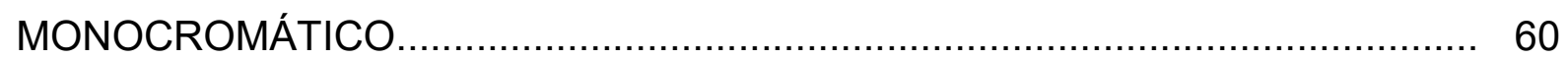

4.2 DIODO PIN OPERANDO COMO CÉLULA SOLAR, ESTRUTURA SEM $\begin{array}{lllllll}\text { PORTA E } & \text { COM ESPESSURA DE SUBSTRATO DE } 80\end{array}$ $\mathrm{nm}$

4.3 DIODO PIN FUNCIONANDO COMO CÉLULA SOLAR CONSIDERANDO ESPESSURA DO SUBSTRATO DE $2 \mu \mathrm{m}$, ESTRUTURA SEM PORTA.

4.4 DISPOSITIVOS PIN SOI CONSIDERANDO A ESPESSURA DO SUBSTRATO DE $2 \mu \mathrm{m}$ COM PORTA.

4.5 A INFLUÊNCIA DA TEMPERATURA QUANTO AO DESEMPENHO DOS DISPOSITIVOS

Conclusões.

REFERÊNCIAS 89

APÊNDICES 96 


\section{INTRODUÇÃO}

A amplitude e expansão de vários segmentos da engenharia elétrica no âmbito da microeletrônica têm apresentado uma gama enorme de dispositivos e formas de utilizá-los em prol da evolução e melhora da vida humana.

A energia solar, por ser uma forma de energia renovável e com grande potencial utilizável em territórios como o do Brasil, com amplas regiões com clima propícias a alta incidência de luz solar, tem ganhado o mercado das tecnologias e projetos sustentáveis. Tendo em vista a necessidade de se encontrar dispositivos capazes de atender tais expectativas, a estudo de um sistema que converte energia obtida a partir do espectro solar em energia elétrica de maneira simples e eficaz é o impulso principal da pesquisa realizada neste trabalho.

De acordo com Foster (1), os primeiros coletores e primeiras placas solares serviram inicialmente como "captadores" e mantenedores de energia para atividades que necessitavam utilizar-se da energia térmica para aumentar e manter a temperatura de vários elementos tais como a água, alimentos e secar peles de animais utilizadas para se proteger de baixas temperaturas. Com os avanços concebidos através dos anos, tornou-se possível também armazenar esta energia para uso posterior, para economia e produção de energia elétrica.

Com foco na produção de energia elétrica a partir da energia solar, as áreas correlatas entre micro e nanoeletrônica foram responsáveis pelo desenvolvimento de dispositivos capazes de tal função com efetividade. Partes fundamentais do estudo, as junções $\mathrm{PN}$, que podem ser denominadas diodos, podem ser fabricadas a partir de lâminas de silício. Estas lâminas têm regiões dopadas com substâncias doadoras de elétrons (tipo $N$ ), a exemplo do fósforo, e com regiões aceitadoras (tipo $P$ ), tal como o boro. A junção destas regiões forma uma região de depleção responsável por posterior formação de portadores de carga (elétrons e lacunas), assim como sua recombinação ocorrida pela atração e repulsão dos portadores e seu fluxo elétrico. Este último, capaz de gerar a corrente efetivamente utilizada por circuitos elétricos. 
A junção pode ser polarizada diretamente, ou seja, o potencial aplicado à região $P$ deve ser superior ao aplicado na região $\mathrm{N}$, ou reversamente.

Junções PN trabalhando de forma inversa ao seu convencional (potencial aplicado à região $\mathrm{P}$ inferior ao da região $\mathrm{N}$ ) são capazes de absorver e converter energia luminosa em eletricidade, fenômeno explanado pelo efeito fotovoltaico, que permite que os fótons incidentes na região de depleção gerem portadores de carga e, consequentemente, corrente. Esta operação pode ser melhorada caso seja utilizado um diodo PIN - abordado por Würfel (2). A princípio um diodo comum, porém a sua região de depleção é aumentada devido à inserção de uma fração de silício intrínseco (ou levemente dopado) entre as regiões $\mathrm{P}$ e N. Obtém-se daí maior geração de corrente e, logo, maior eficiência na utilização do dispositivo como célula solar (3). Percebe-se que o comprimento da região de depleção é muito importante, assim como as medidas de largura, comprimento e espessura do dispositivo para a finalidade discutida e seus tamanhos nano e micrométricos.

Tendo em vista que a tecnologia MOS (Metal-Óxido-Semicondutor) de fabricação convencional de dispositivos eletrônicos sofre com a miniaturização dos circuitos, degradando o seu uso e suas funcionalidades com o aparecimento de vários problemas conhecidos como capacitâncias parasitas e perda de desempenho devido a efeitos de canal curto (4), diversas outras tecnologias foram desenvolvidas.

Entre estas, uma promissora alternativa é a tecnologia SOI (Silicon-onInsulator) ou Silício sobre Isolante, que consiste em aplicar uma camada de óxido de silício entre a região ativa da lâmina, onde ficam os circuitos, e seu substrato. Esta tecnologia garante aos dispositivos melhores características elétricas devido ao isolamento, maior rendimento, reduz perdas ou capacitâncias parasitas e, ao mesmo tempo, permite maior densidade de integração (5).

Quando se fabricam transistores em lâminas SOI, o substrato se mantém inutilizado. Surge, então, a possibilidade de se obter outros dispositivos no próprio substrato desta lâmina. Diodos PIN fabricados no substrato da lâmina, por exemplo, podem trabalhar como fornecedores de energia elétrica para os circuitos existentes na parte ativa da lâmina, tornando-a um sistema autônomo. 
Neste trabalho, será observada a influência que existe da relação entre o comprimento da região intrínseca dos diodos PIN fabricados no substrato das lâminas SOI, sua região de depleção e as características elétricas principais para se obterem as respostas de rendimento e eficiência destes dispositivos no âmbito de atuação como células solares operando em diferentes temperaturas, tendo como base fundamental para dimensionamento dos dispositivos simulados, os cálculos de Fator de Forma e Rendimento de cada dispositivo. Todo o estudo efetuado se baseia em simulações de diodos confeccionados com o auxílio dos aplicativos do SYNOPSYS SENTAURUS (6), as quais foram validadas através de resultados experimentais apresentados na literatura (56) (57). Todos estes pontos e aspectos levantados nesta pesquisa servem para dimensionar e discutir a respeito de sistemas de conversão de energia autônomos e otimizados para o alcance de seu máximo rendimento e eficiência.

\subsection{O PROBLEMA APRESENTADO E SUA JUSTIFICATIVA}

O estudo neste trabalho se deu a partir de pesquisas realizadas anteriormente sobre energia solar (7) e produção de eletricidade (8), com foco especial em meios autônomos e sustentáveis de se obter energia elétrica (9). A busca por meios de geração de energia limpa e renovável tem aumentado no cenário atual (10) (11). Além do mais, o Sol ainda é hoje, uma energia inesgotável e abundante. Deste modo, buscou-se a ideia do estudo de dispositivos PIN fabricado no substrato de lâminas SOI operando como células solares, através de simulações numéricas utilizando a ferramenta SENTAURUS (6). 


\subsection{COLETA E ANÁLISE DE DADOS PARA DESENVOLVER O TEMA}

Após a delimitação do tema-problema e as justificativas, segue-se o momento da elaboração da fundamentação teórica e, consequentemente, o desenvolvimento lógico do estudo.

Primeiro momento: levantamento das bibliografias utilizadas entre outras fontes de conhecimento sobre energia solar para produção de eletricidade, células solares, diodos e diodos PIN, tecnologia SOI a partir de livros, artigos e publicações como teses e dissertações de autores nacionais e internacionais tais como Foster (1), Colinge (4), Bulteel (12), Sze (13), Green (14), Würfel (2).

Segundo momento: as pesquisas foram separadas, selecionadas e utilizadas para dar sustentação ao tema, dando início a elaboração da fundamentação teórica e referências.

Terceiro momento: primeiros contatos com o simulador, em que se fizeram primeiramente simulações de diodos PIN atuando como fotodiodos.

Quarto momento: elaboração do roteiro lógico a se seguir para obtenção dos resultados sobre Fator de Forma e Rendimento a partir das simulações executadas em diodos PIN operando como células solares.

$E$, finalmente, a elaboração das conclusões finais. 


\section{FUNDAMENTAÇÃO TEÓRICA}

Documenta-se aqui todo o conhecimento teórico obtido a partir de pesquisas em livros, artigos internacionais, teses, dissertações e publicações em periódicos para a fundamentação da dissertação apresentada. Serão abordados, neste capítulo, o caminho percorrido desde o estudo da forma obtenção da energia elétrica através da luminosa, os métodos e dispositivos, incluindo a célula solar e os tipos existentes e mais comuns. Será apresentado o modo de funcionamento de uma célula solar feita a partir de uma junção PN e, logo após, serão inseridas as tecnologias PIN e SOI, respectivamente, de forma bem sucinta e objetiva.

\subsection{ENERGIA SOLAR PARA PRODUÇÃO DE ENERGIA ELÉTRICA}

Aldabó (15) discorre que a energia solar é a fonte de energia inesgotável menos poluente conhecida até o momento. Ela se encontra disponível para a humanidade desde que esta povoou a Terra e nunca foi aproveitada de forma tão eficiente quanto as outras formas de energia. Considerando que outras fontes de energia renováveis apresentam desvantagens como o alto custo para obtenção e manutenção dos equipamentos e condições para obtê-las, o sistema de suprimento de energia solar confiável também apresenta certo grau de dificuldades, porém, com menor complexidade que as demais (11).

"O Sol não é uma nova forma de energia. A sua utilização na produção de calor e potência por vários métodos novos constitui uma nova maneira de proporcionar à humanidade os benefícios da energia que tem a idade do mundo" (Bezerra, 1998, p.9) (16).

Palz (17) afirma que o Sol, além de fonte de vida, pode ser a resposta para a questão do abastecimento energético do futuro. Brilhando há bilhões de anos, estima-se que o sol ainda nos privilegiará por alguns bilhões de anos. Descreve que a energia solar que chegou à Terra, em 2004, foi 4000 vezes superior ao que foi consumido de outras fontes de energia. 
Cabirol (18) conta que o Sol é uma esfera com 1.400 .000 quilômetros de diâmetro que irradia energia devido a reações nucleares em cadeia. Uma parte desta energia serve para manter a sua temperatura e o restante é irradiado para o espaço. A temperatura aparente do sol é de aproximadamente 6000 Kelvin e apenas uma parte muito pequena de sua energia chega até a superfície da Terra. Essa energia chega, essencialmente, sob a forma de ondas eletromagnéticas como as utilizadas nas transmissões de rádio ou televisão, porém com comprimentos de ondas mais curtos. A irradiação solar é uma sobreposição de ondas cujos comprimentos variam de 0,25 micrômetros até 4 micrômetros (9). As que se utilizam nos rádios vão de 1 micrômetro a 10 quilômetros (19). Quanto mais curto for o comprimento de onda, maior a sua energia (8).

Palz (17) afirma que aproximadamente $30 \%$ da radiação que atinge a atmosfera terrestre se reflete sem mudança na amplitude de onda. Cerca de $47 \%$ é absorvida pela atmosfera e pela superfície terrestre, provoca um aumento de temperatura e, em seguida, irradia-se novamente para o espaço. Apenas os $23 \%$ restantes penetram no sistema terrestre e passam a ser a força motriz de ventos, correntes, ondas, modelam nosso clima e proporcionam o ciclo da água. Em última instância, retornam ao espaço.

Segundo Aldabó (8), a partir da energia solar, existem dois sistemas para obtenção de energia elétrica: heliotérmico e o fotovoltaico. Neste primeiro, a irradiação proveniente do Sol é convertida em energia calórica utilizada posteriormente em usinas termelétricas para a produção de eletricidade.

Este processo é descrito em quatro etapas (20) tais como a coleta da irradiação, conversão em calor, transporte e armazenamento e por fim conversão em eletricidade.

Para bom aproveitamento da energia heliotérmica é indispensável uma região com alta incidência de irradiação solar direta, além de uma irrelevante ocorrência de nuvens e baixíssima umidade relativa do ar, o que torna este processo muito mais viável nas partes semiáridas do Brasil. 
Pelo sistema fotovoltaico, a conversão ocorre de maneira direta. Para isso, adapta-se um material semicondutor, tal como silício, que permite fluxo eletrônico quando estimulado pela radiação. As células fotovoltaicas, também denominadas células solares, possuem ao menos duas camadas de semicondutores, que dão origem a uma junção eletrônica.

Assim que o espectro solar incide na região da junção, o campo elétrico existente no dispositivo dá início a um fluxo de energia na forma de corrente contínua. O fluxo de energia elétrica depende diretamente da intensidade da luz aplicada sobre a célula.

Os sistemas fotovoltaicos conectados à rede de fornecimento de energia elétrica representaram, em âmbito mundial nos últimos anos, a tecnologia de geração com maior crescimento (8).

\subsubsection{O espectro Solar}

Fundamental na explanação de cada aplicação da energia luminosa, o espectro solar compreende todos os tipos de luz e radiações existentes.

Nesta pesquisa, o foco e aplicações se darão através do espectro eletromagnético da luz ou espectro visível. Segue figura 1, representando de forma linear cada tipo de onda e os respectivos comprimentos de ocorrência. 
Figura 1 - Espectro total e espectro visível ou eletromagnético.

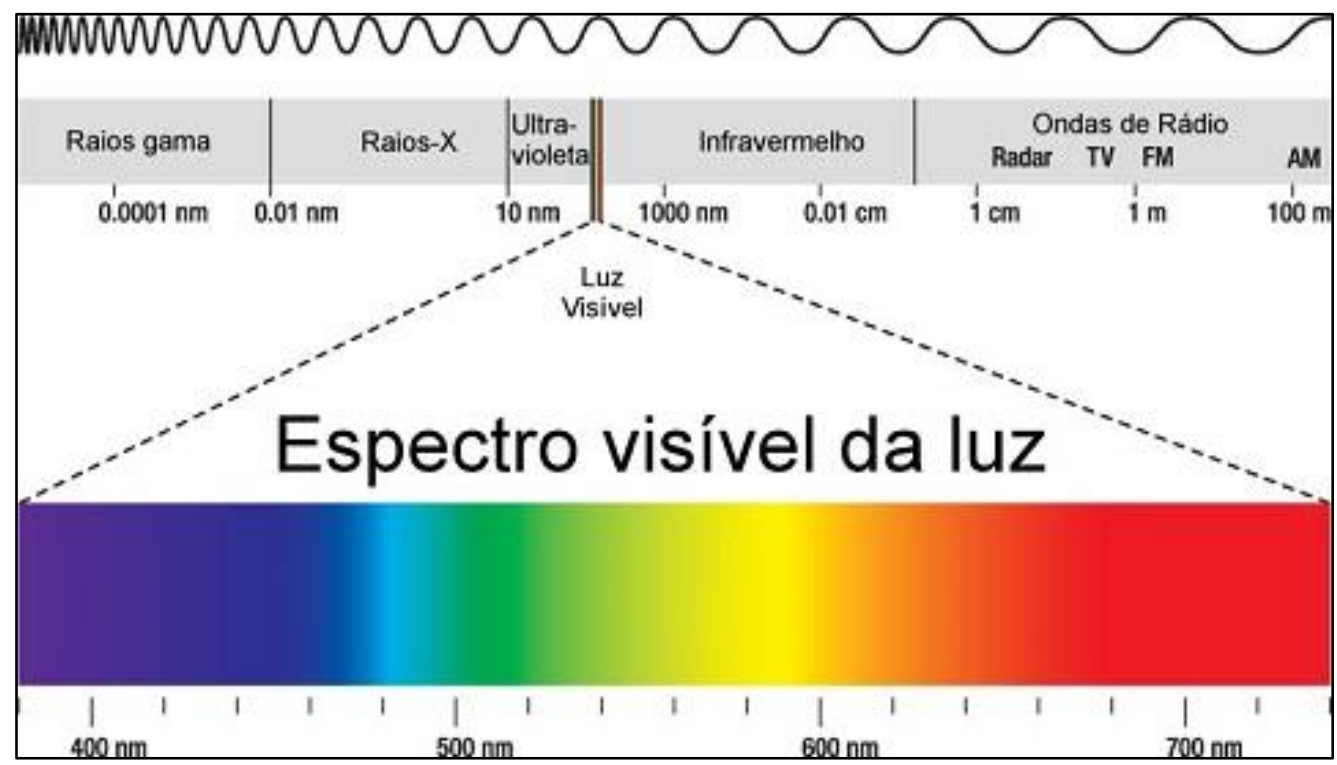

Fonte: (21). Disponível em http://www.antonine-education.co.uk, acesso em janeiro de 2017.

A potência de cada tipo de onda expressa acima é inversamente proporcional ao seu comprimento (21), sendo raios gama a radiação mais potente e a de menor comprimento e ondas de rádio $\mathrm{AM}$ as menos potentes, porém as maiores. $\mathrm{O}$ Sol irradia ondas eletromagnéticas de seu corpo escuro. Já foram citadas suas principais características, porém é importante ter como conhecimento o quanto de sua energia chega a Terra e se torna disponível para uso em uma célula solar, por exemplo.

A NASA caracterizou e nomeou o espectro que chega à atmosfera da Terra como espectro terrestre, recebendo a denominação de AM0 (22). Porém, a densidade de potência desse espectro que chega à superfície terrestre ou de um dispositivo exposto a céu aberto diminui devido aos gases atmosféricos e à reflexão causada pelas nuvens. Estabelecido para células solares, o espectro AM1.5G (Espectro Global ou total) (22), considera densidade de potência de $1000 \mathrm{~W} / \mathrm{m}^{2}$ que corresponde à máxima potência do espectro que consegue incidir em uma célula solar. Este foi o modelo inserido e utilizado acerca das simulações e demais estudos da pesquisa. Para células fotovoltaicas com concentradores de luz, que conseguem absorver apenas a incidência direta de energia, é utilizado o espectro AM1.5D (Espectro Direto), que possui potência de $775 \mathrm{~W} / \mathrm{m}^{2}$, sendo que potências superiores a esta são dispersadas pela difusão, fenômeno esse que tem ocorrência quando o 
espectro se choca com certas partículas dentro da atmosfera e se difunde em várias direções. Uma parte é difundida pelo ar, principalmente a luz azul, uma boa parte pelas nuvens, névoa seca, que difunde principalmente a vermelha, e por fim a luz amarela que é difundida por partículas de poeira. As figuras 2 e 3 ilustram o esquema de captação da energia destes espectros e a densidade de potência que cada um gera dentro de cada comprimento de onda.

Figura 2 - Incidência da radiação solar relacionando absorção, reflexão e difusão.

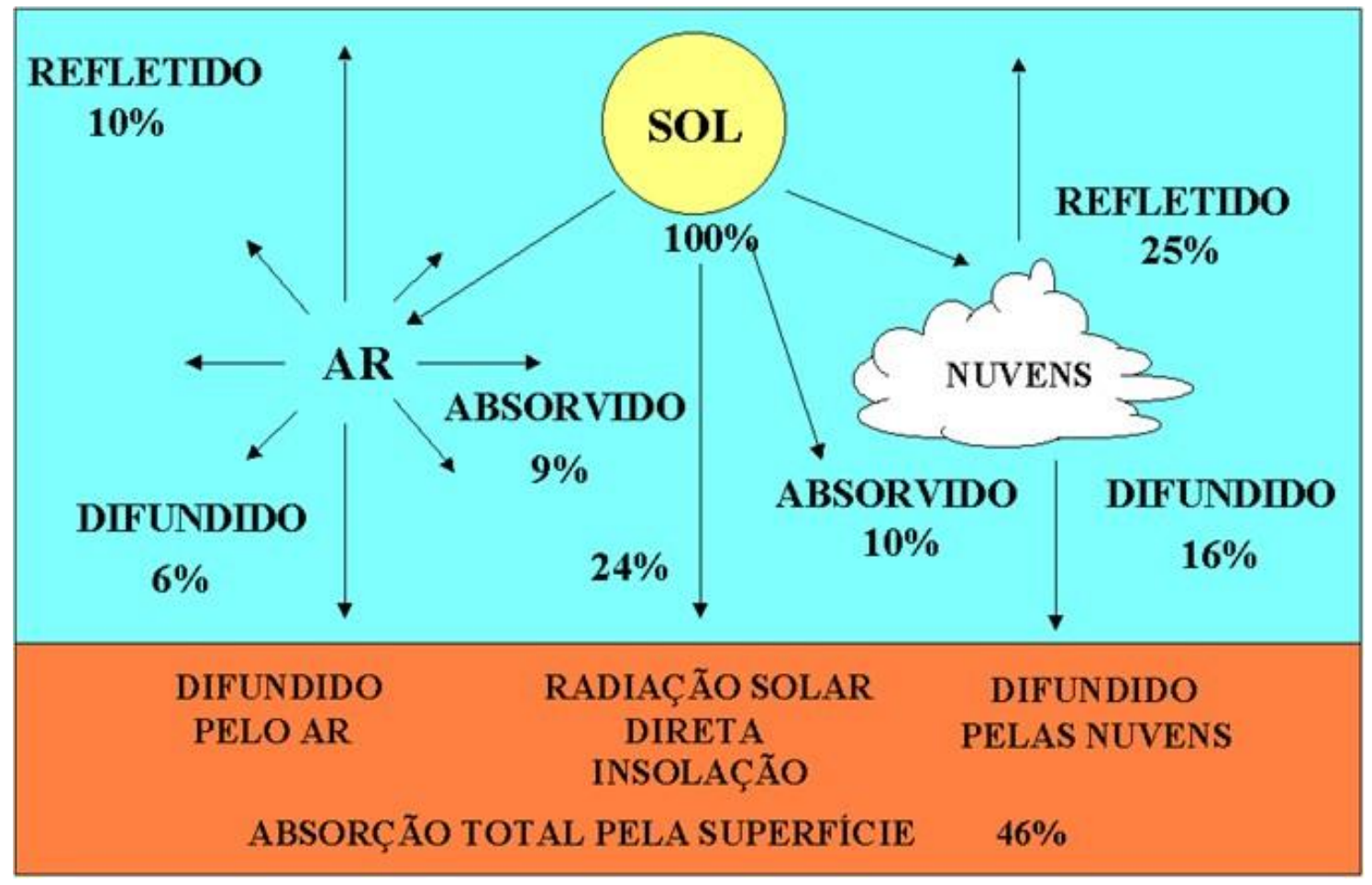

Fonte: Adaptado de (23).

A figura 2 é uma demonstração da radiação solar atingindo a superfície da terra e o montante que pode ser absorvido por ela ou por algum objeto/dispositivo que ali esteja situado e o que acontece quanto à atmosfera. 
Figura 3 - Gráfico da densidade de potência em função do comprimento de onda a partir dos espectros AM1.5G e AM1.5D e a difusão do espectro (Diff).

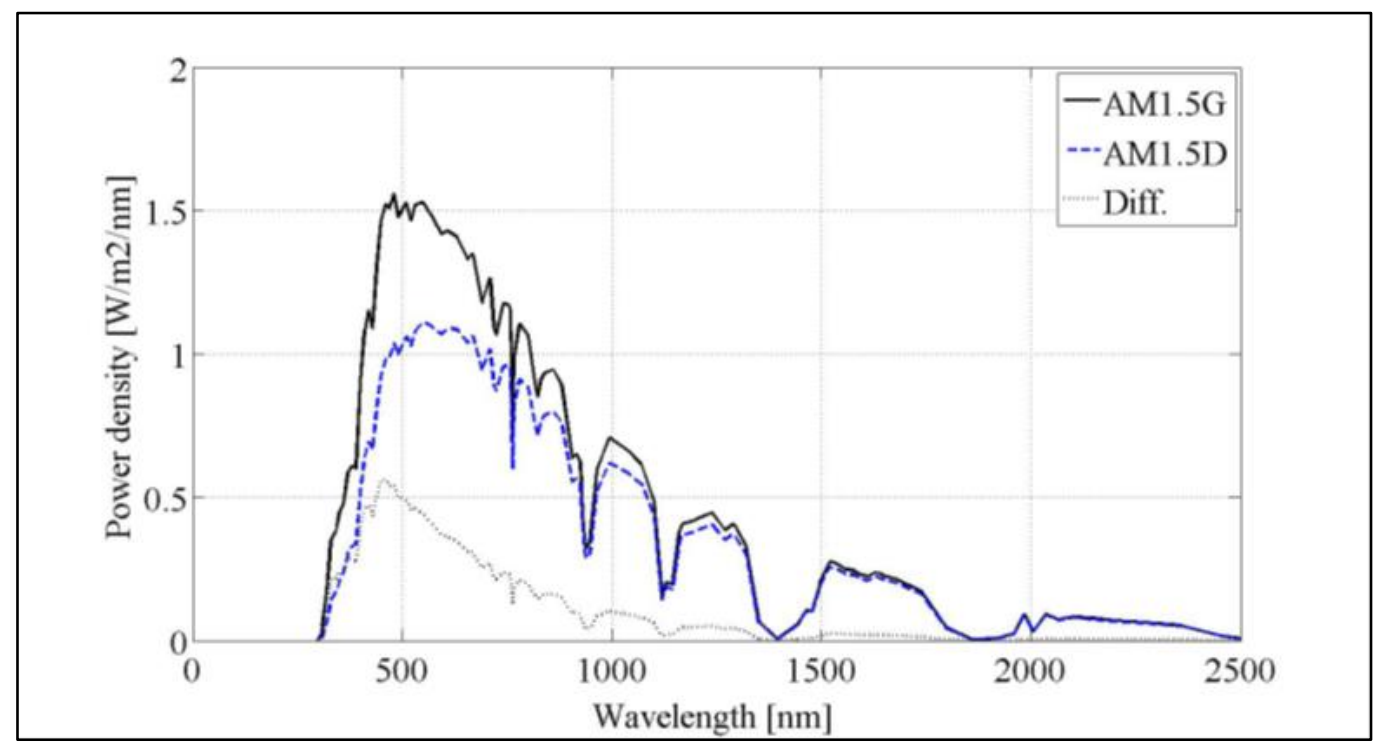

Fonte: (13), p.116.

Dentre outras características existentes no espectro visível, temos uma relação da incidência de fótons numa superfície de silício com o seu comprimento de onda, que se denomina comprimento de absorção. Esta relação compreende a capacidade que o material tem para absorver energia de fótons incidentes, de acordo com o comprimento da onda que incide neste material. Na figura 4, é apresentada a curva do comprimento de absorção dos fótons no silício (absorption length in silicon) em função do comprimento de onda (wavelength). 
Figura 4 - Gráfico do comprimento de absorção em função do comprimento de onda do silício.

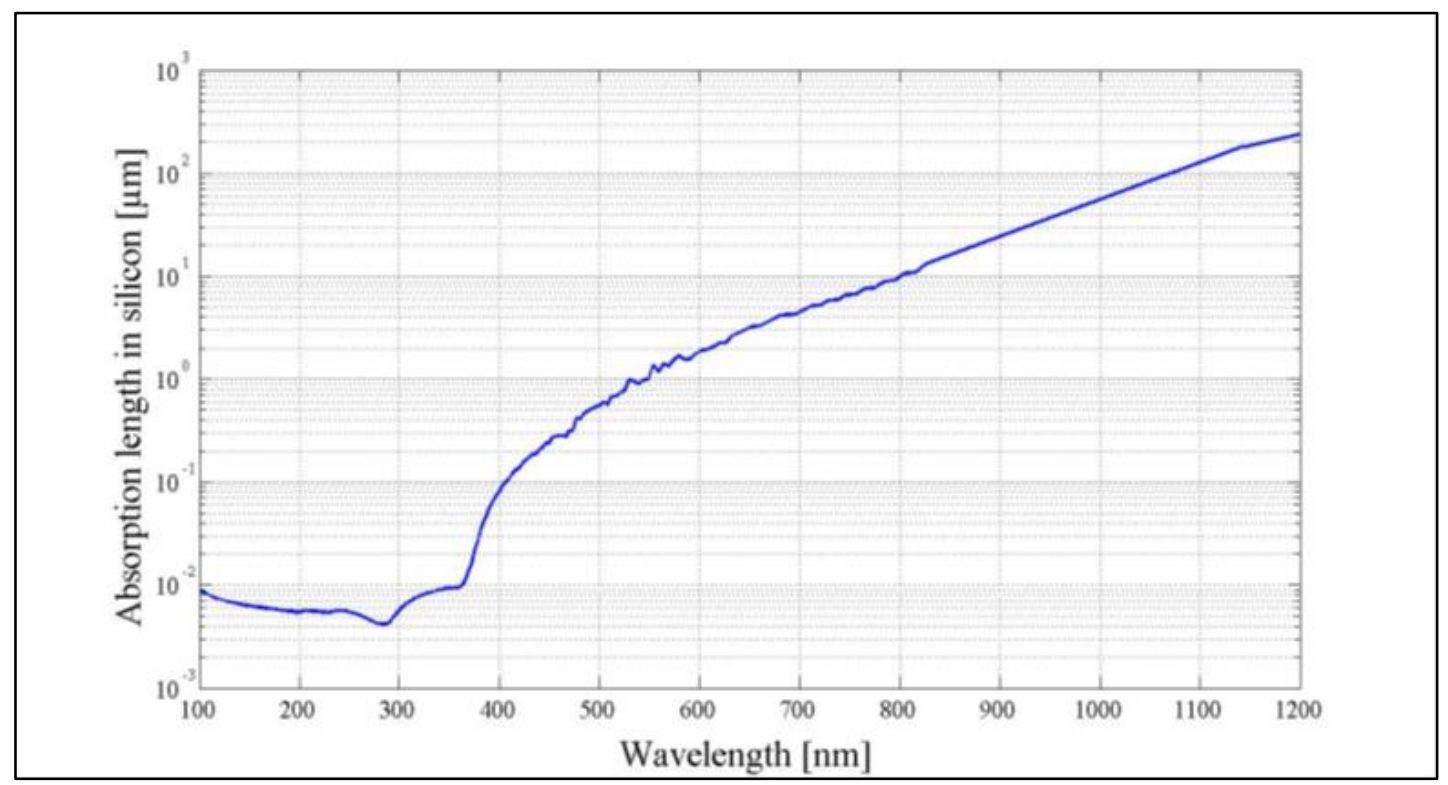

Fonte: (12), 2011

Nota-se, na figura 4, que fótons com comprimentos de onda de até $400 \mathrm{~nm}$ necessitam de uma camada de silício de espessura de $100 \mathrm{~nm}$ para serem absorvidos, isso caracteriza o comprimento de absorção que tem uma queda igual ao inverso da energia liberada pelos fótons. Para fótons com maiores comprimentos de onda, são necessárias camadas de silício mais espessas, de forma que para um comprimento de onda de $1200 \mathrm{~nm}$, são necessárias camadas de silício com espessura da ordem de $200 \mu \mathrm{m}$. Para camada de silício com espessuras inferiores à necessária, há perda de capacidade de absorção, ou seja, apenas parte dos fótons será absorvida.

Outro comportamento importante a se observar é a relação da potência que se obtém ao longo da profundidade da camada de silício para diferentes comprimentos de ondas eletromagnéticas. A figura 5 auxilia na compreensão desse fato, mostrando o que acontece com a energia incidente no silício à medida que a luz penetra no material. 
Figura 5 - Perda de intensidade da incidência de luz no silício em função de sua profundidade.

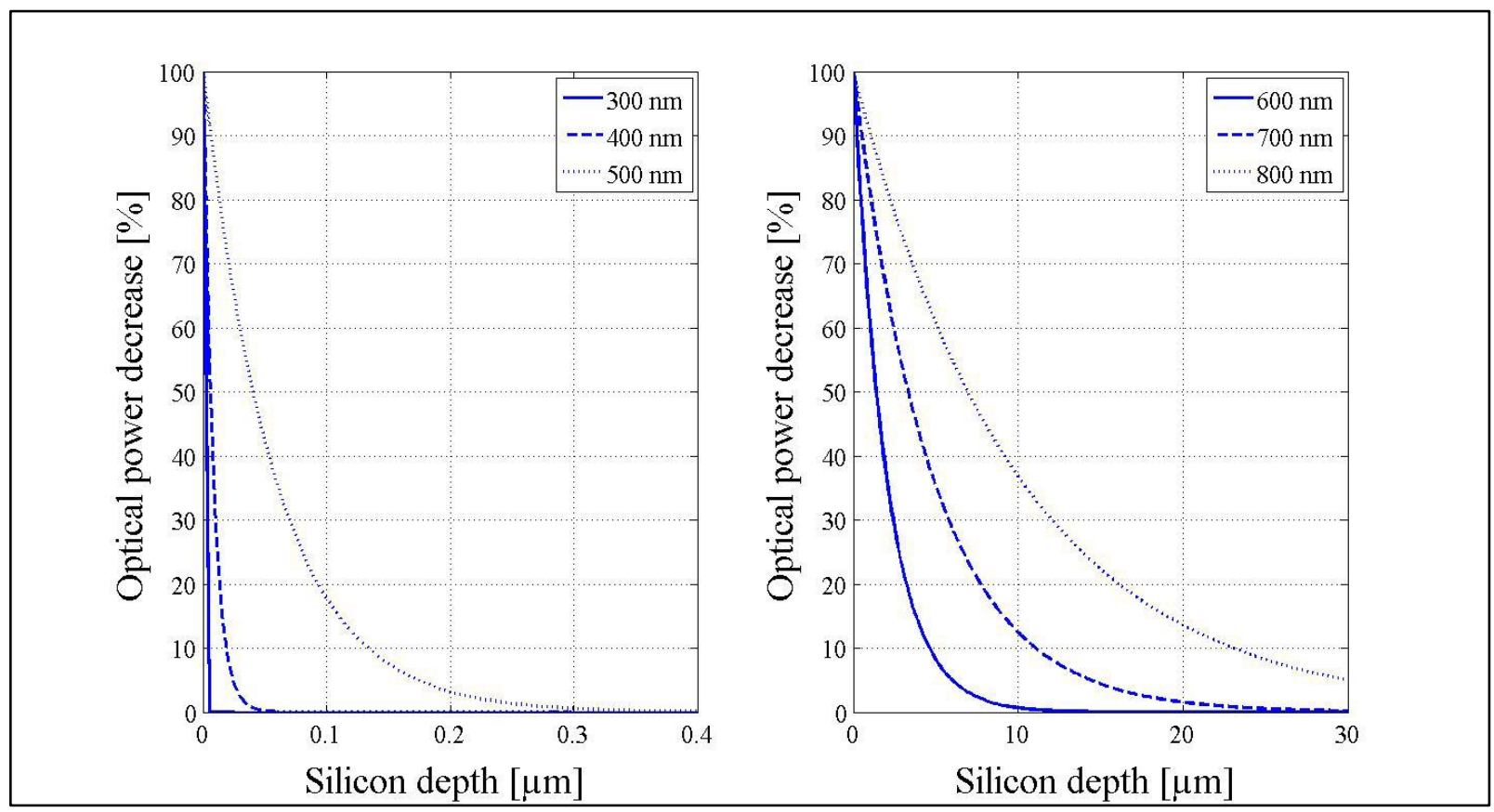

Fonte: (12), p.11.

Percebe-se que, em comprimentos de onda menor, a energia é quase toda consumida ainda na superfície, alcançando cerca de 300 nanômetros de profundidade para um comprimento de onda de $500 \mathrm{~nm}$. Quando se compara isto com comprimentos de onda maiores que $500 \mathrm{~nm}$, a profundidade que se consegue chegar até que se consuma toda a energia da radiação se situa em dezenas de micrômetros, superior aos $30 \mu \mathrm{m}$ quando se trata de $800 \mathrm{~nm}$ de comprimento de onda.

\subsection{SEMICONDUTORES}

Boylestad e Nashelsky (24) dissertam que semicondutor é o que se situa entre condutor e isolante. Condutor é aquele que, através de uma diferença de potencial aplicada em seus terminais a partir de uma fonte tensão, consegue manter um fluxo elétrico contínuo. $E$ isolante é aquele que oferece baixíssima condutividade quando é submetido a uma fonte de tensão. Conclui-se que semicondutor é um material que se encontra num ponto médio de condutividade. 
Dentre os semicondutores mais importantes, estão o germânio $(\mathrm{Ge})$ e o silício (Si), que podem ser encontrados facilmente na natureza e possuem altos níveis de pureza após sua obtenção industrial. Estes materiais tem a capacidade de alteração radical de suas características, por um processo chamado de dopagem. Quando se mantém o material o mais puro possível, ele é denominado intrínseco.

Outra das qualidades destes materiais diz respeito à estrutura atômica precisa e periódica formando conjuntos chamados de cristais (24). O átomo de germânio tem 32 elétrons que orbitam o núcleo, enquanto o silício possui 14. Em ambos os casos, existem 4 elétrons na camada mais externa do átomo (camada de valência) que se ligam de forma covalente com elétrons presentes na camada de valência de átomos vizinhos, ou seja, há compartilhamento de elétrons entre átomos adjacentes. Como se encontram mais distantes do núcleo, a liberação de um desses quatro elétrons de sua ligação covalente exige menor potencial de ionização.

Os elétrons de valência podem absorver energia suficiente de fatores naturais, quebrar a ligação covalente e se tornarem "portadores de carga livres". O termo livre descreve o movimento do elétron, sendo bastante sensível a campos elétricos como os que são estabelecidos por fontes de tensão. Os fatores naturais para os elétrons obterem energia envolvem a incidência da luz em forma de fótons ou energia térmica do meio.

Em temperatura ambiente, o silício intrínseco, em seu estado de maior pureza, possui por volta de $1,5 \times 10^{10}$ portadores livres por centímetro cúbico. Neste estado intrínseco, ele é considerado mal condutor. A partir da dopagem, o silício se torna extrínseco o que aumenta sua condutividade.

É importante ressaltar que, para calcular potencial elétrico de um dispositivo, toma-se como base seu potencial de Fermi $\left(\Phi_{\mathrm{F}}\right)$, o qual torna possível a distinção das bandas de energia de um material $P$, um $\mathrm{N}$ e um intrínseco e pode ser representado graficamente. $O$ potencial de Fermi-Dirac é apresentado como uma forma de se estimar quais estados energéticos de um semicondutor estão ocupados e como funcionasse dá a distribuição dos elétrons e lacunas do semicondutor (25). O nível de Fermi pode ser representado da seguinte forma, como consta na figura 6 : 
Figura 6 - Esquema de banda de energia com nível de Fermi para semicondutor intrínseco.

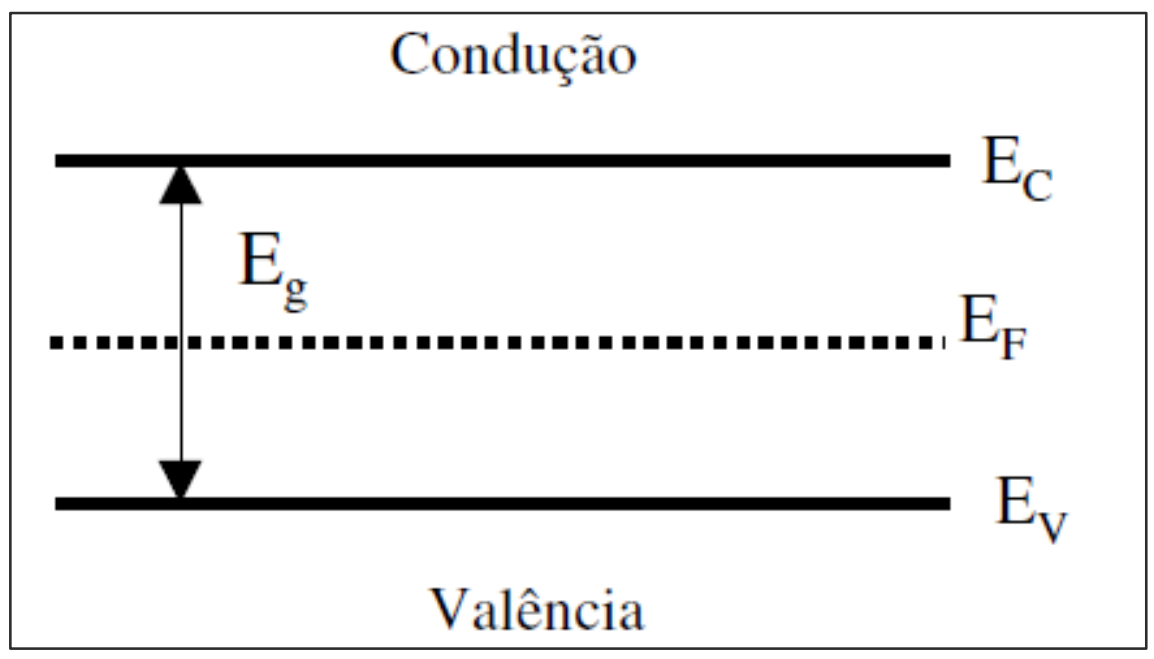

Fonte: Adaptado de SZE (13).

O esquema acima deixa explícitos os conceitos de energia existentes no diagrama de bandas a começar pelo $\mathrm{E}_{C}$ que é o nível de energia necessário para que o portador passe a conduzir. Ev é o nível de energia da banda de valência. Os portadores que não possuem energia para conduzir ficam lá. No caso do semicondutor ser extrínseco o nível de energia Fermi $E_{F}$ fica exatamente na metade entre condução e valência, e nunca há portador nessa região. Ele indica a probabilidade de um portador estar na banda de valência ou de condução. $E_{G}$ é o Energy Gap ou nível de energia de banda proibida É a partir dele que se define a quantidade de energia necessária para um portador sair da valência e chegar à condução. É possível calcular o potencial de Fermi que um semicondutor tem em relação à temperatura que é exposto conforme é mostrado na equação a seguir:

$$
\emptyset F p=\frac{K \cdot T}{q} \cdot \ln \left(\frac{N A}{n i}\right)
$$

Representado acima temos uma equação que calcula o potencial de Fermi de um semicondutor com impureza aceitadora $\mathrm{N}_{\mathrm{A}}$, em que temos a constante de boltzmann $\mathrm{K}$, a carga do elétron dada por $q$, a temperatura $T$ e concentração intrínseca de portadores ni. 
No caso de um fotodetector ou de uma célula solar, quando um fóton é absorvido pelo semicondutor, ele fornece energia a rede cristalina. Assim, há a formação de um par elétron-lacuna, momento em que a condução elétrica tem origem. No caso de um dispositivo emissor de luz como um diodo LED, há a emissão de um fóton no momento em um elétron se recombina a uma lacuna na camada de valência (23).

Ainda em acordo com os escritos de Aldabó (8), a energia obtida a partir de agitação térmica pode fazer com que o elétron "escape" da superfície do condutor, configurando assim uma emissão termoiônica de elétrons de metais. Mesmo sem agitação térmica suficiente, em baixas temperaturas, os elétrons podem adquirir energia suficiente para sair de um condutor se este for incidido por luz de comprimento de onda adequadamente pequeno (9). A este efeito deu-se o nome de fotoelétrico, que fora analisado por Hertz em meados de 1887 (19).

Verifica-se que a velocidade de emissão dos elétrons independe da intensidade da luz que atinge o condutor, mas depende diretamente do comprimento da onda de luz, o qual é abordado logo em seguida juntamente com as propriedades óticas (26). É necessário afirmar que a corrente gerada pelo efeito fotoelétrico aumenta com a intensidade da luz, pois isso gera um aumento na quantidade de elétrons emitidos.

Este efeito tem relação direta com modelos de condução de eletricidade. Possui forte semelhança com o efeito fotovoltaico em aspectos físicos, porém este segundo trata exclusivamente da conversão direta de energia solar em corrente elétrica contínua (8). 


\subsubsection{Propriedades Óticas nos Semicondutores}

As propriedades óticas são importantes quando se trata de caracterizar as bandas de energia de um semicondutor visando seu funcionamento como fotodetector ou célula solar.

Transições eletrônicas entre bandas de energia podem ser induzidas por fótons. As propriedades óticas também podem ser utilizadas para se estudar vibrações na rede cristalina pelo espectro de fônons (13).

Fônons são um conjunto de quase-partículas que podem ocorrer em uma estrutura cristalina rígida, assim como o silício, que servem para designar um quantum de vibração, ou estado enérgico gerado por vibrações (27).

Esta pesquisa tem como prioridade focar a análise das propriedades óticas dos semicondutores a partir do conhecimento dos fótons e sua unidade de energia. Tem se que, em uma análise óptica, o coeficiente de transmissão $T$ e o coeficiente de reflexão $R$ são duas das principais grandezas dimensionadas. Com incidência normal dos raios solares eles podem ser obtidos através de:

$$
\begin{gathered}
T=\frac{\left(1-R^{2}\right) \exp \left(-\frac{4 \pi x}{\lambda}\right)}{1-R^{2} \exp \left(-\frac{8 \pi x}{\lambda}\right)}(2) \\
R=\frac{(1-\tilde{\mathrm{n}})^{2}+k^{2}}{(1+\tilde{\mathrm{n}})^{2}+k^{2}}(3)
\end{gathered}
$$

onde $\lambda$ é o comprimento de onda, $\tilde{n}$ é o índice de refração, $k$ é a constante de absorção e $X$ é a espessura da amostra de semicondutor utilizada. $\mathrm{O}$ coeficiente $\alpha$ de absorção por unidade de área é encontrado da seguinte forma:

$$
\alpha=\frac{4 \pi \mathrm{k}}{\lambda}(4)
$$


Analisando os dados a partir da reflexão e da transmissão em relação ao comprimento de onda em incidência solar normal ou observando estes mesmos dados para diferentes ângulos de incidência, deve-se obter $\tilde{n}$ e $k$ e estes podem ser relacionados diretamente à transição que ocorre entre as bandas de energia, assim como na figura abaixo:

Figura 7 - Esquema da dispersão e os tipos de transição que a energia sofre.

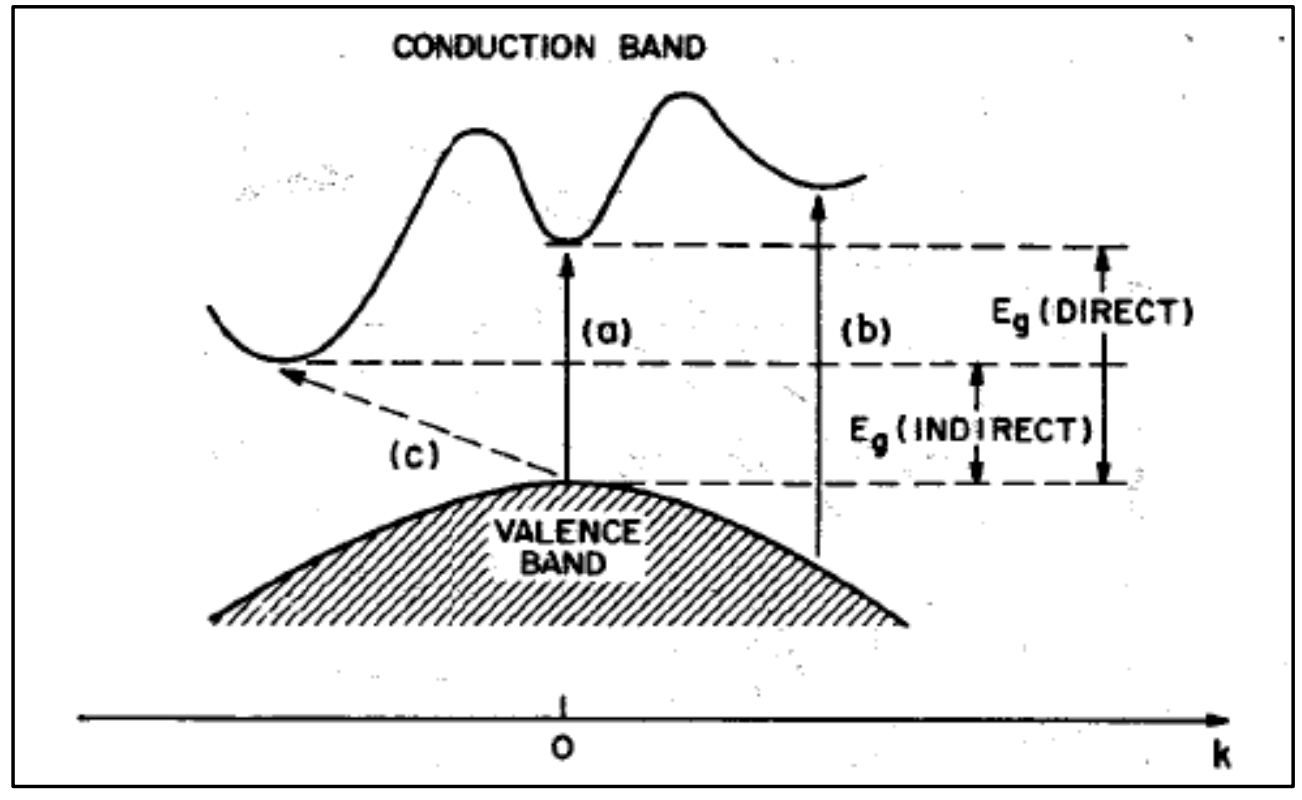

Fonte: SZE (13).

A figura 7 exemplifica a dispersão do espectro de luz em relação ao semicondutor quando a absorção se aproxima de seu limiar. Nesta figura, ainda podem ser identificadas transições diretas e indiretas, que são induzidas diretamente pelos fótons que ocorrem entre as bandas de energia. A partir delas são determinados os níveis de energia $A$ diferença entre as duas transições é que a direta ocorre a partir do fóton (energia ótica) quando este está próximo ao limiar de absorção pelo material, enquanto as indiretas são oriundas dos fônons, ou seja são as transições eletrônicas que ocorrem a partir da excitação de portadores por vibrações. O seu coeficiente pode ser calculado em outra instância:

$$
\alpha \approx(h v-E g)^{\gamma}(5)
$$

em que $h v$ indica a energia do fóton liberado, $E g$ é a energia de faixa proibida e $\gamma$ é uma constante que depende do tipo de transição energética que ocorre. Adentrando 
a energia do fóton, temos $h$ que é a constante de Planck e $v$ é a velocidade da onda incidente (28).

É relevante informar que a origem da constante de Planck advém de um experimento com molas de corpo negro e sua oscilação, desenvolvido pelo físico alemão Max Planck. Ao aumentar a energia das molas através da radiação, Max percebeu a amplitude desta oscilação aumentava. A partir daí ele definiu que esses osciladores deveriam possuir um valor padrão de energia, múltiplo de um valor mínimo. Este valor mínimo de energia, que tanto pode ser absorvida quanto emitida, ficou conhecida como um quantum de energia. Assim, temos que o valor deste quantum é igual a: $h=6,63 \times 10^{-34} \mathrm{~J} . \mathrm{s}$ (Joule por segundo). E a equação que determina a energia de um fóton pode ser representada assim:

$E=h f$, e em caso de se utilizar a velocidade da onda, temos que $E=h v / \lambda$, sendo $f$ a frequência. A velocidade da onda é conseguida de acordo com $v=\lambda f$ e, consequentemente, a frequência será igual a $f=v / \lambda$, logo, a energia dos fótons pode ser mensurada em elétrons volts $(\mathrm{eV})$ e em Joules $(\mathrm{J})$, sendo que $1 \mathrm{eV}=1,6 \times 10^{-19} \mathrm{~J}$.

\subsubsection{Eficiência Quântica}

Eficiência quântica é uma característica/propriedade de ganho de fótoncorrente em dispositivos em que existe a ocorrência do efeito fotovoltaico e tem relação ao quantum de energia. A eficiência quântica total $\left(E Q_{T}\right)$, como é formalmente apresentada em (13), corresponde à razão entre corrente de anodo realmente gerada por fótons $\left(\mathrm{I}_{\mathrm{FG}}\right)$ e a máxima corrente que poderia ter sido gerada se todos os fótons tivessem sido convertidos em fotoportadores, representada na seguinte equação:

$$
E Q_{T}=\frac{I_{F G}}{I_{F G(\max )}}(6)
$$

A partir dela, é definida a densidade de portadores de carga (elétrons) utilizados em um fluxo elétrico que é concebido por cada fóton absorvido por um dispositivo. A partir daí, através do campo gerado dentro do semicondutor tem-se 
uma corrente foto-geradora $(I P)$ que flui entre os eletrodos e pode ser representada pela seguinte equação (29):

$$
I p=q\left(\eta \frac{P o p t}{h v}\right)\left(\frac{\mu n \cdot \tau \cdot \xi}{L}\right)
$$

Onde: $q$ é a carga do elétron, $\eta$ é a eficiência, Popt é a potência luminosa incidente, hv é a energia do fóton, $\mu$ n é a mobilidade do semicondutor tipo $n, \tau$ é o tempo de vida do portador de carga, $\xi$ é a intensidade do campo elétrico, e L é o comprimento total do dispositivo. Consequentemente à obtenção da foto-corrente, é possível calcular o ganho pela eficiência quântica de acordo com a seguinte equação:

$$
\text { Ganho }=\frac{I p}{I p h}=\frac{\mu \cdot \tau \cdot \xi}{L}=\frac{\tau}{t r}(8)
$$

Na qual $I p h=q\left(\eta \frac{\text { Popt }}{h v}\right)$ é a corrente primária gerada. Este ganho ocorre em dispositivos semicondutores (25). A eficiência quântica é, entre outras palavras, o número de pares elétrons-lacunas que surgem quando há incidência de um fóton, tendo como suas características principais a corrente foto-gerada pela absorção da potência ótica (Popt) num determinado comprimento de onda. O conceito de eficiência quântica pode ser aplicado também na célula solar e ajuda a explicar o efeito fotovoltaico e o conceito de rendimento delas. Se cada fóton gerasse um par elétron-lacuna, a eficiência quântica chegaria a $100 \%$, porém há três motivos pelos quais isto não ocorre: os semicondutores possuem uma área fotossensível, ou seja, a própria superfície deles reflete parte da radiação e absorvem outra parte. Para evitar esse problema, eles podem possuir coberturas antirreflexo. Pelas reflexões e efeito de transmissão natural da energia ótica em um semicondutor. Estes efeitos se relacionam diretamente com a potência total incidida e a potência absorvida e, por fim, os efeitos de recombinação que impedem que os portadores gerados por fótons cheguem aos terminais de um dispositivo semicondutor. 


\subsubsection{Efeito Fotovoltaico}

É a conversão de energia fotônica para portadores de carga e consequentemente que participarão do fluxo ou corrente elétrica. Este efeito, que ocorre quando há incidência de luz (fótons) em um semicondutor, tem relação direta com a geração de portadores de carga e sua mobilidade ou transporte. Pode ser definida, então, como o volume de pares elétron-lacuna gerados em um dispositivo de silício por fótons que liberam energia (30). Como já mencionado, a energia dos fótons é adquirida da difusão de energia ótica absorvida quando esta entra em contato com a superfície do semicondutor.

A geração de portadores de carga que ocorre com o efeito fotovoltaico é denominada de geração irradiante (G:I) ou ótica e consiste na excitação do elétron saindo da banda de valência para condução através da absorção de um fóton com energia suficientemente maior que a descrita pela banda proibida (bandgap) (31). Este processo é explicado pelas características óticas de um semicondutor no que diz respeito à dispersão de energia ótica incidida em forma de fótons com quantidade de energia variada. Por isso, os elétrons podem receber excitação de um fóton com pouca ou muita energia, o que faz com que nem todos os elétrons consigam energia suficiente para alcançar a banda de condução. 


\subsection{CÉLULAS SOLARES}

Células solares fotovoltaicas são dispositivos em estado sólido produzidos com a finalidade de converter energia luminosa emanada do sol em corrente elétrica pelo fenômeno denominado efeito fotovoltaico (32).

A partir do efeito fotovoltaico, já descrito neste trabalho, tem se que diversos parâmetros são fundamentais no desempenho das células solares. Esta eficiência pode ser avaliada através de diversas figuras de mérito como o rendimento e o fator de forma os quais são descritos nos tópicos a seguir.

\subsubsection{Rendimento}

O rendimento, ou eficiência de operação de uma célula fotovoltaica, é determinado por sua máxima potência elétrica obtida na saída do circuito (Pmáx) dividido pela potência fornecida pela fonte de luz ou potência de entrada, que é dada pela equação (8):

$$
\eta=\frac{\text { Pmáx }=V \text { máx } \times \text { Imáx }}{\text { Pin=Área }\left(m^{2}\right) \times 1000\left(\frac{m W}{m^{2}}\right)} \times 100 \%(9)
$$

onde Pmáx é obtida através do produto da corrente máxima (Imáx) pela tensão máxima (Vmáx) que o circuito apresenta. $O$ valor da potência máxima é dividido pela potência de entrada ou fornecida, que é calculada com base na área da superfície em que ela incide. Considera-se a densidade de potência incidente igual a $1000\left(\mathrm{~mW} / \mathrm{m}^{2}\right)$ de acordo com estabelecimento da NASA (22). O valor obtido desta relação é multiplicado por 100 para que se obtenha a resposta em porcentagem, dando assim uma ótica analítica ao resultado. Se após os cálculos, a resposta for, por exemplo, $4 \%$, isso significa que a célula solar em questão converte $4 \%$ da luz incidente em energia elétrica. A letra $\eta$ simboliza o rendimento.

Existem fatores que influenciam o rendimento de uma célula fotovoltaica, tais como perdas causadas pela resistência interna, perdas por recombinação, eficiência termodinâmica e perdas por reflexão da radiação (33). 


\subsubsection{Fator de Forma}

Na figura 8 é apresentada, no eixo vertical, a densidade de corrente $(\mathrm{J})$ de uma célula solar, em função da diferença de potencial aplicada aos seus terminais. Neste caso, é apresentada a densidade de corrente, uma vez que a corrente dos dispositivos está normalizada pela largura W. Na figura são definidas as áreas de dois retângulos, um deles formado pela tensão máxima e corrente máxima do circuito, $\mathrm{V}_{\text {máx }}$ e $\mathrm{I}_{\text {máx }}$, respectivamente, e o formado pela tensão de circuito aberto $\left(V_{\mathrm{OC}}\right)$ e pela corrente de curto-circuito $\mathrm{I}_{\mathrm{SC}}$, ou $\mathrm{J}_{\mathrm{SC}}$. Voc é extraída a partir do valor de tensão para o qual a corrente que flui através do dispositivo é nula. Isc, por outro lado, corresponde ao menor valor que se obtém de corrente, a qual é extraída no ponto de tensão mais negativa utilizada na experiência.

O Fator de Forma (FF - Fill Factor) é definido, simplesmente, pela razão entre as áreas formadas pelos retângulos dados por Vmáx; Imáx e $V_{O C}$; Isc, como descrito na equação (12):

$$
F F=\frac{\mathrm{V}_{\text {máx }} \mathrm{I}_{\text {máx }}}{\mathrm{V}_{\mathrm{OC}_{\times}} \mathrm{I}_{\mathrm{SC}}}(10)
$$

A partir desta equação obtém-se um valor entre 0 e 1 , devido ao fato de se tratar da razão de áreas. Observa-se ainda, através da figura 8 que, quanto mais a curva do Fator de Forma, se aproximar do retângulo externo (reproduzido pelas linhas tracejadas formada por $\mathrm{I}_{\mathrm{SC}} \mathrm{e} \mathrm{V}_{\mathrm{OC}}$ ) seu valor estará mais próximo de um. Nas figuras 8 e 9 , são apresentados gráficos relacionando os parâmetros do fator de forma. 
Figura 8 - Curva relacionando as características elétricas que originam o Fator de Forma.

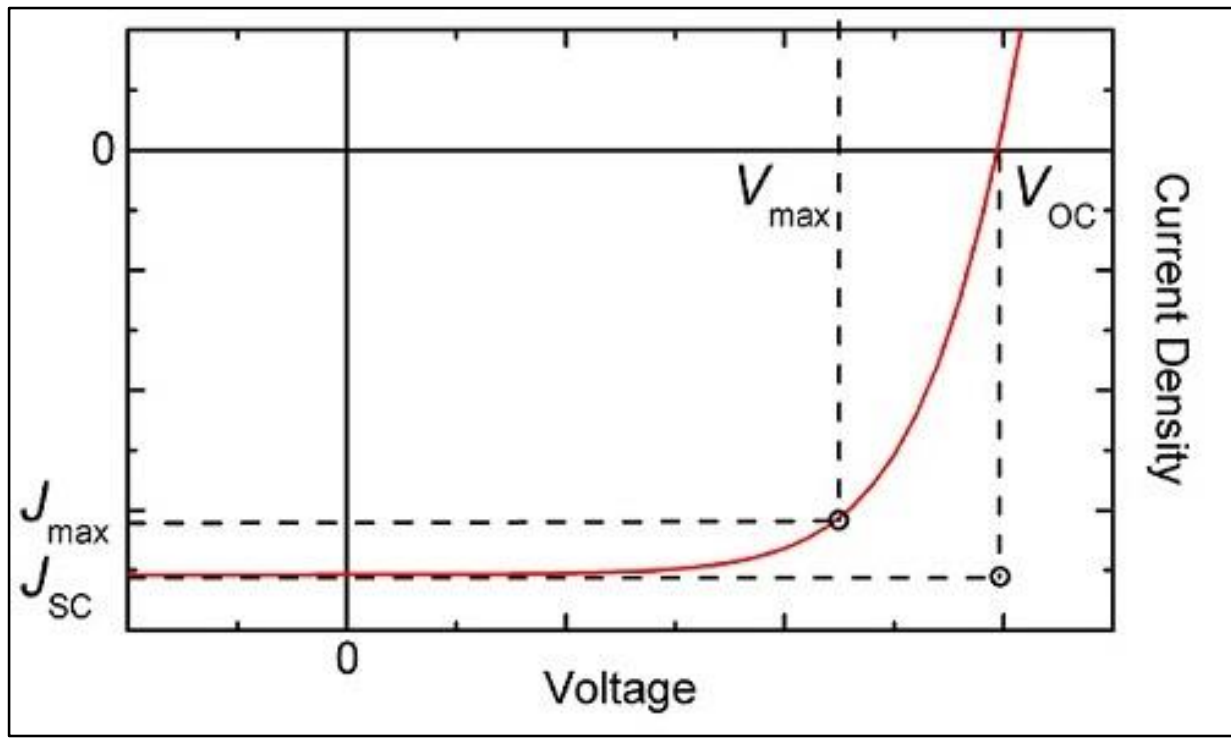

Fonte: (12), 2011.

A figura 9 representa a área formada pela razão entre $\mathrm{I}_{\mathrm{SC}} \mathrm{e} \mathrm{V}_{\mathrm{OC}}$ de forma mais clara indicando a região onde se encontra o FF.

Figura 9 - Representação gráfica da área formada pelo fator de forma no quarto quadrante.

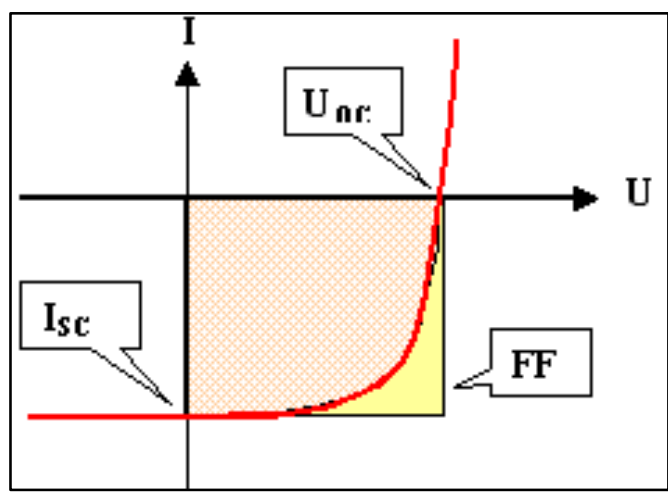

Fonte: Adaptado de (12).

A área preenchida em pontos laranja corresponde ao fator de forma. Quanto menor a área amarelada, mais próximo de 1 esse fator será. 


\subsubsection{Tipos de células solares}

A tecnologia que domina o mercado das células solares, atualmente com cerca de $95 \%$ de participação, é a fabricada a partir de silício cristalino. Resultados práticos obtidos com sua utilização e abordados na referência (15) demonstram que painéis, ou placas solares formadas por ele, têm um rendimento médio entre $13 \mathrm{e}$ $17 \%$ efetivos em termos de conversão de energia. Apesar de não serem as que apresentam maior rendimento, sua principal vantagem é sua acessibilidade em relação à obtenção dos materiais e custo final de fabricação, tendo em vista que o silício cristalino é um material em abundância. Esta tecnologia é amplamente conhecida e utilizada principalmente pela indústria eletrônica, sendo que há casos nos quais dispositivos melhorados apresentam até $20 \%$ de rendimento (9). Camadas finas de silício formam a base destas células cristalinas. Quanto mais fina é a lâmina de silício, menos material se gasta. Dessa maneira, também é proporcional à espessura o custo de sua produção, que vem sofrendo reduções ao longo do tempo. Em 2003 estas células eram feitas com uma espessura de 320 micrômetros e essa espessura chegou, em 2010, a valores de 150 micrômetros (8).

O cristal simples, ou módulo monocristalino, se utiliza de células que são cortadas de uma lâmina de silício que provém de cristal com formação uniforme e única. Devido à pureza garantida pelo processo de fabricação e exigida para criação destes módulos, são mais caros, porém estão entre os de maior eficiência por possuir um rendimento entre 15 e $20 \%$ para uma espessura de 300 micrômetros e estrutura molecular homogênea (14).

O módulo multicristalino ou policristalino é formado por células obtidas de "cortes" de cristais de silício com várias faces. São menos uniformes que as anteriores e apresentam aparência de vidro estilhaçado. É o tipo mais acessível para compra, por possuir menor custo em sua produção. Seus módulos são menos eficientes, embora venham sendo otimizados nos últimos anos, apresentando rendimento entre 15 e $18 \%$ também para uma espessura de 300 micrômetros e estrutura com cristais em diferentes orientações (14). 
Há também os módulos de película fina, que são obtidos a partir da deposição de camadas extremamente finas que apresentam espessuras de dezenas de micrômetros de materiais fotossensíveis sobre bases com baixo custo, como vidro, plástico e aço inoxidável (8). Possui um custo de fabricação final menor do que as duas tecnologias anteriormente abordadas. São constituídos, principalmente, de silício amorfo (Si-a), disseleneto de cobre índio (CIS, CIGS) e telureto de cádmio (CdTe). Esta película fina multicristalina sobre cristal (CSG - Crystalline Silicon on Glass) é muito utilizada por permitir a combinação de silício amorfo e microcristalino (Si-a/Si-m) que apresenta bons resultados (8).

O silício amorfo, uma forma não cristalina de silício, foi o primeiro material utilizado em células de película fina, aplicadas em calculadoras eletrônicas portáteis (19). Este material pode ser inserido em finas camadas sobre uma grande gama de superfícies. Possui custo inferior às células de silício cristalino, porém, em contrapartida, apresenta uma eficiência bem menor e, por isso, uma aparição bem menor quando se fala em termos de vendas (19). Seu rendimento varia entre 5 e $8 \%$, sendo $7 \%$ uma média encontrada na maioria de suas células (8). Apresentam espessura de cerca de 10 micrômetros. Sua maior vantagem é a do baixo custo, porém possui menor rendimento que a de mesmo material cristalino. Pode ser fabricada em série e permite uma densidade muito maior de dispositivos por conjunto. Por fim, ela pode ser inserida em qualquer substrato de metal condutor ou vidro.

As células fabricadas de filme fino obtidas através de Disseleneto de Cobre índio $\left(\mathrm{Cu}(\mathrm{IN}, \mathrm{Ga}) \mathrm{Se}_{2}\right)$ recebem o nome comercial de CIS (CIGS) e possuem participação ativa no mercado mundial de cerca de $0,2 \%$, apresentando um rendimento médio de $13 \%$ (19). Sua produção é escassa devido à alta demanda de Índio utilizada na fabricação de monitores e televisores de tela plana, LCD e plasma.

A tecnologia mais eficiente empregada em células solares nos dias de hoje é feita a partir de um semicondutor III-V (3-5) que é o Arseneto de gálio (GaAs). Este tipo de célula consegue alcançar rendimentos de até $28 \%$ (22), porém possui um custo de produção extremamente alto, o que torna seu valor de venda impraticável no cenário atual, sendo utilizada em painéis solares de satélites artificiais (9). As 
características a serem pontuadas dessa tecnologia são (8) a estrutura cristalina bem parecida com a do silício, apresenta ótimo desempenho quando é operada com concentradores (trabalhando em altas temperaturas), possui vantagens quando utilizadas para fins espaciais, eficiência em termos de rendimento superior a qualquer outra tecnologia, possui processo de fabricação complexo e produção extremamente custosa.

Ainda podemos citar as células obtidas a partir do composto semicondutor formado por cádmio e telúrio, o telureto de cádmio (CdTe). Os painéis solares feitos com estas células são produzidos em vidro. Possui menor custo para comercialização em relação as de silício. Como esperado, este material não possui a mesma eficiência se comparado a um silício cristalino, porém possui maior resistência à altas temperaturas. Em 2012, já possuía uma participação no mercado de $1,1 \%$ (9). Esta tecnologia utiliza-se de filmes finos de telureto de cádmio com espessura de 8 micrômetros, rendimento aproximado entre 6 e $9 \%$ e uma estrutura homogênea (14).

Existe ainda outro tipo de célula concentradora que enfoca a luz em uma pequena área através de um concentrador óptico, que se utiliza de uma lente de Fresnel (lentes extremamente finas que permitem passagem de muita luz) com alto índice de concentração (19). Nesta pequena área é colocado um material com composição de semicondutores III-V, e obtêm-se fantásticos resultados com rendimentos de até 30\%, podendo chegar a $40 \%$ em testes experimentais laboratoriais (2). Porém, este tipo de célula, além de possuir um custo altíssimo, não pode utilizar luz difusa e sua orientação em relação ao Sol deve ser extremamente precisa.

\subsection{JUNÇÕES PN}

Como o trabalho atual visa o estudo de células solares voltadas para o fornecimento de energia à circuitos confeccionados em lâminas SOI utilizando-se o próprio substrato da lâmina, todo o estudo será baseado em células solares fabricadas em silício monocristalino. Tais células tem seu funcionamento baseado em junções PN, em que o silício é dopado com diferentes materiais. 
Em um material intrínseco há um número pequeno de portadores, tanto de elétrons quanto de lacunas, devido ao teor mínimo de impurezas (13). A partir da descrição dos materiais extrínsecos, no material $\mathrm{N}$ o número de elétrons excede o de lacunas. Por esta razão, afirma-se que, no material tipo $\mathrm{N}$, o elétron é o portador majoritário e a lacuna é o portador minoritário. Este fenômeno é inverso no material do tipo $P$, em que são as lacunas que excedem os elétrons (24).

Malvino (34) descreve que estes dois materiais são os blocos básicos na construção de dispositivos semicondutores e a união deles resulta em uma junção PN, ou diodo. A partir desta união, os elétrons e as lacunas nesta região de junção se combinam, formando "dipolos" e dando origem a uma ausência de portadores livres, recebendo o nome de região de depleção. Na figura 10, é apresentado de forma simples o esquema de uma junção PN com a região de depleção no centro.

Figura 10 - llustração da junção PN e região de depleção.

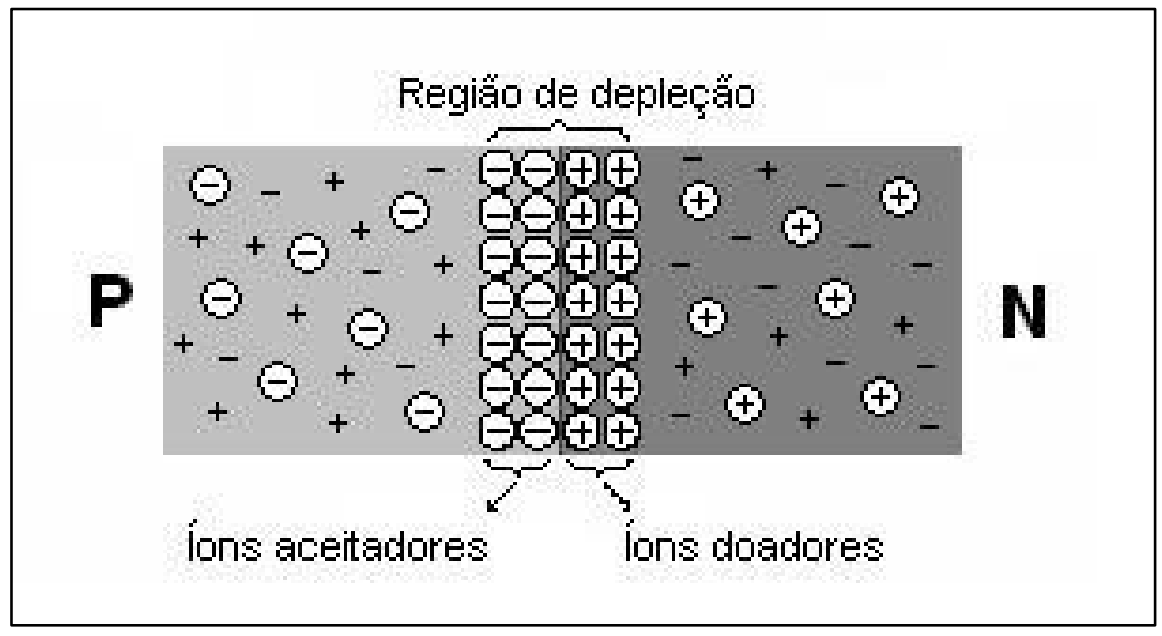

Fonte: Adaptado de (35).

A equação da largura da região de depleção (d) de um diodo de junção PN pode ser analisada a seguir a partir da resolução da equação de Poisson para um diodo (35):

$$
d=\sqrt{\frac{2 \varepsilon_{r} \varepsilon_{0}\left(V_{B i-} V_{D}\right)}{q}}\left(\frac{1}{N_{A}}+\frac{1}{N_{D}}\right)(11)
$$


onde $N_{A}$ é a concentração de dopantes aceitadores, como o boro, e $N_{D}$ a concentração de dopantes doadores, como o fósforo, $\varepsilon_{0}$ é a permissividade elétrica no vácuo $\left(8,85 \times 10^{-12} \mathrm{~F} / \mathrm{m}\right), \varepsilon_{\mathrm{r}}$ é a permissividade relativa do material $(11,7$ para o silício), q é a carga do elétron, dada por $1,6 \times 10^{-19} \mathrm{C}, \mathrm{V}_{\mathrm{Bi}}$ é o potencial de contato ou interno do diodo (built-in voltage), também denominado "barreira de potencial", e $V$ é a tensão aplicada entre os terminais.

Cada dipolo presente entre as regiões $\mathrm{P}$ e $\mathrm{N}$ possui um campo elétrico entre os dois íons. Quando elétrons livres adicionais no material $N$ penetram a região de depleção, este campo tenta empurrar eles para a parte $\mathrm{N}$ de volta. $\mathrm{A}$ intensidade do campo aumenta à medida que os elétrons cruzam a junção até estabelecer um equilíbrio e que dá origem à "barreira de potencial". Numa temperatura ambiente, $300 \mathrm{~K}$, esta barreira tem seu valor aproximado para $0,7 \mathrm{~V}$ nos diodos de silício (25). O potencial de contato de um diodo pode ser determinado da seguinte forma:

$$
V_{b i}=\left(\frac{k T}{q}\right) \ln \left(\frac{N_{A} N_{D}}{n i^{2}}\right)
$$

Este equacionamento do potencial de um diodo depende da concentração de dopantes e da temperatura em que o diodo está operando.

Também a partir da equação de Poisson, pode se descobrir a largura da região de depleção da de cada um dos lados de uma junção PN. Podemos encontrar e calcular o seu ponto máximo para o lado $\mathrm{P}$ de acordo com a seguinte equação:

$$
d \max =\sqrt{\frac{4 \cdot \varepsilon_{S i} \cdot \emptyset_{F p}}{q \cdot N_{A}}}(13)
$$

Com a utilização desta equação, pode-se verificar que a RDD se prolonga mais para o lado menos dopado da junção. Através destas equações é possível notar que a concentração de dopantes é inversamente proporcional ao tamanho da região de depleção, ou seja, quanto mais dopado é o material, menor região de depleção ele possui. A dopagem das junções PN em diodos convencionais geralmente é da ordem de $10^{16}$ a $10^{18}$ dopantes por centímetro cúbico. Para calcular a depleção máxima do lado tipo $\mathrm{N}$, basta substituir a concentração de impurezas 
aceitadoras $\left(N_{A}\right)$ pela concentração de impurezas doadoras $\left(N_{D}\right)$, além do potencial de Fermi de $\varnothing_{\mathrm{Fp}}$ para $\varnothing_{\mathrm{Fn}}$,

Quando o diodo não é influenciado por uma fonte de tensão e está em seu estado de equilíbrio, considera-se este dispositivo não polarizado. Ao se conectar uma fonte de tensão contínua entre seus terminais, de modo que seu terminal negativo esteja conectado na região tipo $\mathrm{N}$ e o terminal positivo conectado na região tipo $\mathrm{P}$, afirma-se que o diodo está polarizado diretamente (para tensões superiores a $0,7 \mathrm{~V})$. Quando a conexão ocorre de forma contrária, o fluxo de corrente é desprezível e o dispositivo se equivale a um circuito aberto. Neste caso, considerase que o diodo está reversamente polarizado.

Sedra e Smith (36) relacionam em seus escritos que o terminal positivo do diodo é chamado de anodo e o negativo de catodo, nomenclaturas provindas dos diodos à válvula. Conforme figura 11 , podemos observar da esquerda para a direita a simbologia do diodo, a curva característica da tensão pela corrente considerando um diodo ideal, e sua curva real obtida através de medidas experimentais.

Figura 11 - Diodo semicondutor: símbolo, curva I x V do diodo ideal e do diodo real.

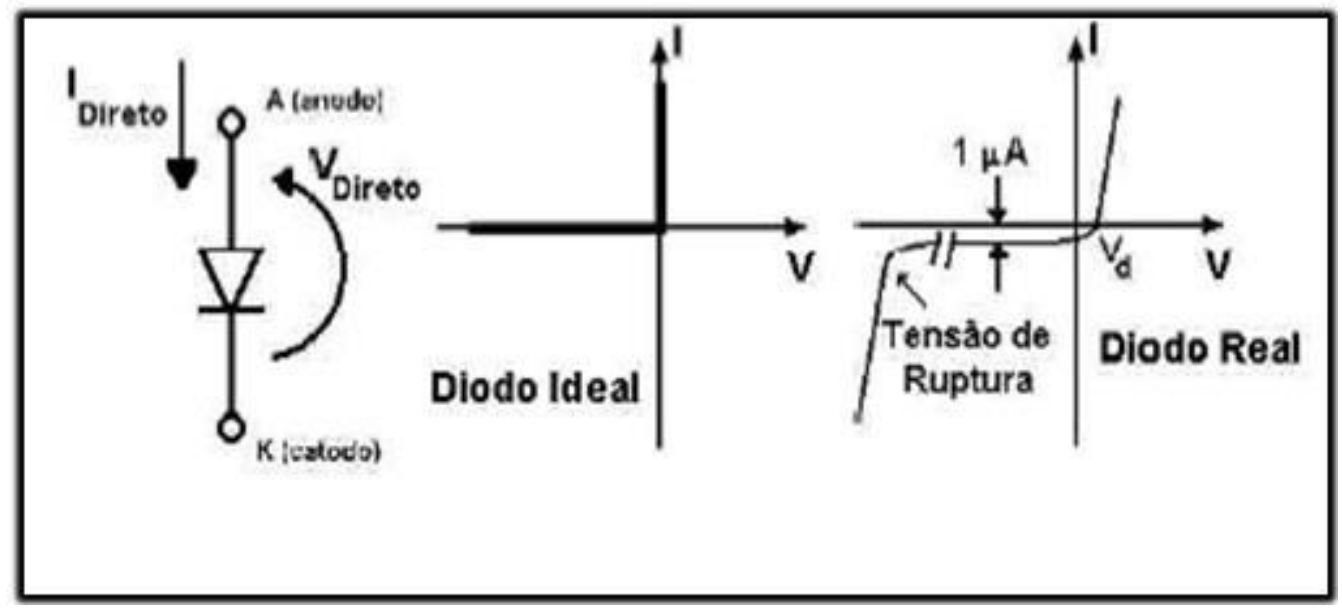

Fonte: Adaptado de (34), 2006, p.66.

Dentre as várias aplicações dos diodos, podemos incluir retificador de ondas senoidais, regulador de tensão e células solares. Trabalhando juntamente com resistores são utilizados para implementar funções lógicas digitais. Abaixo são apresentados, sucintamente, os principais tipos especiais de diodos: 
- Diodo de barreira Schottky: formado a partir de um metal e um semicondutor moderadamente dopado. Comporta-se como um diodo convencional. Conduz corrente do metal para o semicondutor e também atua como circuito aberto caso polarizado reversamente à condução. Podem ser feitos de arseneto de gálio (GaAs), possuindo menor queda de tensão que os diodos comuns e são rapidamente comutados do estado ligado para desligado. São utilizados de maneira ampla na fabricação de circuitos integrados (24);

- Varactores: são diodos de junção pn reversamente polarizados, fabricados especialmente para funcionarem como capacitores de tensão variável (24);

- LEDs (Diodos emissores de luz): convertem corrente direta em luz. Ao ser polarizado diretamente, ocorre a recombinação dos portadores majoritários e minoritários, que leva à emissão de luz. Podem ser obtidos com a fabricação da junção PN utilizando semicondutores que possuem a faixa proibida no modo de transição direta, com largura de banda proibida apropriado. O arseneto de gálio pertence a este grupo e é usado na obtenção de LEDs (34). No caso do silício, em que sua banda proibida emite fótons com comprimento de onda superior aos de luz visível, não é possível utilizá-lo para tal fim (1).

$\mathrm{Na}$ aplicação como células solares, usualmente são utilizados diodos convencionais. A incidência de fótons na junção $P N$ fornece energia para elétrons no interior da região de depleção, rompendo ligações covalentes. Com a ação de um campo elétrico, os elétrons livres gerados são incorporados à corrente do diodo, de modo que este componente pode ser utilizado como gerador de energia. Quanto maior a região de depleção, maior será a corrente gerada pela incidência de fótons. Logo, ao serem aplicados como células solares diodos são polarizados reversamente, onde a largura da região de depleção é maior. Uma forma de aumentar ainda mais a largura da região de depleção, de modo a aumentar a eficiência da célula solar, consiste na utilização de diodos PIN, os quais serão vistos a seguir. 
Introduzido tais conceitos, pode-se mencionar que a célula solar fabricada a partir de uma junção PN pode ter estrutura lateral ou vertical. Na estrutura lateral, os fótons incidem de modo perpendicular à junção $P N$, enquanto que na vertical os raios solares incidem paralelamente à junção, como mostrado na figura 16. A estrutura lateral é mais adequada em relação a vertical para célula solar devido ao seu ganho pelo efeito avalanche, que proporciona maior eficiência ao dispositivo. A geração de portadores de carga responsável pela condução elétrica que ocorre no dispositivo é explicitada sobre o diodo apresentado na figura 12, após a incidência dos fótons na superfície de uma placa de silício onde se encontram os diodos.

Figura 12 - Gravura simplificada do efeito fotovoltaico em uma placa solar vertical feita a partir de uma junção PN.

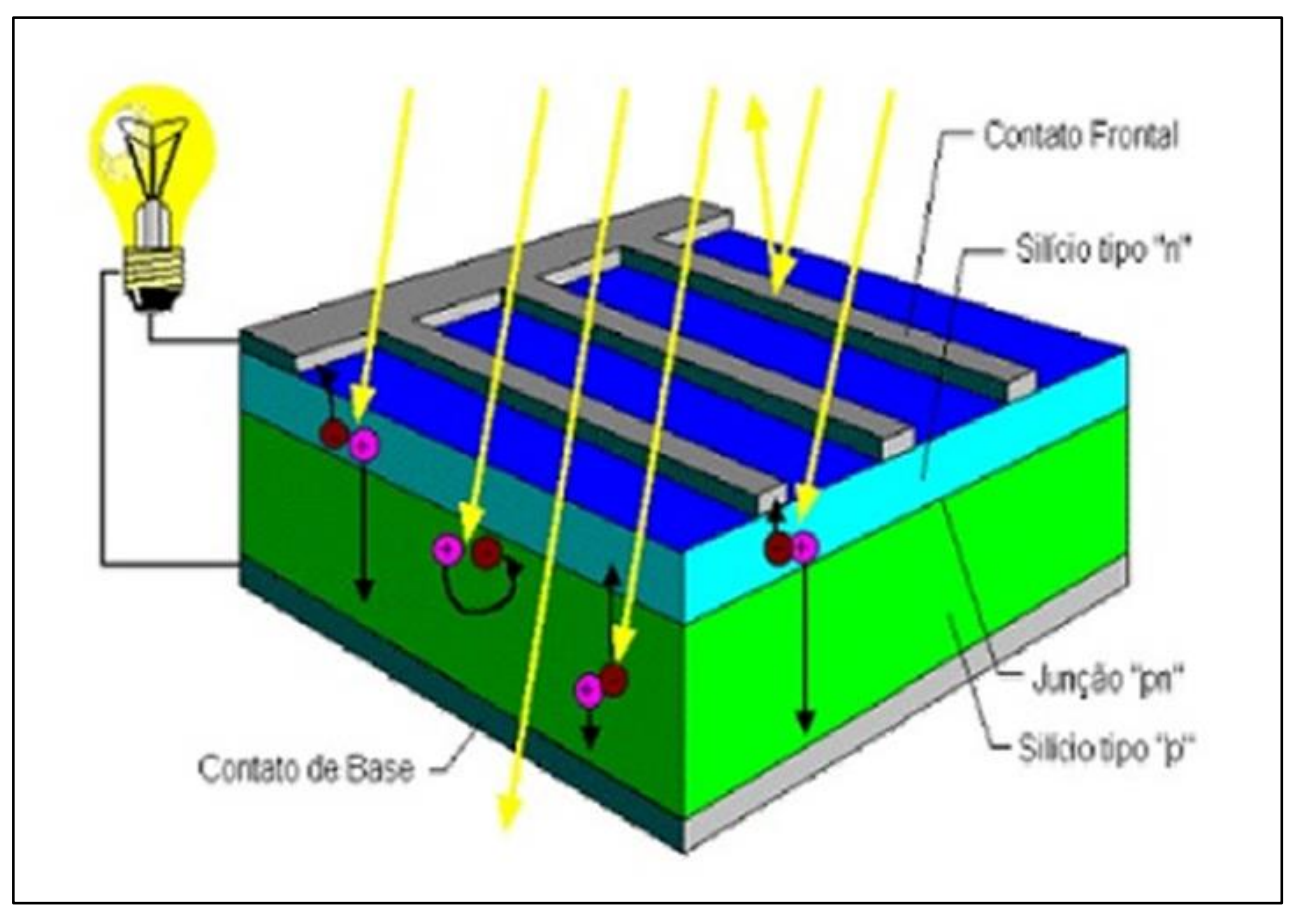

Fonte: Adaptado de (8), 2012. 


\subsubsection{Diodos PIN}

Diodos PIN são dispositivos de estado sólido desenvolvidos, originalmente, a partir de um diodo PN comum, com a inserção de uma região intrínseca entre a $\mathrm{P}$ e a $\mathrm{N}$, cujo comprimento é especificado através de $\mathrm{L}_{\mathrm{i}}$. Pode ser utilizado em polarização reversa como fotodetectores para a detecção de luz com pequenos comprimentos de onda próximos ao ultravioleta (12). Porém, sua principal utilização pela indústria é como retificador, transformando corrente alternada em corrente contínua. Além disso, eles podem trabalhar em circuitos com altas frequências, operando como resistência, por gerarem uma queda de tensão entre seus dois terminais. Quando polarizados diretamente, podem também ser utilizados em baixa frequência na transmissão de ondas de rádio, mas são mais adequados para atenuação de sinal e limitador de fluxo de corrente (4).

Como já abordado anteriormente, são gerados pares elétron-lacuna devido à incidência de fótons originários do espectro solar que atingem a região de depleção do diodo e, com a ação de um campo elétrico, eles se dispersam e separam. Observa-se nesta situação que, quanto maior o comprimento da região de depleção, maior é quantidade de fótons que podem ser absorvidos, tornando-a uma característica extremamente importante. Mesmo para dopagens da ordem de $10^{16}$ $\mathrm{cm}^{-3}$, a profundidade da região de depleção é limitada (da ordem de 0,3 $\mu \mathrm{m}$ ). Logo, a solução mais adequada para se aumentar a região de depleção de um diodo, visando uma maior absorção de fótons, é a inserção de uma região com dopagem intrínseca entre as regiões $\mathrm{P}$ e N. A presença desta região I, chamada de intrínseca garante um tamanho maior para região de depleção sem alteração das dopagens das regiões $\mathrm{P}$ e $\mathrm{N}$. Porém, se o seu comprimento for muito extenso, os portadores de carga formados junto à depleção podem se recombinar ainda no interior da região intrínseca e se "perder" antes de chegar às regiões de catodo e anodo (N e P respectivamente) (37). 
Na Figura 13, temos uma representação do diodo PIN, uma simbologia com indicação das regiões $\mathrm{P}, \mathrm{I}, \mathrm{N}$ e como ele recebe energia ótica.

Figura 13 - Esquema do funcionamento do diodo PIN absorvendo energia ótica.

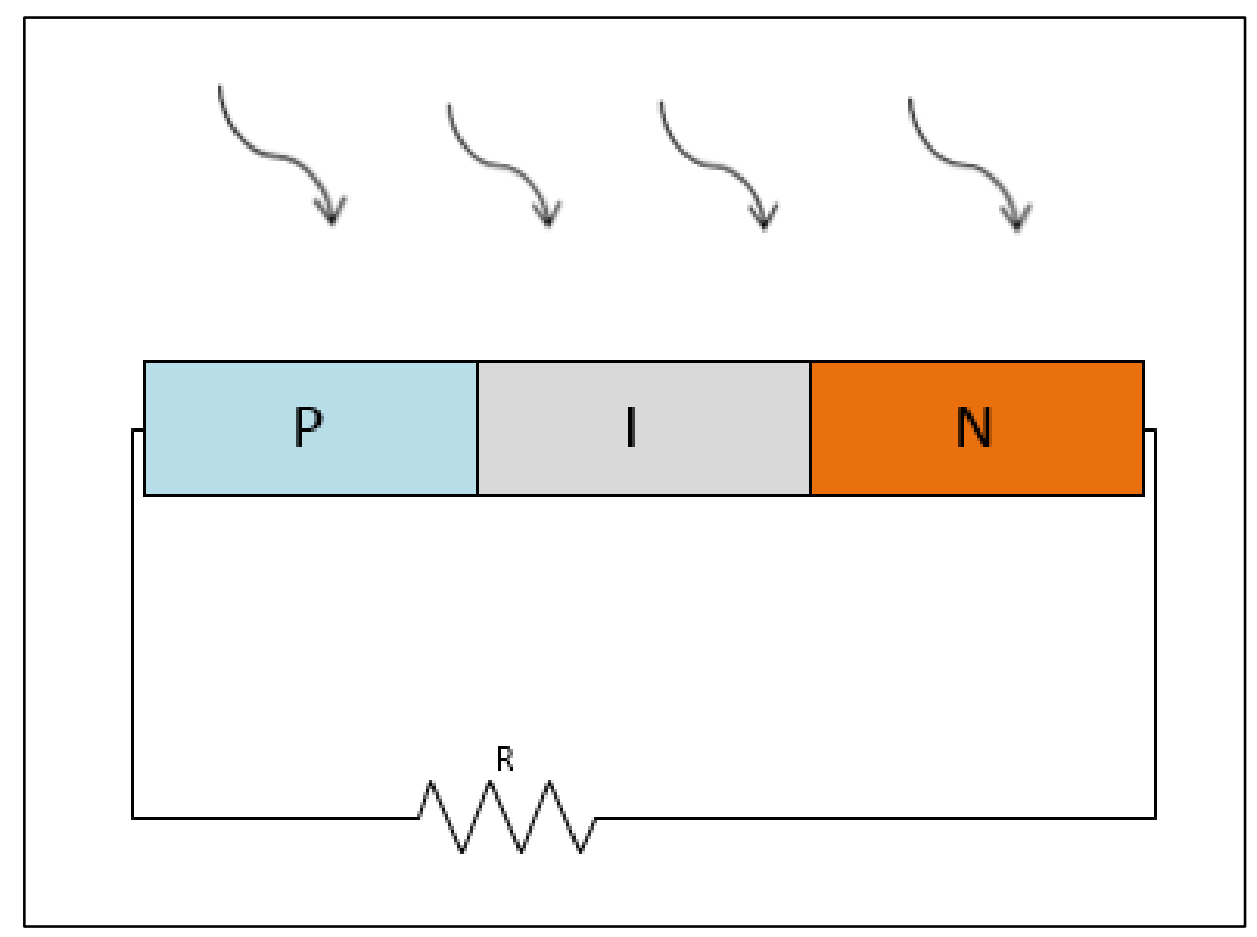

Fonte: Adaptado de (12).

$\mathrm{Na}$ esquematização apresentada na figura 13, o diodo absorve a energia proveniente da radiação solar e gera a corrente elétrica de forma cíclica na região de depleção, alimentando a resistência externa. Sendo assim, como o PIN entrega a potência gerada para um circuito externo, esta operação é realizada no quarto quadrante, caso tenha-se como referência a curva da corrente em função da tensão em um plano cartesiano. 
Figura 14 - Representação gráfica da curva da corrente quando se opera a célula solar no diodo PIN no terceiro e quarto quadrante.

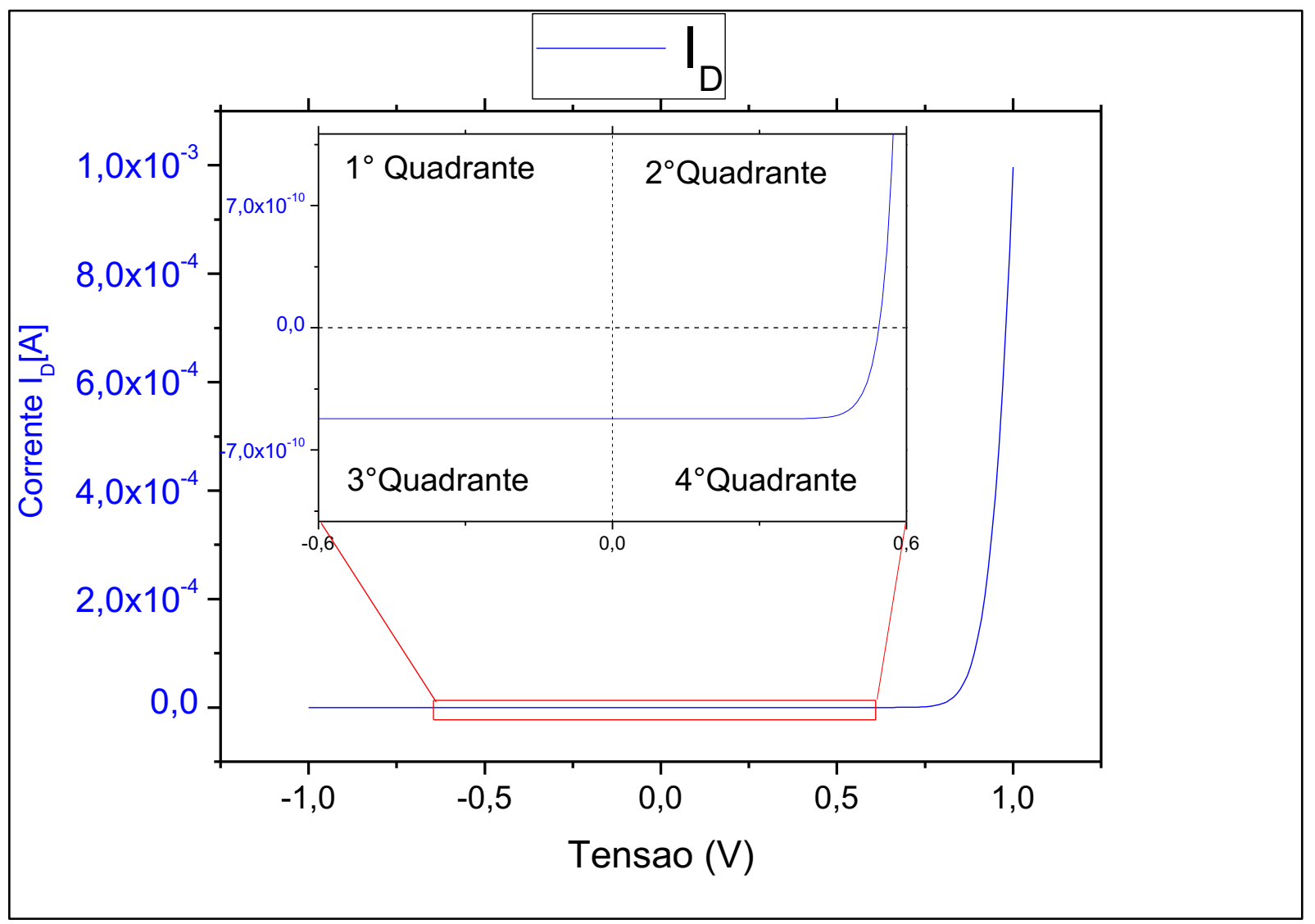

Fonte: Autoria própria, 2017.

Na figura 14 é apresentada a curva de corrente em função de tensão de um diodo PIN operando como célula solar de comprimento intrínseco de $2 \mu \mathrm{m}$ simulado. Agora, quando o diodo PIN está operando como fotodetector o ponto de trabalho de sua corrente é diferente ( $3^{\circ}$ quadrante), fazendo com que este não gere corrente ou potência para um circuito externo como na célula solar.

\subsection{TECNOLOGIA SOI (Silicon-on-Insulator)}

Com a grande demanda de se reduzir cada vez mais o tamanho dos circuitos e dispositivos eletrônicos, visando aumentar a sua densidade de integração, além de baixar os custos de fabricação desde o fornecimento da matéria prima até o processo final, a tecnologia MOS convencional se deparou com grandes problemas em termos de redução de dimensões (38). 
Os maiores empecilhos encontrados com a tecnologia supracitada ocorrem quando se tem um comprimento de canal muito curto nos transistores MOS, o que leva a uma redução no controle de cargas na região de canal degradando suas características elétricas.

Devido às necessidades do mercado e os problemas encontrados, uma nova tecnologia de fabricação de dispositivos foi desenvolvida. Abordada por sua nomenclatura em inglês SOI (Silicon-on-Insulator), ou silício sobre isolante, esta levou a miniaturização de circuitos a um novo patamar (5). A ideia de se colocar uma camada de óxido de silício entre a região ativa da lâmina e seu substrato trouxe diversos avanços em termos de desempenho e redução de efeitos de canal curto, entre outros problemas (39). A Figura 15 demonstra um transistor fabricado em substrato de tecnologia SOI.

Figura 15 - Ilustração legendada de um transistor MOS implementado com a tecnologia SOI.

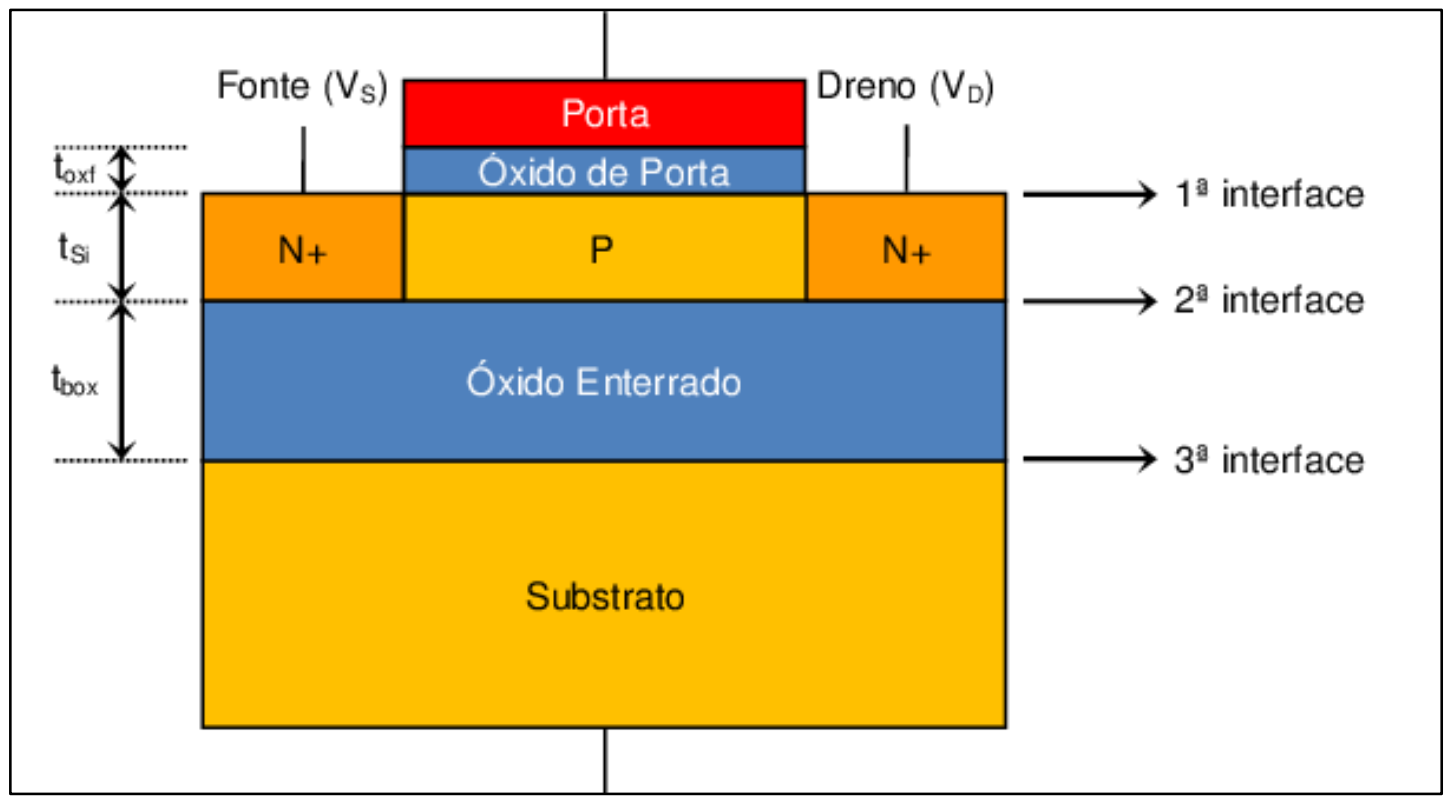

Fonte: (40), 2014.

Acerca da figura 15, temos um transistor fabricado em uma lâmina de tecnologia SOI. Dentre suas características indicadas, tem-se que $V_{S}$ é a tensão de fonte, $V_{D}$ é a tensão de dreno, $t_{o x f}$ é a espessura do óxido de porta, $t_{S i}$ é a espessura da camada de silício e $t_{\text {box }}$ é a espessura do óxido enterrado. Como se pode notar na figura, todo o transistor SOI é fabricado acima da camada de óxido enterrado, de 
modo que a presença do substrato da lâmina somente é necessária para sua sustentação mecânica.

Dentre as principais características e vantagens da tecnologia SOI que devem ser citadas, pode-se mencionar menor capacitância nas regiões onde se encontram as junções PN, além de maior densidade de integração dos seus circuitos em menor espaço pelo fato de não possuir as mesmas cavidades $\mathrm{P}$ e $\mathrm{N}$ necessárias para obtenção de uma lâmina MOS convencional (41), como observado e comparado na Figura 16, tendo inversores CMOS como objeto.

Figura 16 - Comparação das tecnologias SOI e CMOS em relação à integração de circuitos.

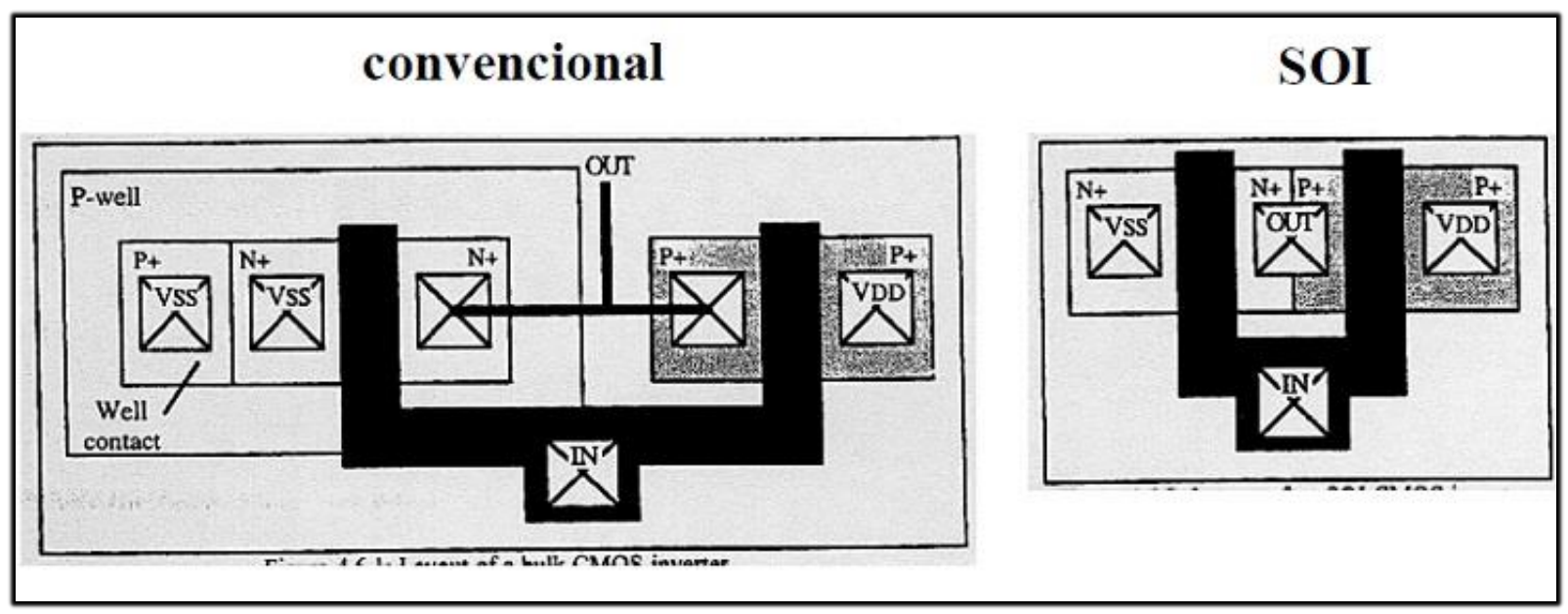

Fonte: Adaptado de Colinge, 2016.

A estrutura SOI permite a eliminação do efeito de tiristores parasitários (Latch up) que são inerentes à tecnologia MOS convencional e possuem as seguintes configurações PNPN e NPNP, dependendo exclusivamente de onde este se situa dentro do circuito (42). Em suas características ainda pode se observar uma melhor inclinação de sublimiar, que é causada, principalmente, pelo melhor acoplamento capacitivo e, segundo (38) pode gerar uma corrente de dreno cerca de $30 \%$ maior do que a observada em dispositivos convencionais. Finalmente, a presença da camada de óxido enterrado é responsável por reduzir os danos decorrentes da exposição de dispositivos SOI a partículas radioativas, o que resulta em melhor resistência a radiação (43). 
A tecnologia SOI é desenvolvida definitivamente para circuitos de baixa potência e baixa tensão, como demonstram os diversos circuitos comerciais desenvolvidos por diferentes empresas da área de microeletrônica (44). A IBM utilizou a tecnologia na construção de memórias SRAM de $4 \mathrm{Mb}$ e estas apresentaram uma potência dissipada de 1,7 a 3 vezes menor que na convencional (45). Além de memórias, em seguida a tecnologia SOI foi aplicada na produção de transistores, processadores e microprocessadores e toda uma gama de aplicações com baixa potência, inclusive células e painéis solares (27).

Citadas as características vantajosas desta tecnologia, é importante ressaltar as suas desvantagens para melhor conhecimento. Os circuitos fabricados em SOI são mais suscetíveis ao efeito de auto-aquecimento devido à sua maior resistência térmica, o que dificulta a dissipação de calor (5). Já, devido à separação entre substrato e circuito, temos a aparição de efeitos de corpo flutuante em sua estrutura (2).

\subsubsection{Diodos PIN fabricados em tecnologia SOI}

Os diodos PIN, como já mencionado anteriormente, podem ser utilizados como fotodetectores e células solares. Ao fabricá-los em lâminas SOI, entretanto, a presença da camada de óxido enterrado a algumas dezenas ou poucas centenas de nanômetros abaixo da camada de silício limita a absorção de comprimentos de onda superiores a 400-450 nm. Entretanto, como mencionado anteriormente, dispositivos fabricados através da tecnologia SOI apresentam vantagens em relação a dispositivos convencionais (41). O óxido enterrado, comumente dióxido de silício, separa o dispositivo do substrato, garantindo um funcionamento melhor em altas e baixas temperaturas.

Assim, apenas diodos PIN visando a detecção de comprimentos de onda ultravioleta $(\lambda<400 \mathrm{~nm})$ ou azul $(\lambda \approx 400 \mathrm{~nm})$, podem ser fabricados na região ativa de lâminas SOI. Segue na figura 17 um exemplo, em duas dimensões, de um diodo $\mathrm{PIN}$, fabricado na tecnologia SOI que possui um comprimento intrínseco Li de 8 micrômetros. O diodo em questão é fabricado na região ativa da lâmina, cuja camada de silício apresenta espessura de apenas $80 \mathrm{~nm}$. Considerando-se que a 
espessura da camada de silício necessária para a absorção de comprimentos de onda de todo o espectro solar é da ordem de alguns micrômetros, pode-se constatar que o dispositivo esquematizado na figura terá um baixo desempenho ao ser aplicado como célula-solar (46) (47).

Figura 17 - Diodo PIN fabricado em tecnologia SOI, vista frontal.

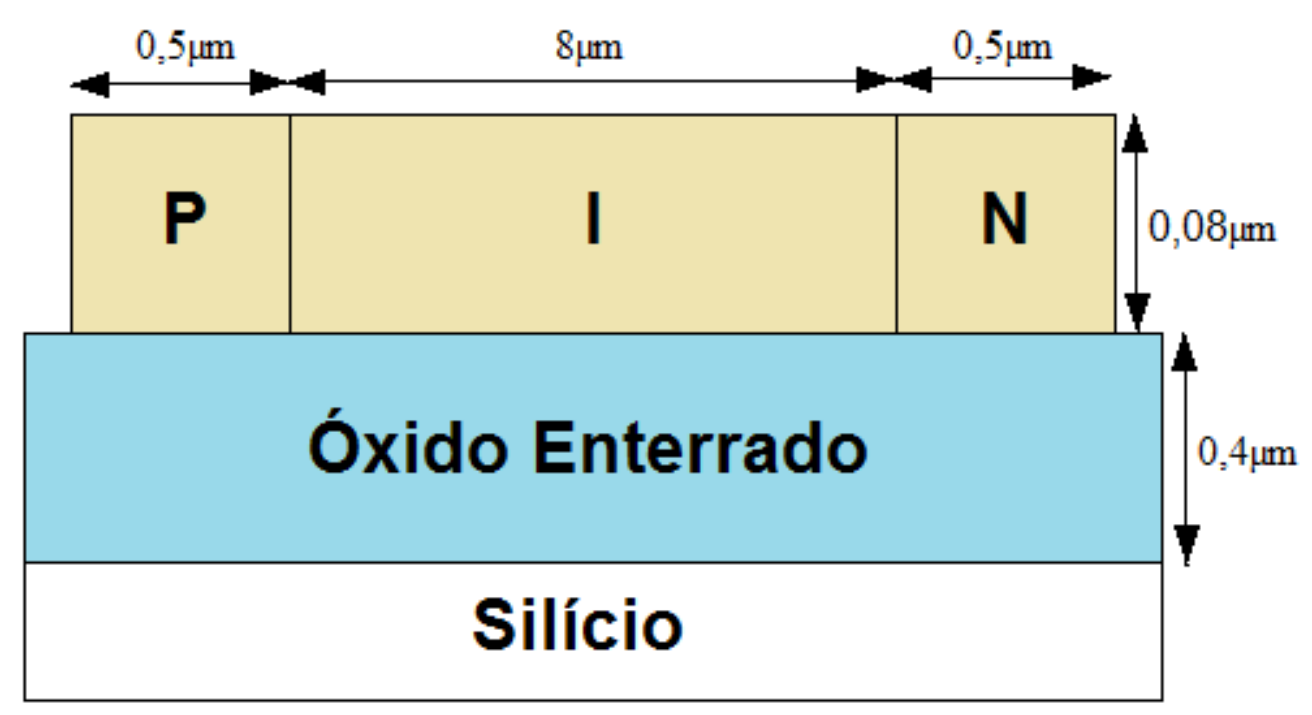

Fonte: Adaptado de (12).

Com vistas à aplicação como células solares, os diodos PIN podem, então, ser fabricados no substrato de lâminas da tecnologia SOI (Silicon-on-Insulator), abaixo da camada de óxido enterrado, a qual apresenta espessura de algumas centenas de micrômetros, permitindo a absorção de luz de grande parte do espectro solar. Ao se fabricar diodos PIN no substrato da lâmina, a energia gerada ao se utilizá-los como célula solar pode ser aplicada na alimentação dos circuitos fabricados na região ativa.

Comumente, o substrato de uma lâmina SOI é fracamente dopado com uma impureza aceitadora com concentração média de $N_{A}=1 \times 10^{15} \mathrm{~cm}^{-3}$. Para a implantação das regiões de catodo e anodo do diodo no substrato é necessário corroer o óxido de silício enterrado. A exemplo de uma camada com espessura de 400 nm, 370 nm são corroídos através de reação iônica e o restante a partir de ácido clorídrico (48). Então, óxido de silício é acrescido bem em cima da fina camada de silício e também do substrato nas regiões dos contatos com espessura de cerca de 
$30 \mathrm{~nm}$ e, através deste óxido, são implantadas as regiões de anodo e catodo. As dopagens deste exemplo são de $4,5 \times 10^{15} \mathrm{~cm}^{-2}$ de arsênio para a região $\mathrm{N}$ e $5 \times 10^{15}$ $\mathrm{cm}^{-2}$ de boro para a região $\mathrm{P}$ (12). Ao fim deste processo, essa junção deverá estar a uma profundidade de $200 \mathrm{~nm}$ como é indicado na figura 18. Como pode ser observado na figura, há a formação de uma resistência na região $P$ na interface com o substrato. Em seguida, indicado abaixo do óxido enterrado, está o diodo PIN e, à sua direita, temos a região $\mathrm{N}$ que forma uma junção PN vertical a partir da dopagem do substrato que o torna uma região $P$.

Figura 18 - Esquema de um diodo PIN fabricado em substrato SOI.

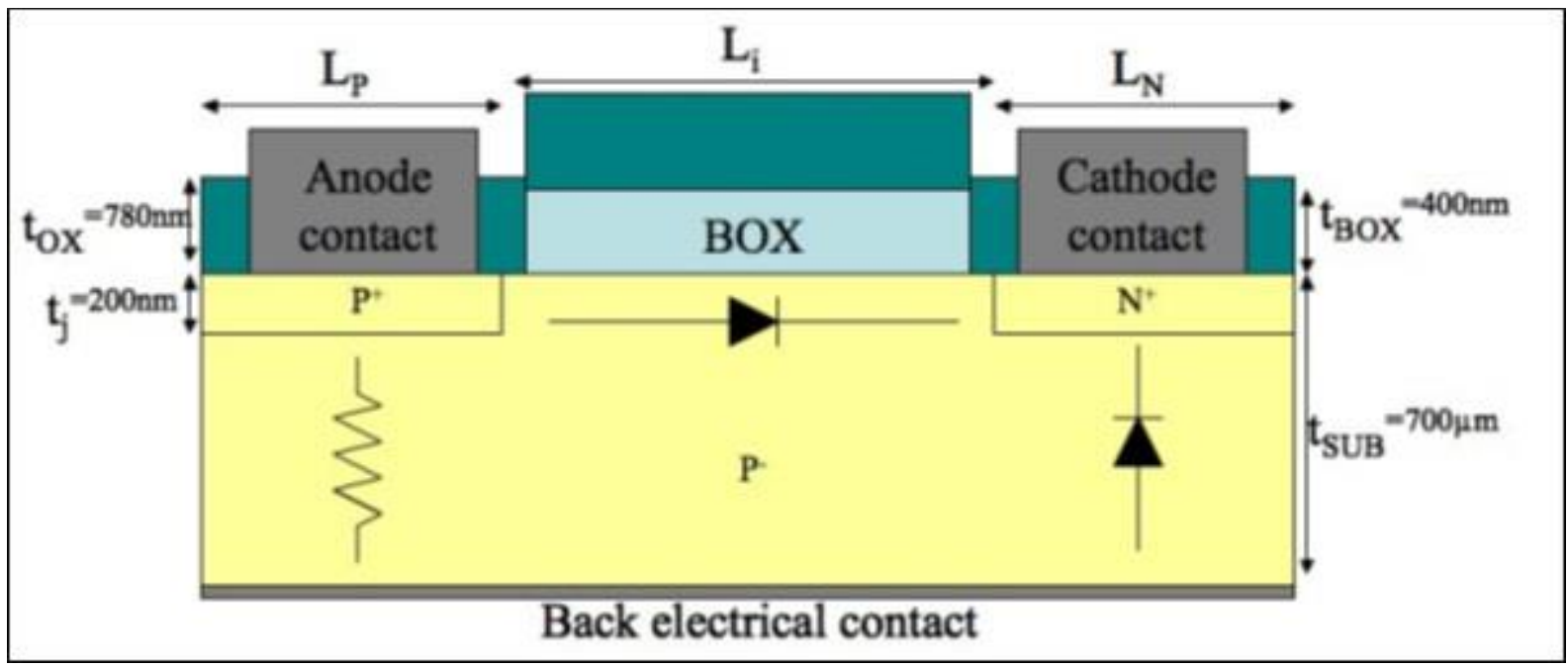

Fonte: Adaptado de (12), 2011, p.123.

Temos, na figura 18, a indicação dos comprimentos de todas as regiões: $P$, intrínseca e $N, L_{P}$, Li e $L_{N}$ respectivamente, os contatos de anodo e cátodo nos quadrados cinza, a espessura do óxido de campo (tox $=780 \mathrm{~nm}$ ) e a camada de óxido enterrado, representada por BOX com espessura $t_{\mathrm{BOX}}=400 \mathrm{~nm}$. Acima do óxido enterrado está uma camada de óxido de passivação. Este é um dispositivo sem porta. Ambas as regiões da junção, $P$ e $N$, estão a uma profundidade representada pela espessura de cada região $t_{j}=200 \mathrm{~nm}$ e o substrato apresenta espessura $_{\text {suB }}=700 \mu \mathrm{m}$. 
Tomemos agora a abordagem para a célula produzida com porta. De acordo com Bulteel (12), pode-se otimizar a geração de energia em uma célula solar ao se colocar uma porta sobre a camada de óxido enterrado. Esta porta pode ser implementada através da formação de um diodo PIN na região ativa da lâmina sobre o diodo PIN confeccionado no substrato, ou então, por um metal. No primeiro caso, ao se polarizar reversamente o diodo PIN na região ativa, haverá a formação de uma região de depleção na região intrínseca, a qual induzirá um aumento da carga de depleção do diodo PIN formado no substrato, melhorando a eficiência do dispositivo. No segundo caso, o metal formará uma estrutura MOS em conjunto com a camada de óxido enterrado e o silício, e apresentará funcionamento similar ao de um capacitor MOS, em que a polarização do metal induzirá um aumento na carga de depleção do diodo PIN, aumentando sua eficiência. Na figura 19 segue uma ilustração do esquema de um diodo PIN com porta, formada também por um diodo PIN, de um dispositivo fabricado na Bélgica.

Figura 19 - Célula Solar com porta, fabricada na tecnologia SOI.

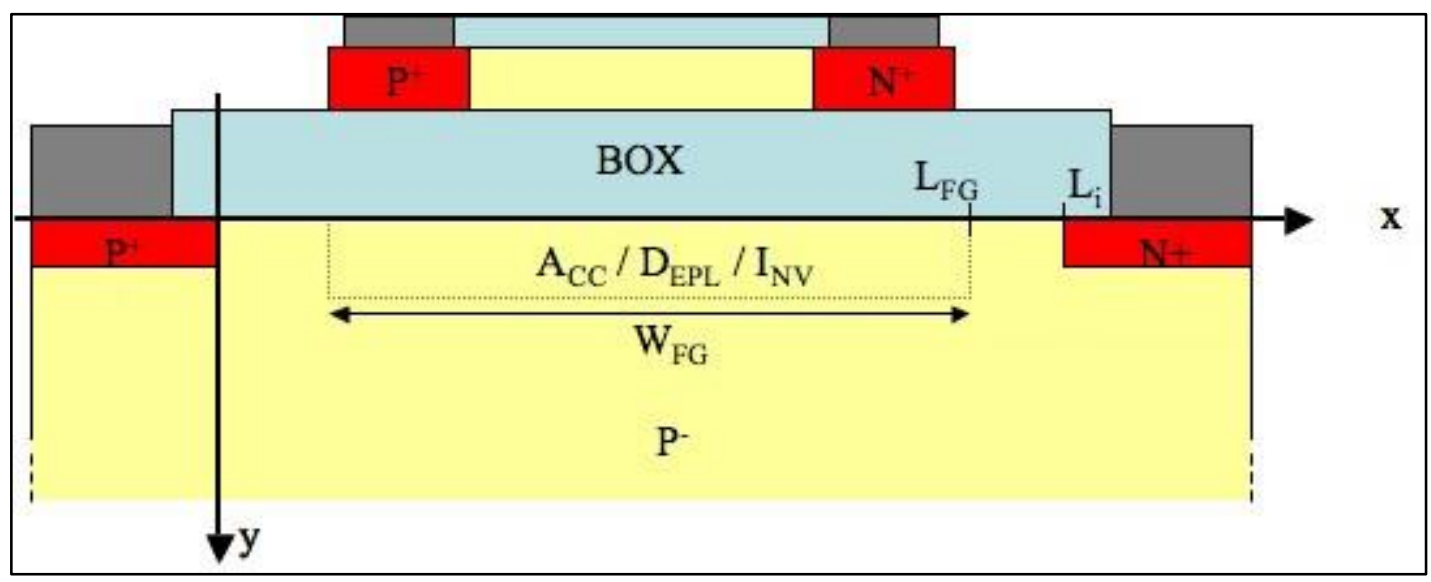

Fonte: Adaptado de (12), 2011, p.134.

Logo no início da análise da figura podemos identificar o diodo PIN acima de uma camada de óxido enterrado entre as regiões de anodo e catodo. A célula se situa abaixo da região ativa da lâmina de SOI. Diferentemente da célula sem porta, esta apresenta três regiões de funcionamento dependendo da tensão aplicada, acumulação $\left(A_{C C}\right)$ com tensão negativa, depleção $\left(D_{E P L}\right)$ com valores de tensão próximos a zero e inversão $\left(I_{N V}\right)$ com tensão positiva. Com exceção do regime de acumulação, os outros dois apresentam comportamento parecido com o da célula sem porta. 
Devido à sua estrutura, a célula solar com porta tem um comportamento diferente com a geração de foto corrente, o que pode melhorar a geração de corrente do dispositivo, proporcionando maior eficiência quântica e, consequentemente, maior rendimento. Diferentemente da que foi apresentada na figura acima, a porta utilizada nos estudos é feita de metal semicondutor apenas para inserção de tensão e controle do campo elétrico na região intrínseca do diodo.

Em um diodo PIN, a largura da região de depleção (RDD) é de extrema importância na recepção da radiação solar e ela pode variar até sua largura máxima dependendo da polarização que ocorre entre as regiões $P$ e $N$. Com polarização direta, se possui uma corrente de difusão maior que de deriva, e com isso a região de depleção diminui. Com polarização reversa, a corrente de deriva passa a ser maior que a de difusão aumentando a região de depleção. Neste regime de operação se observa uma melhor geração de portadores, sendo assim quando o diodo está operando como célula solar ou fotodiodo. Quando se ilumina a RDD de um PIN polarizado reversamente, pares elétron-lacuna são gerados. Devido ao campo elétrico horizontal, os pares são separados e conseguem chegar ao anodo e ao catodo antes que ocorra uma recombinação dos portadores. (48) 


\section{SIMULAÇÃO}

\subsection{SIMULADOR SYNOPSYS SENTAURUS}

O Sentaurus Device Simulator (6) é uma ferramenta de simulação para dispositivos eletrônicos que opera a partir do sistema operacional Linux e é utilizada em todas as etapas desta pesquisa. Este software foi executado a partir do Sentaurus Workbench (SWB) (6), que é uma ferramenta de trabalho responsável por armazenar e gerenciar todas as informações do projeto que será simulado, a estrutura do dispositivo, gerada pelo Sentaurus Structure Editor (SDE), além de controlar as simulações e as possíveis variáveis inseridas no sistema. A interface é intuitiva, porém contém muita informação e ainda possui atalhos para buscar modelos de projetos, e qualquer outra informação alocada em sua biblioteca, inclusive dados sobre espectros solares.

Ele é capaz de fazer simulações bidimensionais e em três dimensões. Neste trabalho, serão utilizadas apenas simulações em duas dimensões dos diodos PIN que já fornecem os dados para as análises de forma adequada. O Sentaurus Device (SDEVICE) é responsável pela simulação das características elétricas do dispositivo estudado e necessita de um arquivo de entrada desenvolvido no SDE contendo a estrutura a ser simulada e sua grade. Um exemplo do arquivo de simulação da estrutura de um diodo PIN com $\mathrm{Li}=20 \mu \mathrm{m}$ é apresentado no Apêndice A deste trabalho.

O SDEVICE tem seu funcionamento baseado em equações e modelos físicos e é capaz de prever características elétricas de dispositivos desde potenciais, campos elétricos, quantidade de portadores de carga, bem como correntes e tensões. Todos estes parâmetros dependentes das condições de polarização do circuito e do ambiente. No caso dos dispositivos simulados, as condições do ambiente dizem respeito à temperatura e ao comprimento das ondas de luz que incidem na superfície do dispositivo. 
Os arquivos de simulação da estrutura e de suas características elétricas possuem uma linguagem diferente $\mathrm{e}$, por isso, têm extensão diferente para reconhecimento no simulador. Por serem alocados na mesma pasta, eles devem ser editados pela própria interface do Sentaurus ou por um editor de texto do próprio Linux. Os comandos não precisam seguir uma sequência lógica de execução tanto para a estrutura quanto para o circuito, uma vez tendo sentenças, comandos, rotinas e sub-rotinas bem definidas e separadas, é possível efetuar a simulação desejada.

É postado ao fim do desenvolvimento, no Apêndice $B$, o arquivo contendo a rotina utilizada para a simulação da característica $I_{D} \times V_{D}$ de um diodo PIN com substrato SOI operando como célula solar incidido por um espectro solar, com comprimento $\mathrm{Li}=25 \mu \mathrm{m}$, com uma tensão aplicada ao anodo do dispositivo que varia de -1 a $1 \mathrm{~V}$ com intervalos de $10 \mathrm{mV}$. Esta curva pode ser visualizada através da ferramenta Sentaurus Visual (SVISUAL), que pode ser acessada pela interface do SWB ou mesmo pelo Terminal de operações do Linux.

\subsubsection{Simulação da Estrutura}

Tendo em vista que as experiências se basearam em simulações da estrutura bidimensional considerando diodos PIN tanto fabricados na região ativa como no substrato, é importante ressaltar que ambas as estruturas podem ser utilizadas como células solares. Porém, quando se utiliza uma camada de silício muito fina é mais adequado que a finalidade desse diodo seja a de fotodetector para pequenos comprimentos de onda, enquanto uma camada mais espessa é mais adequada quando se trata de absorção e conversão de energia solar, o que resulta na obtenção de maior potência e melhores resultados finais em termos de rendimento e fator de forma.

\subsubsection{Simulação Numérica}

A simulação numérica nada mais é do que a aplicação dos cálculos matemáticos e modelos físicos que definem os resultados referentes à resposta elétrica do dispositivo, ou seja, aqueles que serão posteriormente utilizados para o 
cálculo do rendimento, por exemplo. Num primeiro momento, foram feitas as simulações de diodos PIN com fina camada de silício, com a finalidade de extrair os primeiros parâmetros da pesquisa propriamente dita, tais como correntes e tensões, visando entender o funcionamento do dispositivo e validar as curvas obtidas com resultados experimentais advindos da literatura. Na sequência, utilizou-se de células solares sem porta, tendo como foco inicial o fluxo de corrente que ocorre entre as regiões $\mathrm{P}$ e $\mathrm{N}$, que é condicionado pela incidência de fótons na região de depleção gerada onde se situa a região intrínseca. Na sequência, foram efetuadas simulações de dispositivos com porta e aplicação de fonte de tensão externa e, por fim, foram feitas simulações com diferentes temperaturas de trabalho para conhecer melhor o comportamento do diodo PIN SOI operando como célula solar.

\subsection{MODELOS UTILIZADOS NO SENTAURUS}

Conforme explicitado anteriormente, o arquivo de entrada da simulação recebe o valor de muitas variáveis, entre elas potenciais aplicados, dimensões de dispositivo, dopagens, comprimento de onda da luz incidente e uma tabela contendo informações da densidade de potência em função do comprimento de onda necessária para simular um espectro solar completo. Os escritos aqui encontrados são responsáveis por descrever quais e como são os modelos físicos utilizados neste trabalho. Além disso, desde o início da pesquisa, foram feitos vários estudos sobre modelos de simulação de dispositivos SOI em relação à mobilidade (49).

- BandGapNarrowing: importante em regiões altamente dopadas, este modelo diz respeito ao estreitamento da faixa proibida (50).

- $\operatorname{SRH}($ DopingDep TempDependence): modelo de recombinação onde o tempo de vida dos portadores dependente da concentração. Recomendado para estruturas de silício (51).

- HighFieldSaturation: modelo de degradação da mobilidade dependente do efeito de campo lateral, utilizado para estruturas de silício e arseneto de gálio. 
Necessário para a modelagem de qualquer efeito relacionado à velocidade de saturação dos portadores (52).

- PHUMOB (Philips Unified Mobility Model): modelo que une a descrição de mobilidade tanto dos portadores majoritários quanto dos minoritários. Além de descrever a dependência com a temperatura, ele contabiliza a dispersão de elétrons-lacuna e faz um agrupamento automático dos dados de impurezas e das impurezas ionizadas por portadores (53).

- Enormal: Modelo que indica a degradação de mobilidade dos dispositivos que ocorre devido ao campo elétrico transversal que atua de forma a empurrar os portadores da carga para a região de interface entre semicondutor e isolante. Os portadores normalmente se dispersam devido a rugosidades da superfície (54).

- Optical Generation: É o modelo responsável por simular o método de iluminação utilizado e a maneira como ocorrem suas resoluções matemáticas e físicas. Computa a geração ótica a partir de uma fonte de luz monocromática ou de um espectro de luz completo com base em informações inseridas através dos arquivos de AM já citados, que funcionam como perfil do espectro para a simulação. Além disso, considera valores médios para geração ótica globalmente ou feita por regiões (55). 


\section{RESULTADOS OBTIDOS}

As primeiras análises das simulações foram obtidas conforme a estrutura anexada no Apêndice (A). A partir das simulações realizadas com diodos PIN sem porta e, consequentemente, sem contato de porta e sem contato de substrato, observou-se que o comprimento da região intrínseca tem um papel fundamental nas características elétricas no que diz respeito às curvas que relacionam tensão, corrente, potência e fator de forma (FF). Este último parâmetro é indispensável para determinar a eficiência na conversão da energia absorvida, uma vez que relaciona a potência absorvida àquela que seria absorvida por um dispositivo ideal. Os resultados foram divididos em algumas etapas:

- Diodo PIN funcionando como fotodiodo com espectro monocromático para validação dos dados (56);

- Diodo PIN operando como célula solar, sem porta;

- Diodo PIN operando como célula solar, com porta, sem e com influência da temperatura.

Todos os resultados foram comparados e embasados em resultados experimentais já existentes (12) (57) (58) (59).

\subsection{DIODO PIN CONSIDERANDO UM ESPECTRO DE LUZ MONOCROMÁTICO}

Inicialmente, foram efetuadas simulações numéricas visando validar os modelos físicos utilizados. Para tal, foram utilizadas curvas experimentais apresentadas na literatura para diodos PIN funcionando como fotodetectores (56), uma vez que estes dispositivos funcionam sob luz monocromática de um comprimento de onda específico, visto que é mais fácil validar as simulações para luz de um determinado comprimento de onda do que para todo o espectro solar. Neste caso, foi gerada uma estrutura com dimensões similares às apresentadas pelo dispositivo da literatura com espessura da camada de silício de $80 \mathrm{~nm}$ sob incidência de um espectro de luz monocromático com diferentes comprimentos de onda. 
A primeira simulação utilizou-se de três comprimentos de onda para relacionar os resultados das simulações com o que se esperava em primeira instância. Foi atribuída ao dispositivo uma fina camada de silício e, por isso, a absorção de fótons se limita aos de pequenos comprimentos de onda para a geração de corrente elétrica. Este foi o comportamento observado, tendo em vista que, mantendo a potência incidente, a maior geração de corrente, foi apresentada no comprimento de onda de $0,4 \mu \mathrm{m}$. O comprimento de $1,2 \mu \mathrm{m}$, por sua vez, apresentou uma corrente irrisória mostrando relação e concordância com o que foi apresentado na figura 5 , onde é indicado que, para a absorção de comprimentos de onda superiores a $800 \mathrm{~nm}$, a camada de silício deve ter uma espessura superior a algumas dezenas de micrômetros. Na figura 20, são apresentados dados experimentais provenientes da literatura (56) juntamente com os primeiros resultados simulados, visando compará-los e validar as simulações efetuadas.

Figura 20 - Gráfico experimental para validação das simulações.

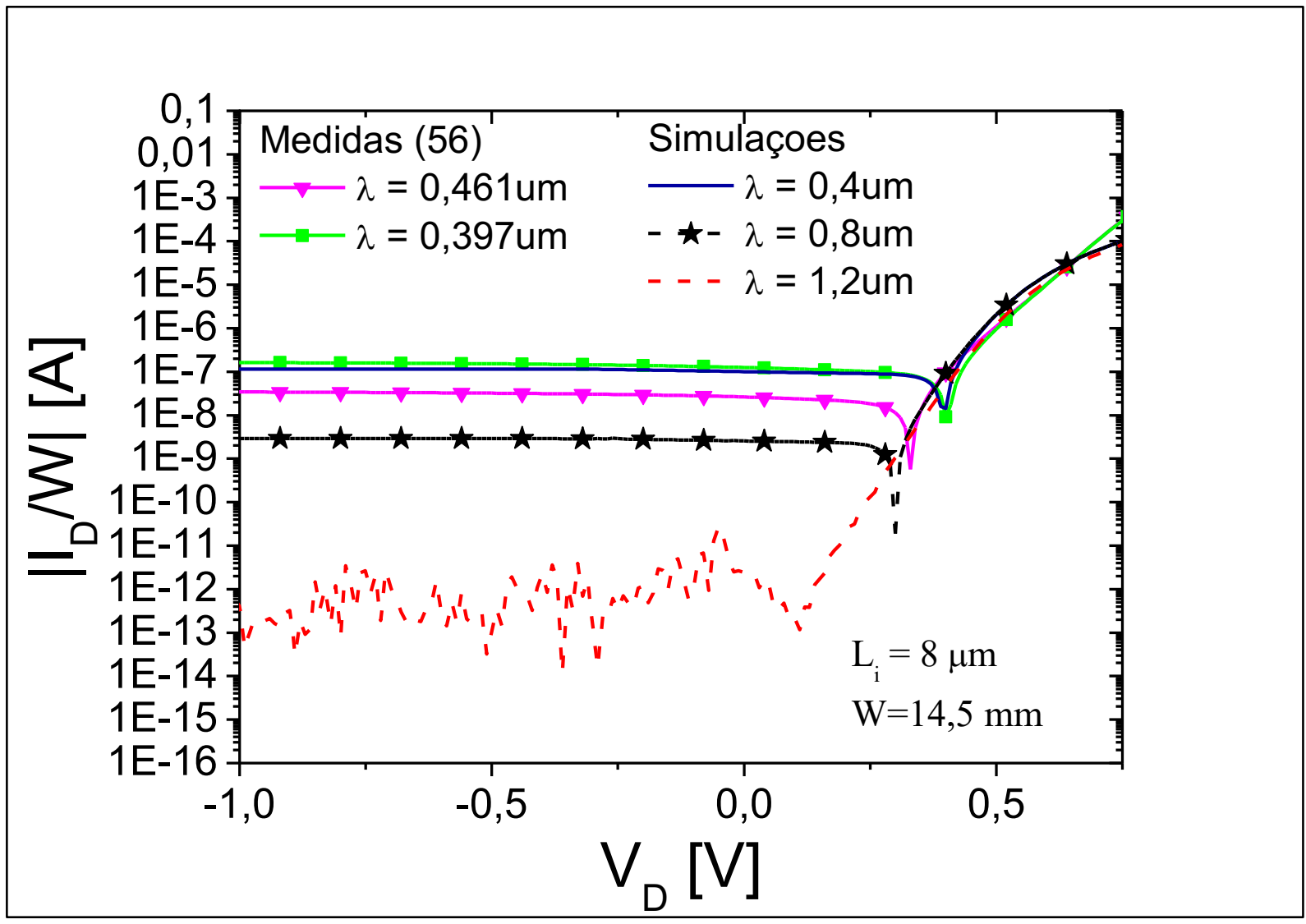

Fonte: Autoria própria. 
O gráfico apresenta curvas características de um diodo PIN experimental obtido através da Universidade Católica de Louvain, na Bélgica. Foram analisados os comportamentos em relação a diferentes comprimentos de onda e comparado às curvas de corrente simuladas, sugerindo que a curva que mais se aproximou aos experimentos foi a de $0,4 \mu \mathrm{m}$. Uma vez que o comprimento de onda utilizado para validação foi de $0,397 \mu \mathrm{m}$, o bom casamento entre as curvas medidas e as simulações mostram que as simulações efetuadas são adequadas para dar sustento ao estudo. As curvas foram normalizadas através de simulações com um dispositivo também de $8 \mu \mathrm{m}$, porém o dispositivo simulado é bidimensional, sem largura, sendo assim, seus resultados foram relacionados à largura $W=14,5 \mathrm{~mm}$ para a inserção no gráfico e posterior validação com os dados de (56) que correspondem às curvas de $0,461 \mu \mathrm{m}$ e $0,397 \mu \mathrm{m}$.

\subsection{DIODO PIN OPERANDO COMO CÉLULA SOLAR, ESTRUTURA SEM PORTA E COM ESPESSURA DE SUBSTRATO DE $80 \mathrm{~nm}$.}

Após a validação feita com espectro monocromático para verificação do dispositivo, partiu-se para novas simulações da mesma estrutura utilizada anteriormente. Entretanto, desta vez alterou-se o espectro de luz monocromático para o espectro solar, mudando o modelo de geração e resolução ótica. Em relação à pesquisa, foi escolhido mudar primeiramente o espectro simulado e, apenas na etapa seguinte, mudar a estrutura do diodo PIN simulado, modificando, em primeira instância, a espessura da camada de silício e, em seguida, trabalhando com porta e a inserção de uma fonte externa de tensão e diferentes temperaturas. Na figura 21 , são apresentadas as curvas características IxV dos dispositivos operando já com o espectro solar. 
Figura 21 - Curvas características das correntes de cada dispositivo simulado.

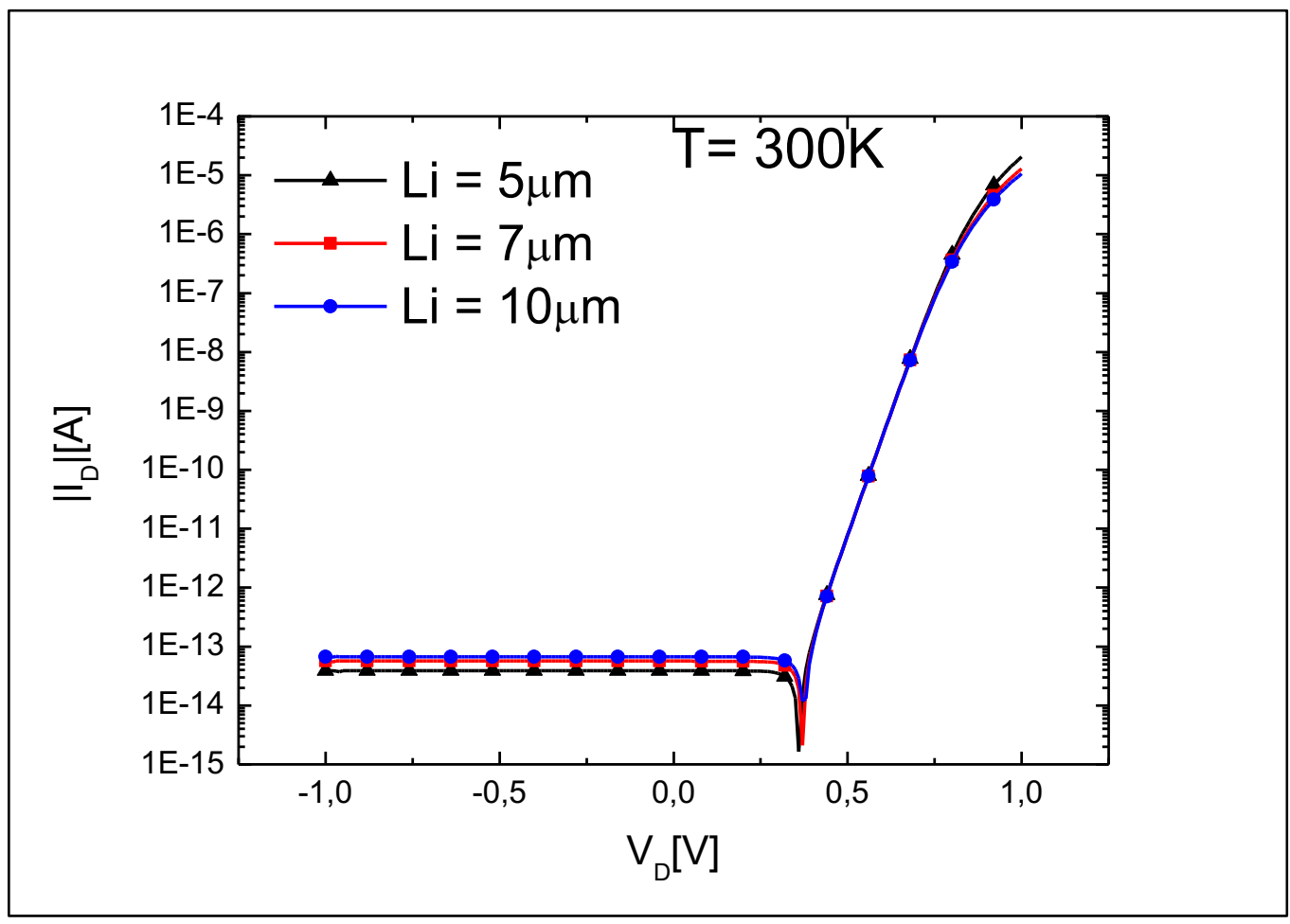

Fonte: Autoria própria, 2016.

Devido à pouca absorção decorrente da fina camada de silício, as correntes se apresentam bastante baixas, porém têm um leve aumento gradativo à medida que se aumenta o tamanho da região intrínseca e, consequentemente, o tamanho da região de depleção (59).

$\mathrm{Na}$ figura 22 são apresentadas as curvas da potência e da corrente (ID) geradas em função da tensão aplicada entre as regiões $\mathrm{P}$ e $\mathrm{N}$ de um diodo PIN com $\mathrm{Li}=20 \mu \mathrm{m}$. Tanto a curva, como os valores de potência são produtos da relação entre as tensões e correntes obtidas através da simulação. É importante ressaltar que os resultados apresentam valores negativos para consumo e positivos para geração de potência. 
Figura 22 - Curva da potência pela tensão e abaixo curva da corrente pela tensão.

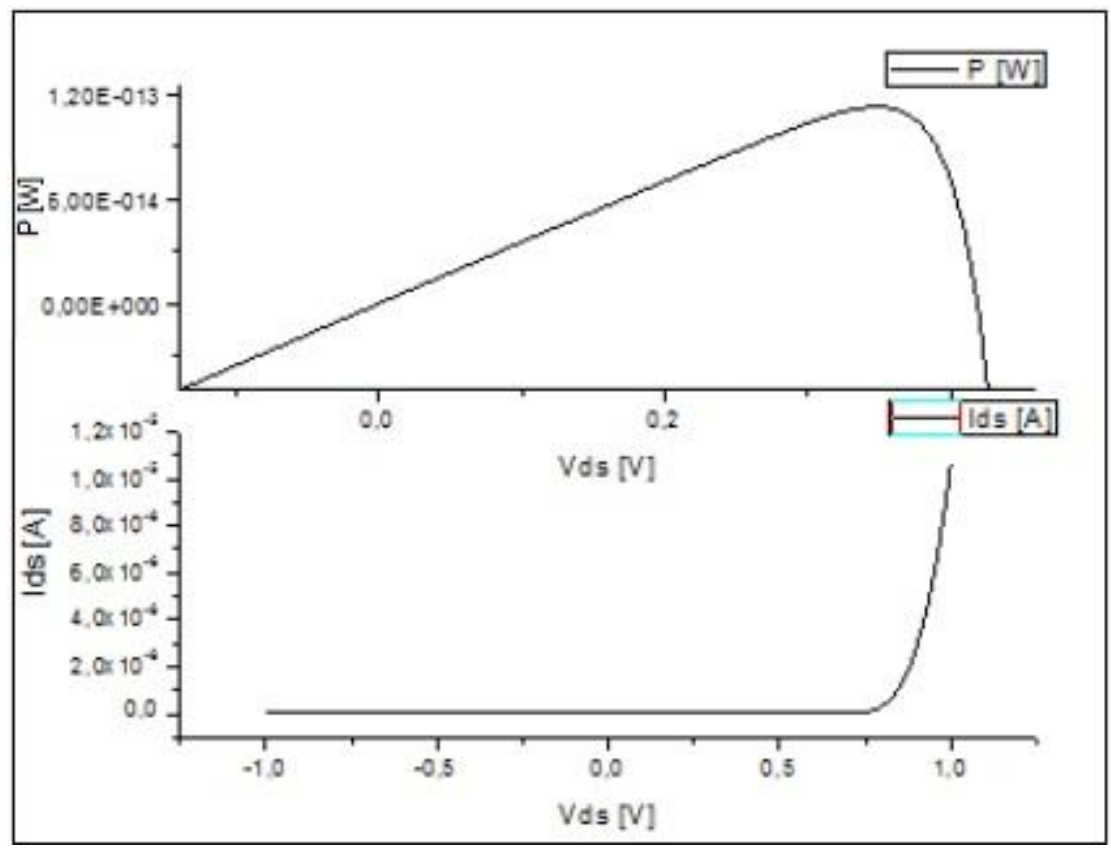

Fonte: Autoria própria.

Embora as características ID x VD dos dispositivos tenham sido obtidas para uma faixa de tensão de $-1 \mathrm{~V}$ a $1 \mathrm{~V}$, a potência só é positiva para a faixa entre $-0,12 \mathrm{~V}$ e $0,42 \mathrm{~V}$ (figura 22, gráfico superior), indicando que, fora deste intervalo, os diodos PIN consomem mais energia que geram. A partir da curva superior, pode-se extrair o par corrente-tensão para o qual temos os valores de potência máxima gerada pelo dispositivo. Com o intuito de se obter o fator de forma, podemos extrair do segundo gráfico a máxima potência fornecida por um dispositivo ideal, dada pela tensão de circuito aberto (Voc), obtida quando o diodo apresenta corrente igual a zero, multiplicada pela menor corrente obtida na polarização reversa (extraída para VD = 1 V). Como mencionado na seção 3.2.2, a razão da potência máxima fornecida pelo dispositivo pela potência máxima de um dispositivo ideal, constitui seu fator de forma.

Na Figura 23, são apresentadas as curvas do fator de forma e da potência máxima dos dispositivos simulados em função do comprimento da região intrínseca. De acordo com os dados, pode-se notar que o aumento da potência máxima dos dispositivos é contínuo com o aumento do comprimento Li. 
Figura 23 - Curva relacionando potência máxima e fator de forma com o comprimento intrínseco para um diodo PIN com espessura de substrato de 80 nanômetros.

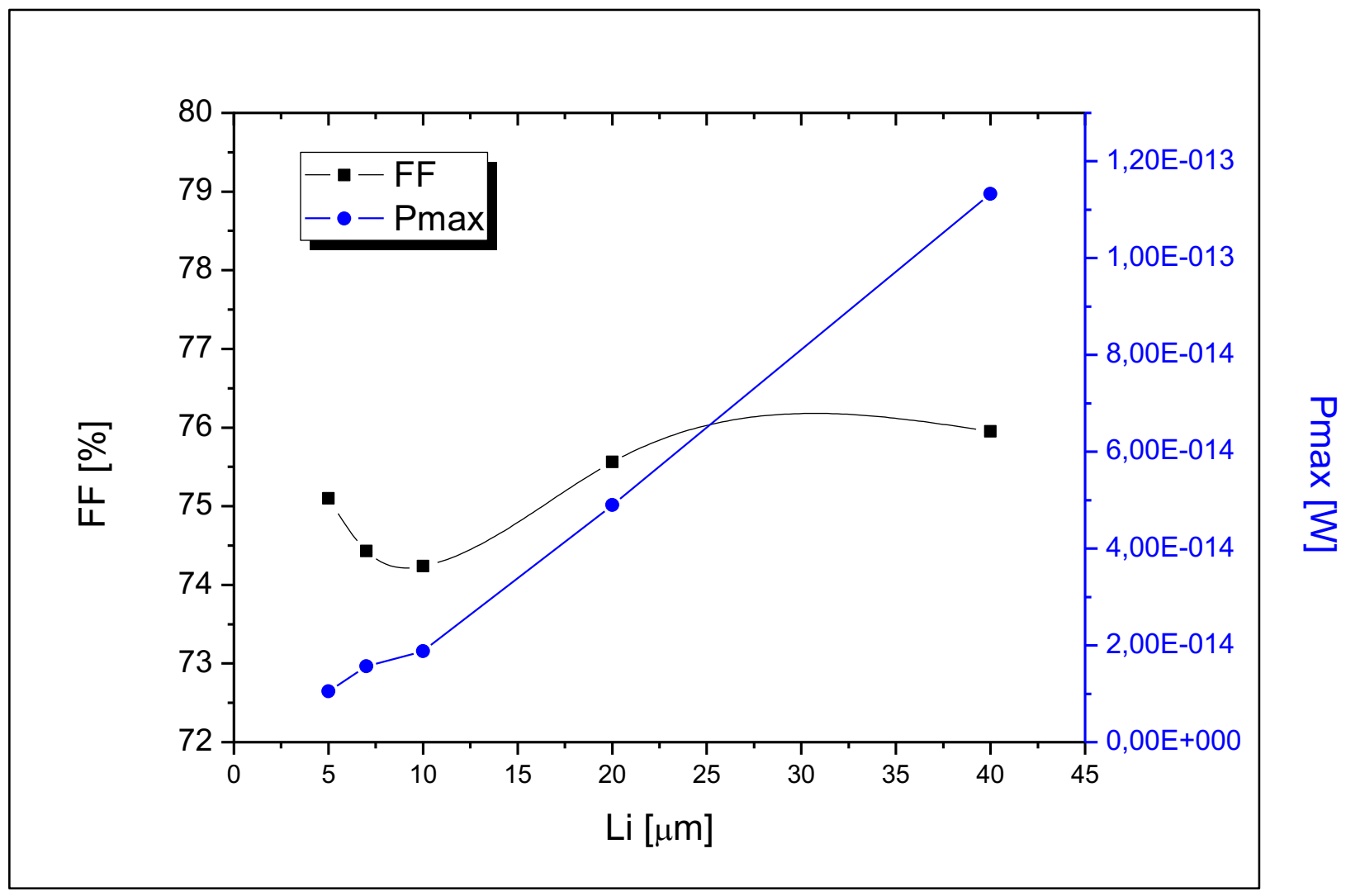

Fonte: Autoria própria.

Esta primeira estrutura simulada serviu de base para concretizar o estudo e comprovar o funcionamento do diodo PIN como célula solar, visto que no intervalo de $V_{D}$ entre $-0,12 \mathrm{~V}$ e $0,42 \mathrm{~V}$, o dispositivo gera mais energia que consome. No caso dos dispositivos estudados, observou-se um máximo FF de $75 \%$ para o diodo PIN com $\mathrm{Li}=20 \mu \mathrm{m}$. Este valor se equipara aos $75 \%$ apresentados em (12) para uma célula de dimensões similares. A princípio, esta primeira estrutura simulada, não é a mais adequada para se trabalhar como célula solar devido à fina espessura da camada de silício. Entretanto, houve a necessidade de uso da mesma para a validação dos dados experimentais utilizados como referência. Sendo assim, o rendimento destas primeiras estruturas operando como células solares é extremamente baixo, na ordem de $1,8 \times 10^{-4}$. A fina camada de silício influencia diretamente na absorção do espectro solar, que é irrisória para a liberação de fótons e, consequentemente, geração de portadores de carga pelo efeito fotovoltaico. 


\subsection{DIODO PIN FUNCIONANDO COMO CÉLULA SOLAR CONSIDERANDO ESPESSURA DO SUBSTRATO DE $2 \mu \mathrm{m}$, ESTRUTURA SEM PORTA.}

Posteriormente, se fez uma nova estrutura totalmente adequada para o diodo PIN operar como célula solar. O primeiro passo foi aumentar a espessura da camada de silício simulada de $80 \mathrm{~nm}$ para $2 \mu \mathrm{m}$, valor estabelecido também em relação aos dispositivos com quais já se obteve resultados concretos, assim como consta em (12). O valor de $2 \mu \mathrm{m}$, considerado para a espessura da camada de silício é o mínimo suficiente para absorver boa parte do espectro de luz emitido pelo Sol, como pôde ser constatado através de (12). Ao se utilizar a espessura de $2 \mu \mathrm{m}$ ao invés de espessuras maiores, reduz-se sensivelmente o tempo das simulações. Estas simulações também foram realizadas acerca de muitos valores para o comprimento $\mathrm{Li}$, buscando resultados mais próximos daqueles esperados para uma célula solar experimental.

O primeiro ponto a se observar nestas novas simulações é a alteração das características elétricas apresentadas, o que leva a pesquisa novamente às curvas ID $\times$ VD.

Foram analisadas as curvas ID $\times$ VD características de dispositivos com sete comprimentos Li diferentes, sendo eles 1, 5, 8, 12, 15, 18 e $22 \mu \mathrm{m}$. Na Figura 24, observa-se o gráfico elaborado que permite a visualização da corrente total que flui no dispositivo em função da tensão aplicada. Como se pode observar na figura, ao se aumentar a espessura da camada de silício, há um grande aumento na corrente em estado desligado, como se pode comprovar ao confrontar as curvas da figura 24 com aquelas apresentadas na figura 21. Este aumento pode chegar a cerca de 5 ordens de magnitude e se deve a uma melhor absorção dos comprimentos de onda compreendidos entre 350 e 650 nanômetros, os quais englobam a região de máxima potência do espectro AM1.5, cuja absorção é importante para a operação de células solares. 
Figura 24 - Curvas de tensão pela corrente em escala logarítmica dos dispositivos simulados, separados pelo comprimento intrínseco.

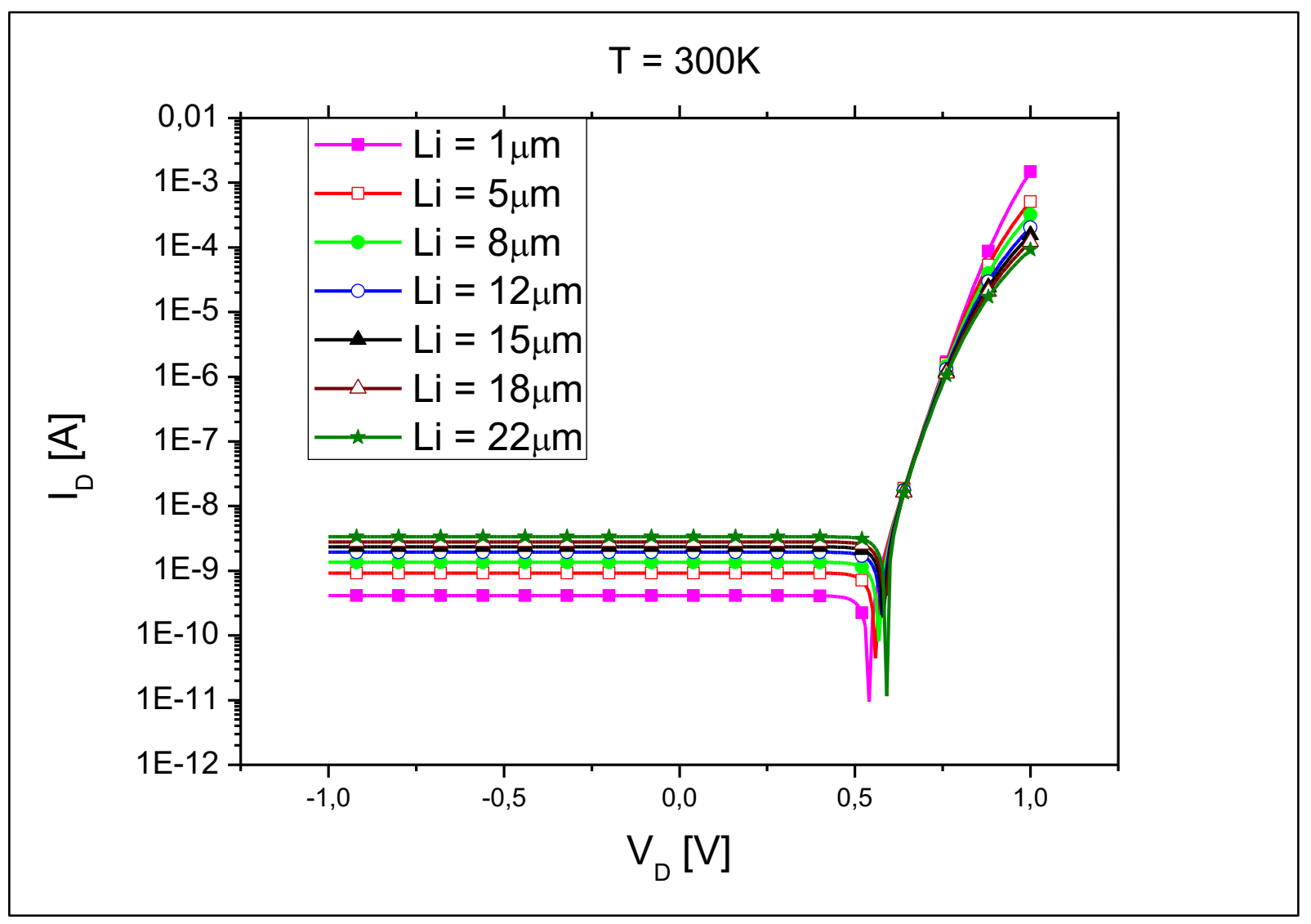

Fonte: Autoria própria.

Com base no gráfico, pode-se observar o perfil da curva da tensão pela corrente traçado a partir da região $\mathrm{P}$ do diodo PIN. É possível verificar que Id aumenta gradativamente com o aumento do comprimento intrínseco, o que, consequentemente, gera um aumento na potência de saída do dispositivo como se pode observar na figura 25. Afirma-se também que o ponto de ativação do diodo (ou sua polarização direta), se dá à direita da região indicada por uma queda repentina da corrente. Devido a curva estar representada pela forma logarítmica da corrente Id, na verdade não existe queda de corrente, mas é a partir deste ponto que os valores de corrente e potência que até então, eram negativos, passam a ser positivos. Este limiar ocorre entre 0,5 e $0,6 \mathrm{~V}$ em todas as simulações e é a denominada tensão de circuito aberto (Voc). Como já mencionado anteriormente, esta tensão indica exatamente onde o circuito passa da condição de consumidor da eletricidade para fornecedor. 
A partir das tensões e correntes de cada dispositivo simulado, deu-se prosseguimento na análise de dados, agora com o cálculo e verificação tanto da potência máxima absorvida (Pmax), como da potência incidente (Pin). A seguir são apresentadas as curvas dessas duas potências abordadas.

Figura 25 - Gráfico de potência máxima e potência incidente para um diodo PIN com espessura de substrato de $2 \mu \mathrm{m}$.

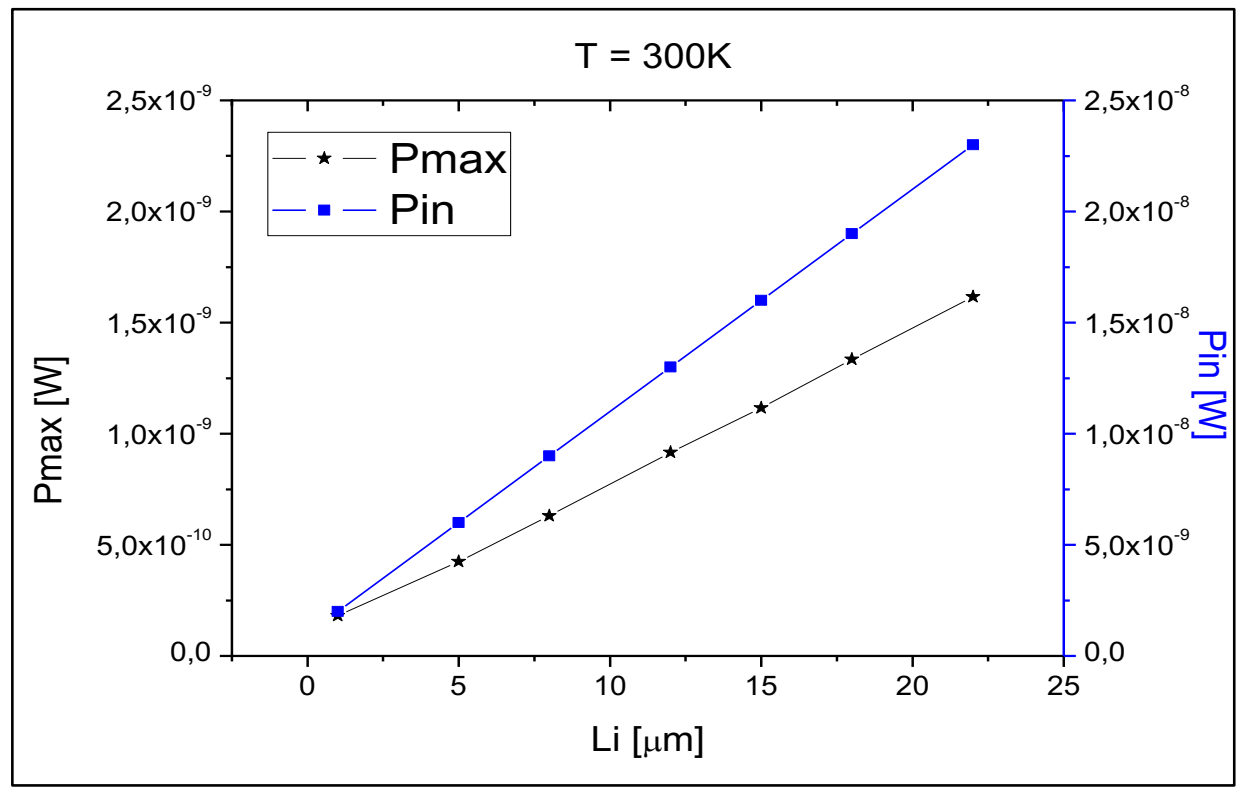

Fonte: Autoria própria.

Tanto a potência máxima quanto a potência incidente, Pmax e Pin, respectivamente, apresentam aumento juntamente com 0 aumento da região intrínseca. Isso significa que, quanto maior é a área do dispositivo, mais energia ele recebe. Por um lado, isso é ótimo, pois o rendimento da célula é dependente de ambas as potências. Porém, para o rendimento e o fator de forma esse aumento significa apenas dispersão e difusão maior da energia dos fótons, reduzindo o rendimento da célula juntamente com seu fator de forma, como pode ser observado na figura 27, onde são apresentados o fator de forma e o rendimento em função do comprimento da região intrínseca para os dispositivos estudados. Este comportamento indica que uma área muito grande não pode ser bem aproveitada. Concluindo que uma quantidade menor de fótons conseguirá gerar portadores que participem do fluxo elétrico para uso posterior. 
No entanto, antes de verificar o fator de forma é preciso analisar os parâmetros dos quais ele depende, assim como as potências foram analisadas antes do rendimento, as tensões de circuito aberto e correntes de curto circuito podem ser observadas na figura 26.

Figura 26 - Curvas de Voc (tensão de circuito aberto) e Isc (corrente de curto circuito) e seus comportamentos.

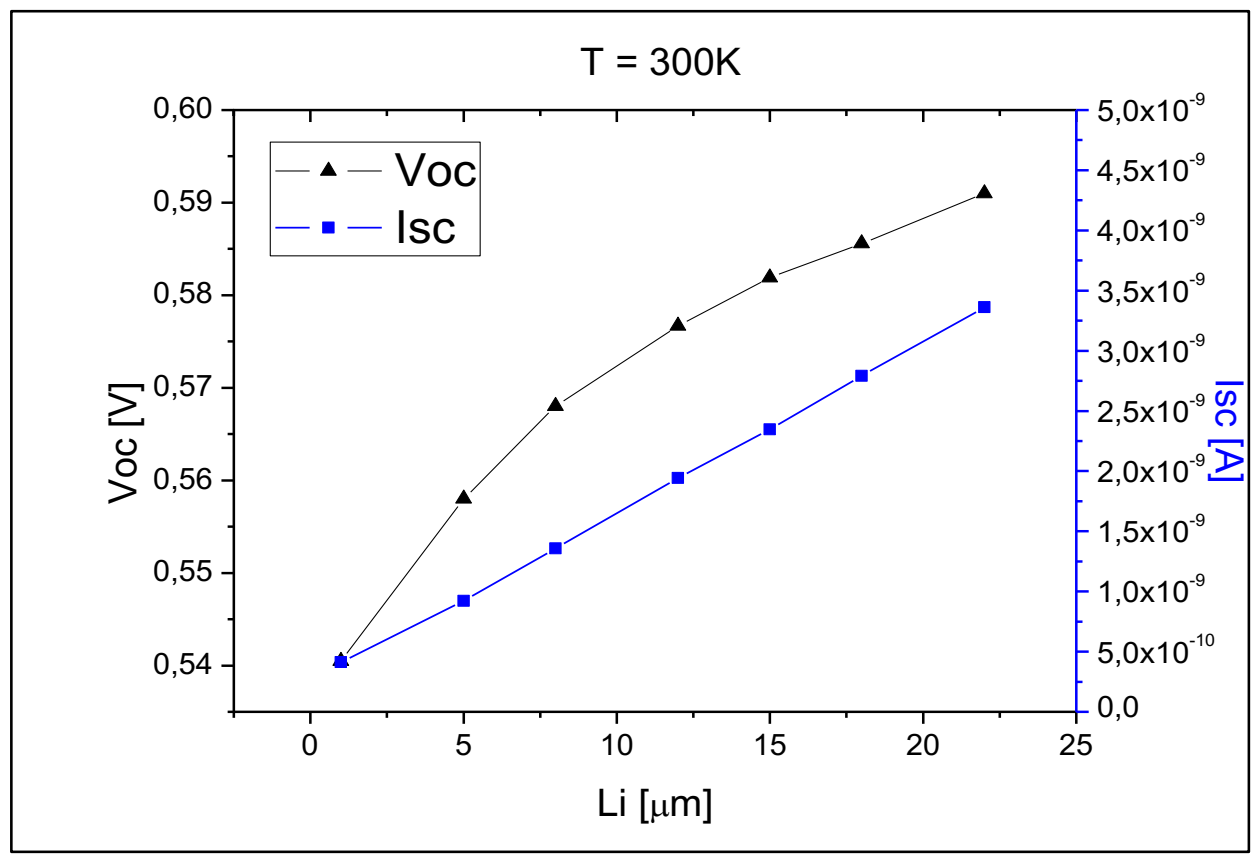

Fonte: Autoria própria.

O primeiro fato a se analisar é que o comportamento de Voc aumenta com $\mathrm{L}_{\mathrm{i}}$, embora a taxa de aumento seja menor para maiores $L_{i}$. Este fato está relacionado ao funcionamento do diodo PIN em relação ao comprimento de difusão (37), conforme pode ser notado mais claramente na figura 27 , que trata do fator de forma e do rendimento da célula solar.

Como pode ser observada na figura 27, uma queda significativa no rendimento da célula é observada com o aumento do comprimento da região intrínseca dos dispositivos. Com relação ao fator de forma, o mesmo aparenta um incremento com o comprimento intrínseco até $\mathrm{Li}$ da ordem de $8 \mu \mathrm{m}$ e reduz para $\mathrm{L}_{\mathrm{i}}$ maiores. O fator de forma mantém da ordem de $80 \%$ a $82 \%$ para todos os $L_{i}$ analisados. 
Figura 27 - Gráfico sobre fator de forma e rendimento dos dispositivos já simulados e apresentados.

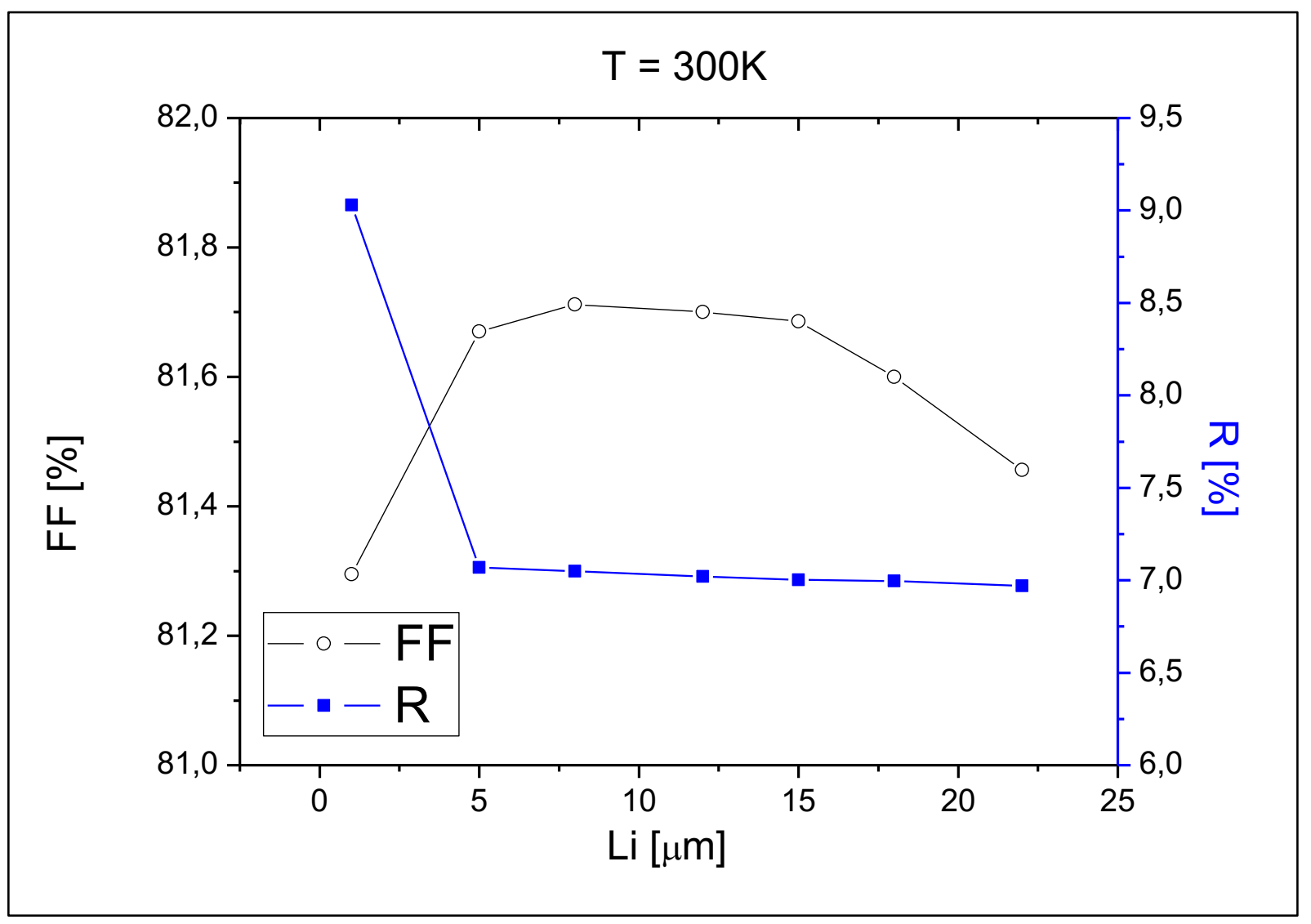

Fonte: Autoria própria.

Este comportamento está relacionado com a quantidade de portadores gerados na região de depleção e sua eficiência em atravessar a região intrínseca em direção às regiões $\mathrm{P}$ e $\mathrm{N}$. Para pequenos $\mathrm{Li}$, é gerada uma menor quantidade de portadores devido ao menor comprimento da região de depleção. Com o aumento de $L_{i}$ até $8 \mu \mathrm{m}$ se nota um leve aumento no fator de forma, o que compreende um aumento nos valores de Voc e Isc, e para $L_{i}$ maiores, ele volta a cair gradativamente. Conforme o comprimento intrínseco aumenta, parte dos portadores passa a se recombinar ainda no interior da região intrínseca, não contribuindo para a corrente total do dispositivo, o que reduz Li. Este esfeito está associado ao comprimento de difusão dos portadores que é da ordem de $9 \mu \mathrm{m}$.

Através dos dados obtidos dos arquivos de saída das simulações, foi feita uma tabela 1 explicitando os valores, apresentados nas figuras 26 e 27 respectivamente, calculados de Potência máxima (Pmáx), Potência de entrada (Pin), 
fator de forma e rendimento, que tem relação direta com a área do dispositivo e tensão de circuito aberto (Voc), aspectos citados anteriormente.

Tabela 1 - Relação entre os comprimentos intrínsecos e os valores extraídos.

\begin{tabular}{l|cccccc}
$\begin{array}{l}\text { Comprimento } \\
\text { Li }\end{array}$ & Pmáx (W) & Pin (W) & Voc (V) & Isc (A) & FF (\%) & $\begin{array}{c}\text { Rendimento } \\
\text { (\%) }\end{array}$ \\
\hline $01 \mu \mathrm{m}$ & $1,80702 \mathrm{E}-10$ & $2 \mathrm{E}-9$ & 0,576 & $4,11273 \mathrm{E}-10$ & 81,295 & 9,03 \\
$05 \mu \mathrm{m}$ & $4,24065 \mathrm{E}-10$ & $6 \mathrm{E}-9$ & 0,558 & $9,22627 \mathrm{E}-10$ & 81,67 & 7,07 \\
$08 \mu \mathrm{m}$ & $6,30501 \mathrm{E}-10$ & $9 \mathrm{E}-9$ & 0,568 & $1,35852 \mathrm{E}-9$ & 81,712 & 7,05 \\
$12 \mu \mathrm{m}$ & $9,15349 \mathrm{E}-10$ & $1,3 \mathrm{E}-8$ & 0,5767 & $1,94269 \mathrm{E}-9$ & 81,7 & 7,021 \\
$15 \mu \mathrm{m}$ & $1,11533 \mathrm{E}-9$ & $1,6 \mathrm{E}-8$ & 0,5919 & $2,34642 \mathrm{E}-9$ & 81,686 & 7,002 \\
$18 \mu \mathrm{m}$ & $1,33426 \mathrm{E}-9$ & $1,9 \mathrm{E}-8$ & 0,5856 & $2,79224 \mathrm{E}-9$ & 81,6 & 6,9978 \\
$22 \mu \mathrm{m}$ & $1,61654 \mathrm{E}-9$ & $2,3 \mathrm{E}-8$ & 0,5901 & $3,36306 \mathrm{E}-9$ & 81,456 & 6,97
\end{tabular}

Fonte: Autoria própria.

Os cálculos realizados demonstram que se conseguem maiores potências, tensões e correntes à medida que se eleva o valor de Li. Quanto mais se aumenta o comprimento intrínseco menor é o rendimento obtido. Tendo em vista que a corrente total aumenta, a sua perda é mais significativa com comprimentos maiores, pois essa característica dificulta o fluxo elétrico e facilita a ocorrência dos efeitos de recombinação dos elétrons por estes precisarem de mais energia para percorrer um caminho mais longo até o terminal do dispositivo. Em relação ao fator de forma, pode-se dizer que ele está dentro de um bom alcance e possuem valores da ordem de $80 \%$. Porém, os dispositivos simulados até aqui não possuem uma porta para operação como célula solar. Sabendo-se que a presença de uma porta pode aumentar e eficiência de uma célula solar conforme descrito em (13) (59), foram simulados dispositivos com porta visando comparar seus resultados com os vistos até este momento.

\subsection{DISPOSITIVOS PIN SOI CONSIDERANDO A ESPESSURA DO SUBSTRATO DE $2 \mu \mathrm{m}$ COM PORTA}

Os dispositivos com porta permitem controlar e estabilizar o dispositivo alvo, possibilitando aplicar a ele uma fonte de tensão externa a fim de alterar seu comportamento em relação ao controle das cargas devido ao campo elétrico gerado junto à região de depleção. Este maior controle se traduz em aumento de corrente, 
eficiência quântica e potência, possibilitando melhora no desempenho, porém também aumenta o efeito de recombinação. Várias medidas de Li foram acrescidas para melhor observação, além de um diodo PN também fabricado na tecnologia SOI e com porta. Neste caso, foi reduzida a medida do comprimento intrínseco até que não se tivesse mais esta região $\left(L_{1}=0 \mu \mathrm{m}\right)$ para uma comparação mais ampla e adequada de resultados. Para estas simulações foi assumido um óxido de porta de 30 nanômetros em acordo com a medida oriunda dos dispositivos adquiridos em convênio com a Universidade Católica de Louvain, Bélgica, já citado e utilizado para validação dos estudos.

A porta utilizada na estrutura simulada com fonte de tensão externa apresentou um aumento nas correntes, porém a tensão de $5 \mathrm{~V}$ não foi relevante para as grandezas mencionadas, inclusive manteve a mesma média de tensão de limiar dos dispositivos sem porta, cerca de 0,57V. Como é de praxe, os primeiros dados extraídos das simulações são as curvas ID x VD, neste ponto serão analisadas as curvas para os dispositivos com porta com tensão nula e tensão de porta $\mathrm{Vg}=5 \mathrm{~V}$. Verificam-se, na figura 28 e 29, as respectivas curvas para vários comprimentos intrínsecos.

Figura 28 - Curvas características dos dispositivos com tensão nula.

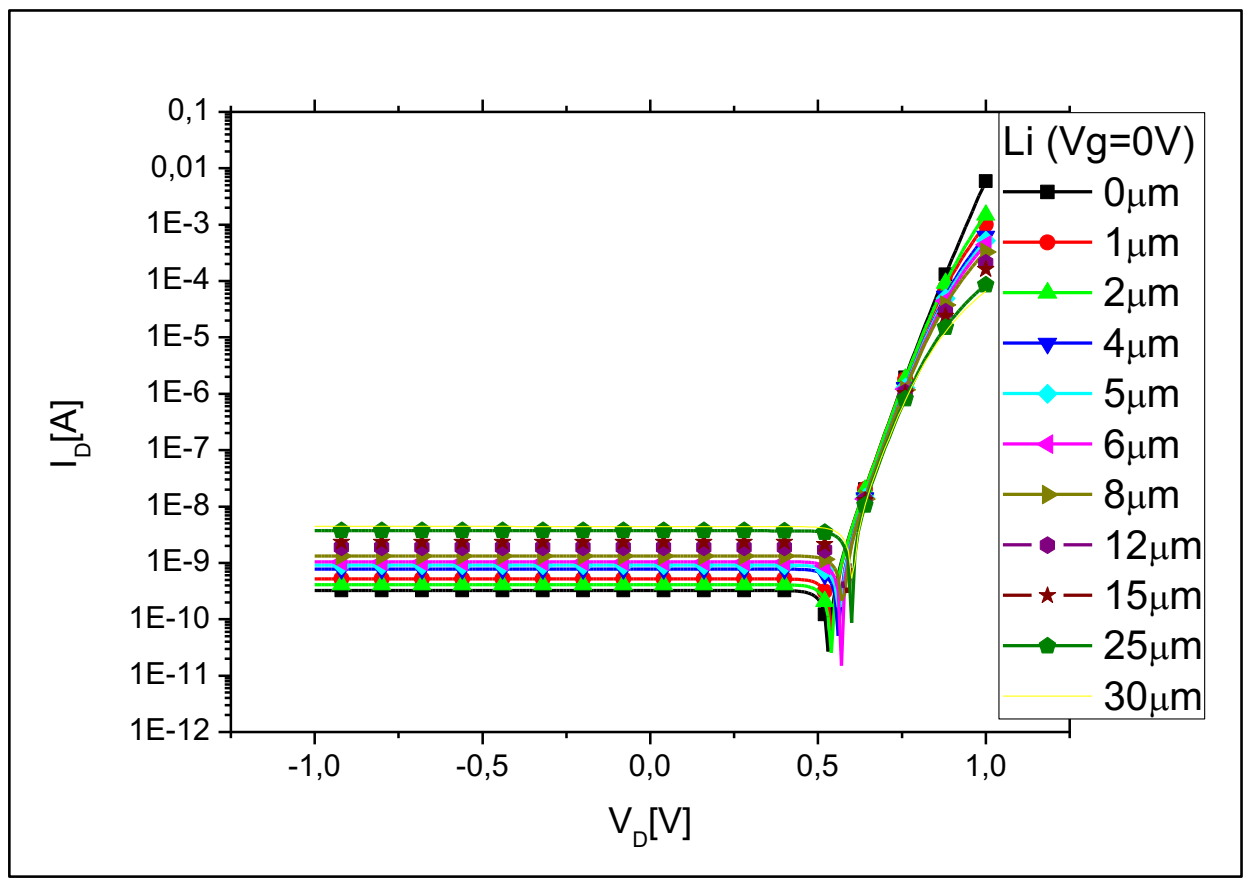

Fonte: Autoria própria. 
Figura 29 - Curvas características para tensão $\mathrm{Vg}=5 \mathrm{~V}$.

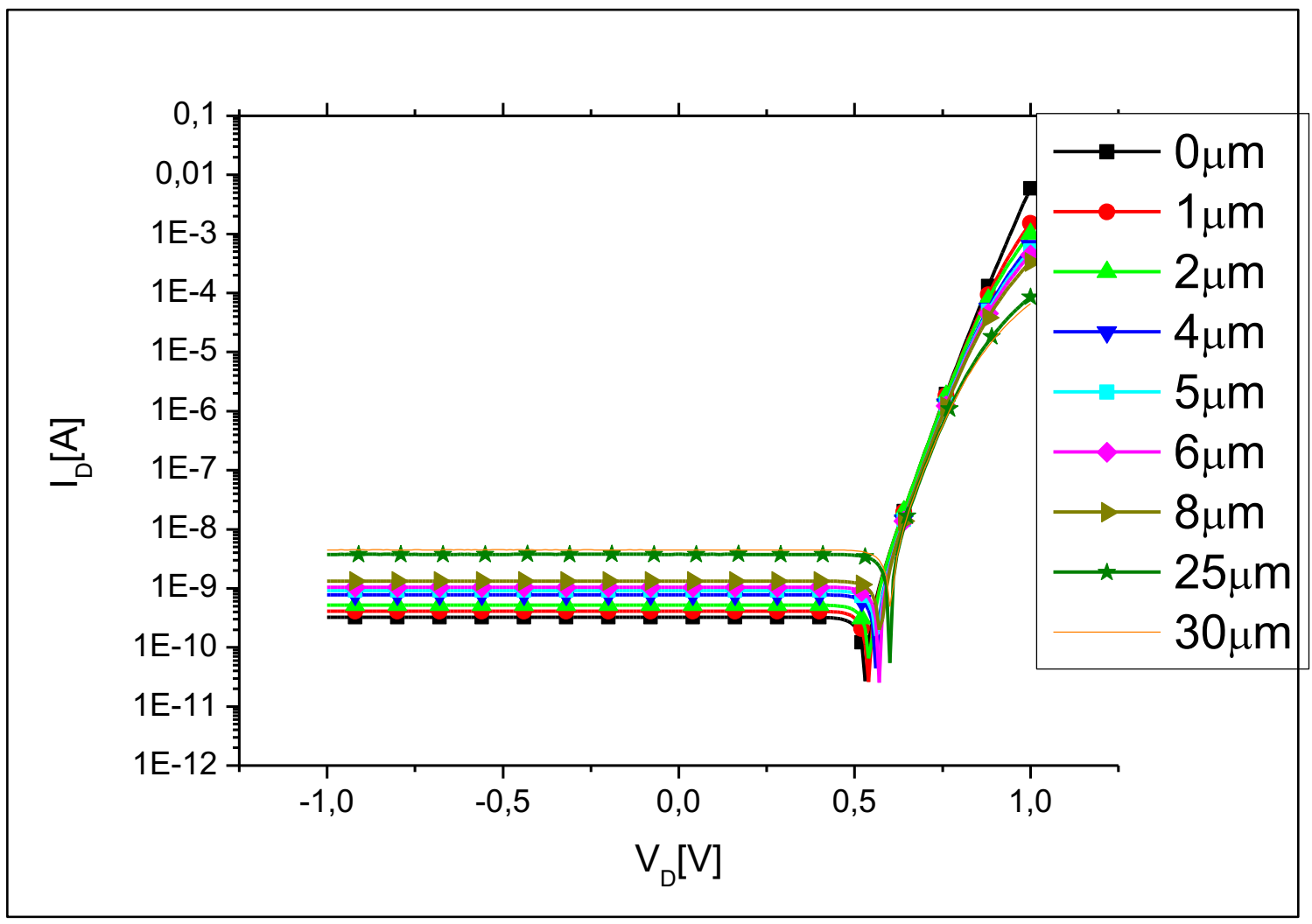

Fonte: Autoria própria.

O que se vê nos gráficos das figuras 28 e 29 e pode ser comprovado pela extração dos dados simulados de corrente, é que o aumento de 5 volts na tensão do sistema da célula é insignificante, deixando as curvas com pouca alteração nos valores, a exemplo disto temos que a corrente para $\mathrm{Li}=30 \mu \mathrm{m} \mathrm{Vg}=0 \mathrm{~V}$ no ponto onde $\mathrm{VD}=1 \mathrm{~V}$ é igual a $6,60607 \mathrm{E}-5 \mathrm{~A}$ e enquanto para $\mathrm{Vg}=5 \mathrm{~V}$ este mesmo ponto da corrente é igual a $6,60821 \mathrm{E}-5 \mathrm{~A}$. Tendo em vista que a diferença da tensão pouco influenciou na corrente, observa-se em seguida as potências dos dispositivos. 
Figura 30 - Relação potências e comprimentos intrínsecos dos dispositivos com tensão nula e 5 volts.

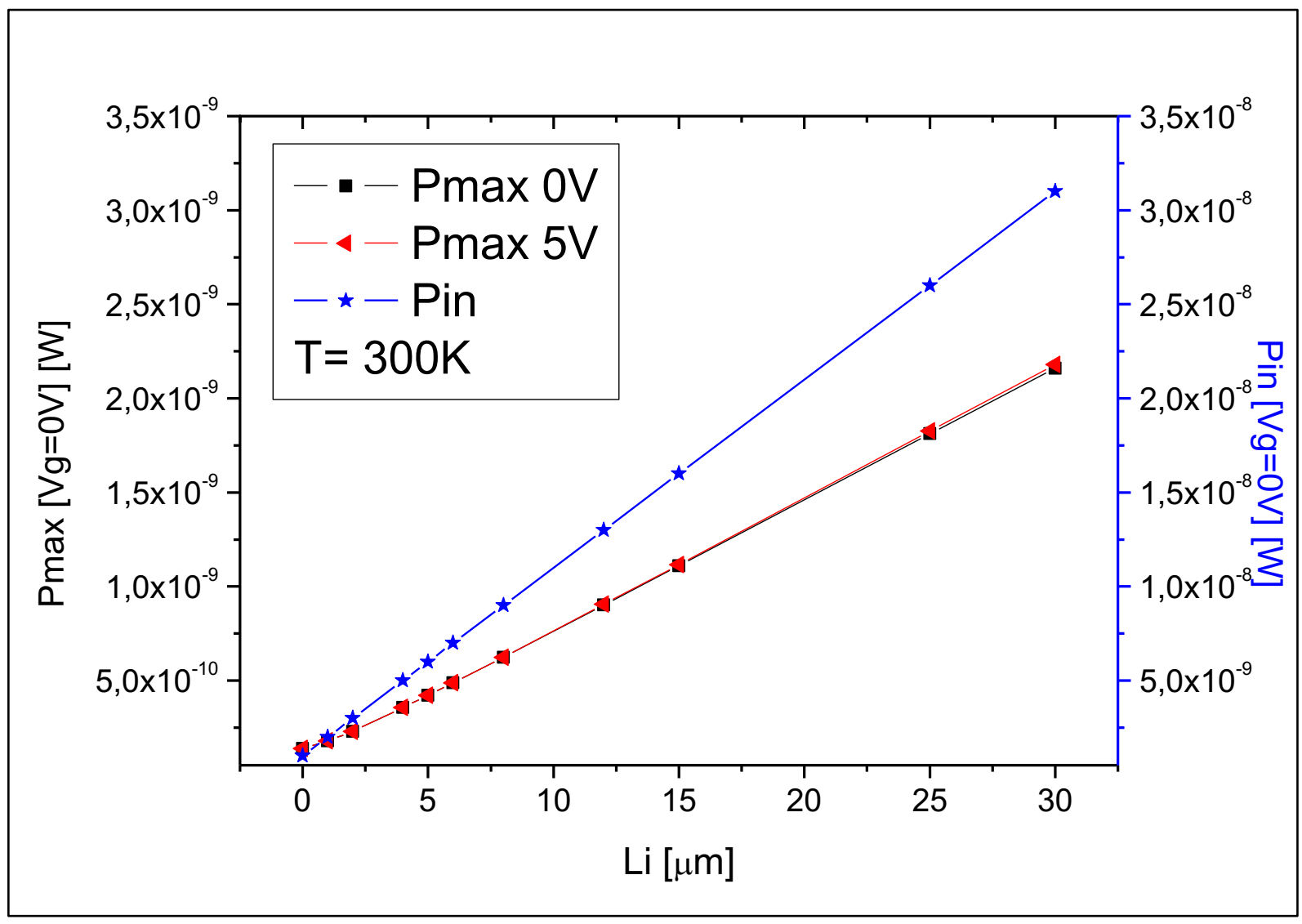

Fonte: Autoria própria.

Pode se iniciar a análise do gráfico acima lembrando que a potência incidente (Pin) depende apenas da potência do espectro solar estabelecida pela NASA e da área do dispositivo, ela se mantém inalterada mesmo com alteração da tensão. $A$ diferença entre a potência incidente e a máxima gerada no dispositivo é sempre próximo a uma ordem de grandeza. Comparando os valores de potência máxima, pode-se observar que a intensidade de tensão (5 volts) não altera significativamente seu valor.

Nas figuras 31 e 32 são apresentados, respectivamente, a tensão de circuito aberto e a corrente de curto-circuito em função do comprimento intrínseco para diodos PIN com polarizações de porta $(\mathrm{Vg})$ de 0 e $5 \mathrm{~V}$. 
Figura 31 - Tensão de circuito aberto "Voc" relacionada ao comprimento intrínseco.

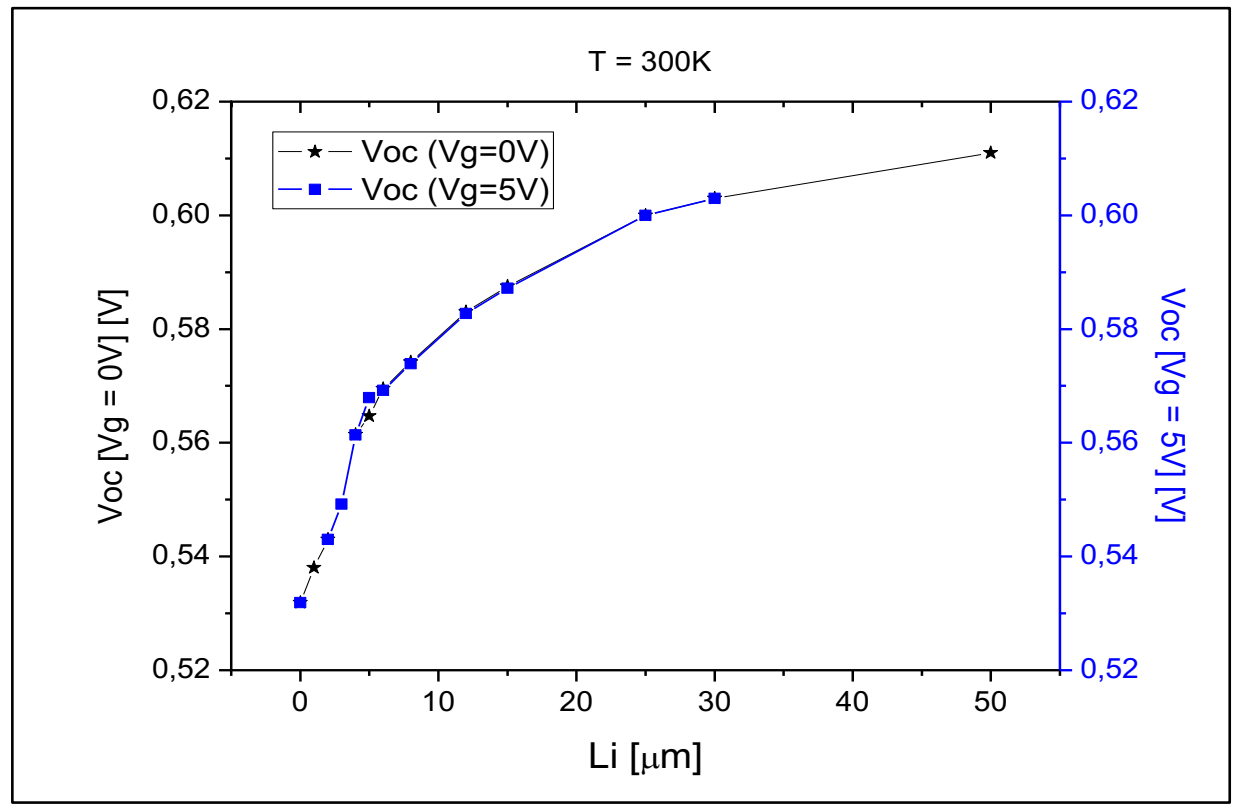

Fonte: Autoria própria.

Figura 32 - Relação Corrente de curto circuito "Isc" com Li.

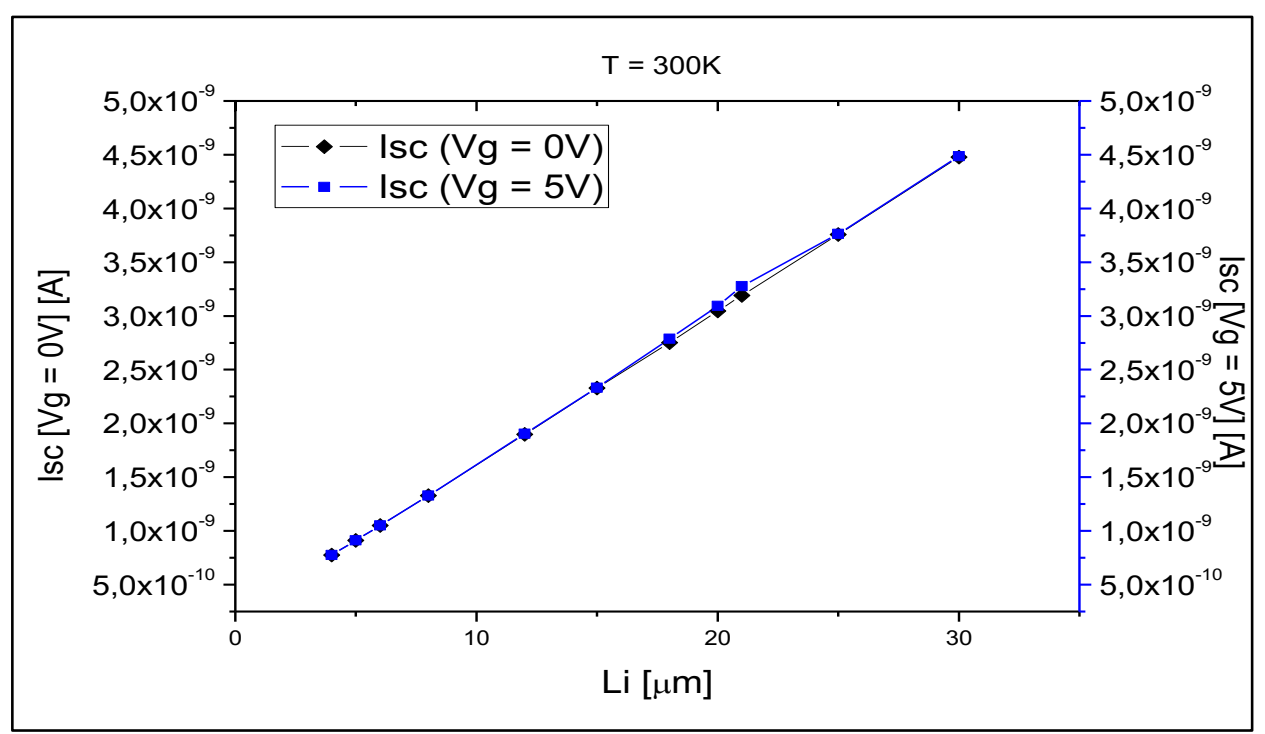

Fonte: Autoria própria.

Tanto a tensão de circuito aberto como a corrente de curto-circuito têm aumento significativo a partir do tamanho do comprimento intrínseco. Comparando estes resultados com os dispositivos sem porta, é observada uma grande similaridade nas correntes e tensões. Confirmando que baixas tensões externas não têm influência quanto ao princípio de funcionamento das células solares. As curvas 
para 0 e 5 volts estão sobrepostas para todos os $\mathrm{Li}$ estudados, reforçando os comentários acima.

Analisado todos os parâmetros extraídos das simulações, calculou-se os valores de rendimentos e fatores de forma dos diodos com porta metálica.

Elaborou-se a curva de rendimento e fator de forma obtidos na simulação com porta e tensão $\mathrm{Vg}=5 \mathrm{~V}$. Observa-se que, na figura 33, são apresentadas as curvas dos rendimentos e fatores de forma em função do comprimento intrínseco das simulações para diodos com porta polarizada com 0 e $5 \mathrm{~V}$ para visualizar e comparar ambos os resultados.

Figura 33 - Curvas de rendimento e fator de forma em relação ao comprimento intrínseco do primeiro dispositivo com porta, ambas as polarizações (0 e 5V).

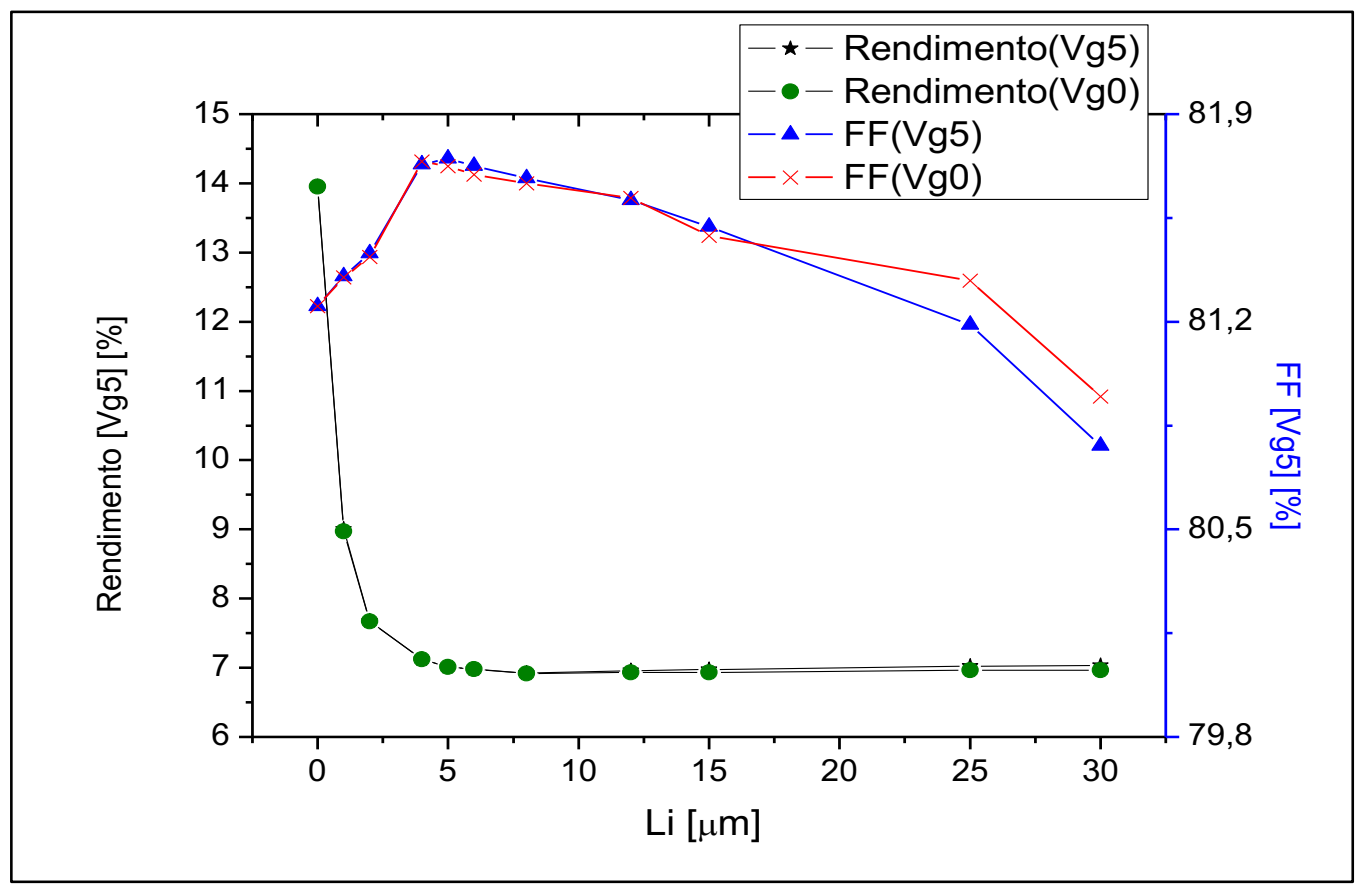

Fonte: Autoria própria.

As curvas da figura 33 expressam de forma clara que não há alteração significativa no rendimento ao se aumentar a tensão de porta de 0 para $5 \mathrm{~V}$. No caso do fator de forma, percebe-se que o aumento de tensão de porta não proporciona nenhuma alteração com o aumento de Li até $7 \mu \mathrm{m}$. Para Li maiores, existe um pequeno incremento no fator de forma ao se aplicar $\mathrm{Vg}=5 \mathrm{~V}$, que pode chegar a 1 $\%$ para $\mathrm{Li}=30 \mu \mathrm{m}$. Esta diferença deve ser mais contundente quando se possui um 
substrato mais espesso e tensão de porta maior que 20 volts (12), importante para a pesquisa em foco, porém não se adequa a idealização de um sistema autônomo.

Seguem, na figura 34, as curvas dos resultados e comparações em relação aos diodos sem porta. As taxas de consumo de potência são maiores dos diodos com porta em relação a do dispositivo sem porta, o que ocasiona rendimento levemente menor, apesar do incremento da potência gerada devido ao aumento em Isc. Com relação ao fator de forma, tanto os dispositivos com porta como os sem porta apresentam resultados similares.

Figura 34 - Comparação dos resultados entre dispositivo sem porta e dispositivo com porta e tensão nula.

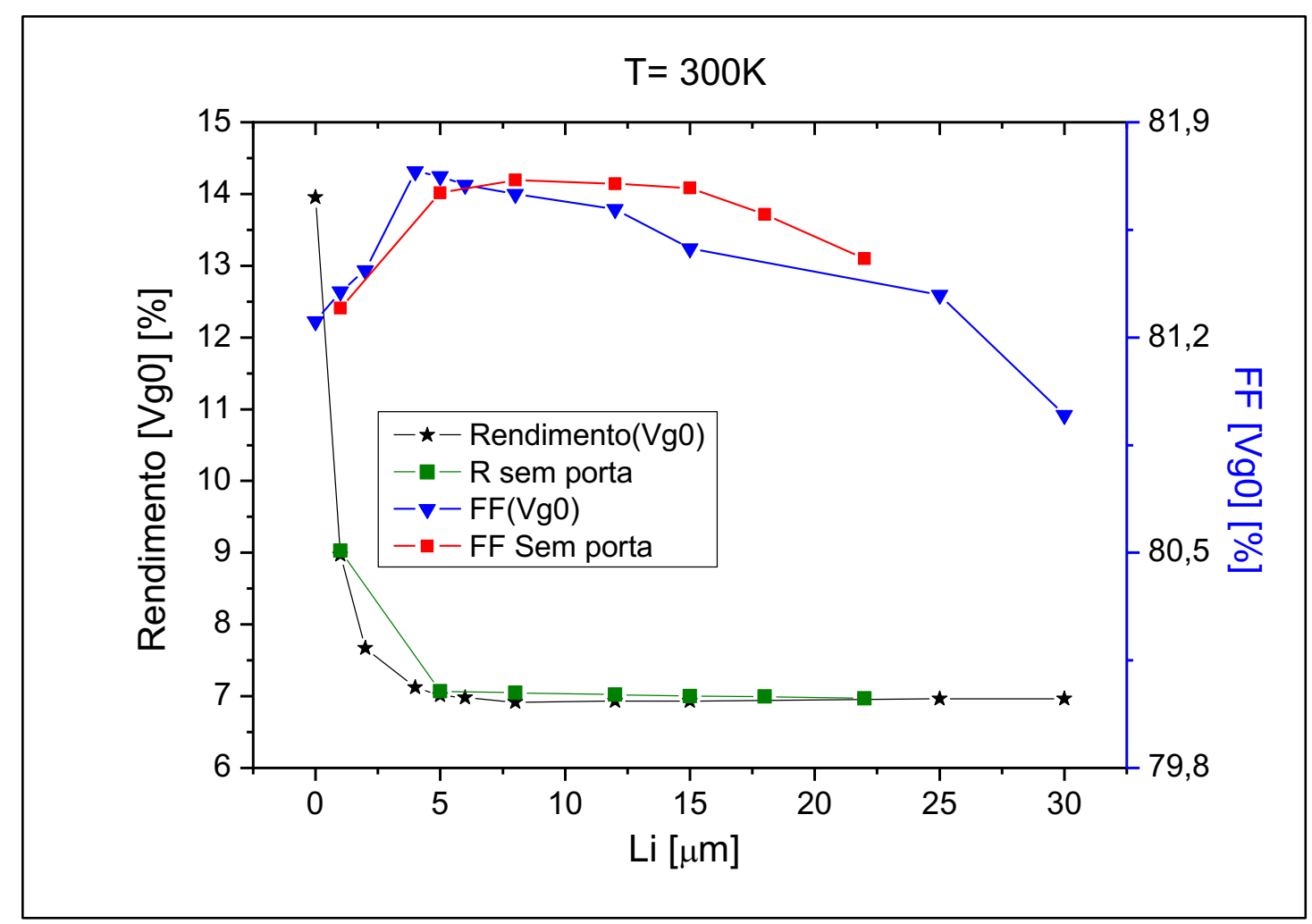

Fonte: Autoria própria.

Através da comparação feita e observada no gráfico acima, a inserção da porta com baixa tensão quase não alterou o comportamento da célula solar.

O que se pode concluir é que, em ambos os dispositivos, o rendimento possui uma queda exponencial com o aumento da região intrínseca. Quanto ao fator de forma, este possui um leve aumento com a inserção de uma região intrínseca, 
porém já demonstra queda com comprimentos maiores que 7 micrômetros. Como já mencionado, este fenômeno se explica pelo comprimento de difusão dos elétrons (37). Eles começam a se recombinar antes de atingirem os terminais e formar o fluxo elétrico. Assim, nem todos os portadores gerados pela incidência de fótons conseguem atingir os terminais do diodo contribuindo para a corrente elétrica. Dentre outras coisas, é importante salientar que tanto com dispositivos sem porta ou com porta, o melhor é manter o alto fator de forma com um bom rendimento. Até o momento, foi verificado que é mais adequado utilizar um diodo com comprimento intrínseco de ordem de 6-8 $\mu \mathrm{m}$ nas condições apresentadas, visto que neste caso o fator de forma é máximo.

\subsection{A INFLUÊNCIA DA TEMPERATURA QUANTO AO DESEMPENHO DOS DISPOSITIVOS.}

Após inserir portas nos dispositivos e, consequentemente, verificar seu funcionamento com uma tensão gerada externamente, foi verificado o comportamento dos diodos PIN alterando a temperatura de trabalho de $300 \mathrm{~K}$ (temperatura ambiente, 27 graus Celsius) para 325K e 350K, 52 e 77 graus Celsius, respectivamente. Células solares costumam operar em temperatura ambiente ou maiores, visto que seu funcionamento adequado depende da radiação solar e o aquecimento que esta provê, tornando menos necessária a simulação e análise de células a temperaturas inferiores a ambiente que são aplicadas em estudos com satélites (57).

A seguir, nas figuras 35 a 43, são apresentadas as respectivas curvas de potência, correntes, tensões e dos rendimentos e fatores de forma alcançados em cada uma das temperaturas com a alteração de tensão e, logo depois, um gráfico comparativo com todas as temperaturas utilizadas. A curva obtida em $300 \mathrm{~K}$ é importante para criar o ambiente de comparação das demais temperaturas, já que nela está situada a temperatura ambiente, utilizada em todas as simulações até este ponto da pesquisa e com valores já conhecidos.

Partiu-se então para as primeiras simulações com aumento da temperatura de operação da célula solar, tendo assim uma aproximação cada vez maior em 
relação às condições reais como se pode ver nas figuras 35,36, 37 e 38 para valores de corrente em temperaturas de $325 \mathrm{~K}$ e $350 \mathrm{~K}$.

Figura 35 - Curva característica do dispositivo trabalhando a $325 \mathrm{~K}$ e tensão de porta nula.

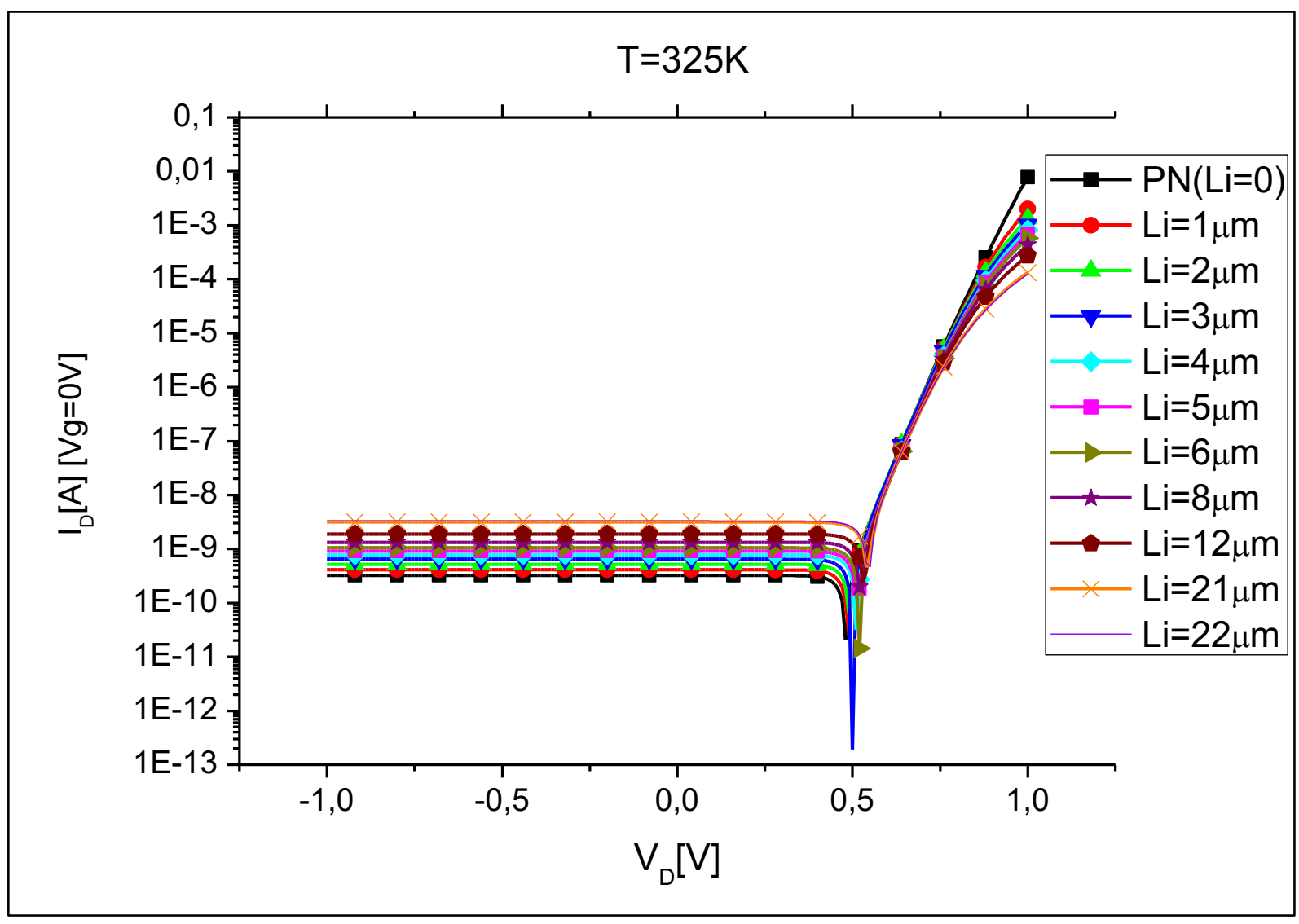

Fonte: Autoria própria. 
Figura 36 - Curva característica do dispositivo trabalhando a $325 \mathrm{~K}$ e tensão de porta de 5 volts.

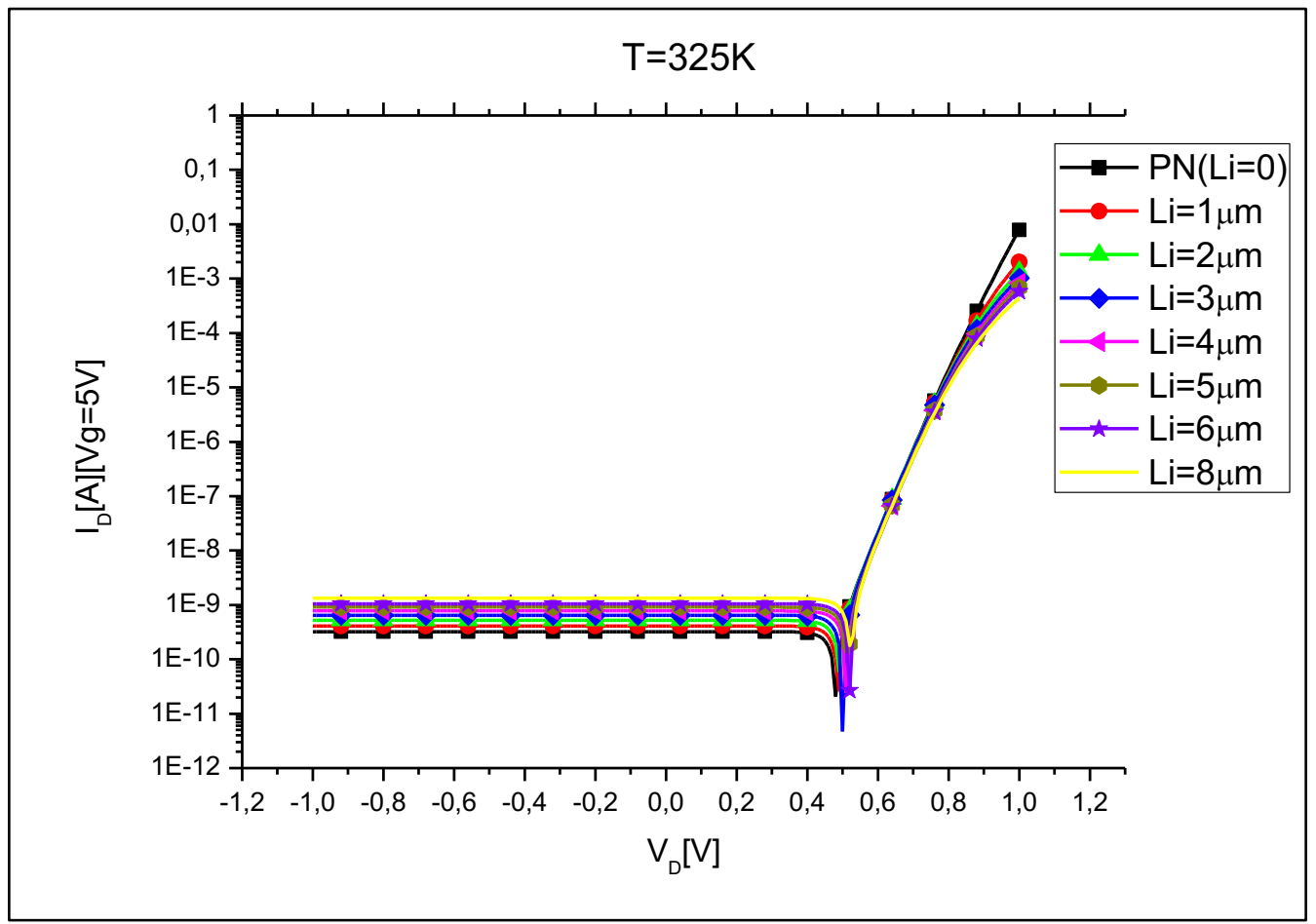

Fonte: Autoria própria.

Figura 37 - Curva característica do dispositivo trabalhando a $350 \mathrm{~K}$ e tensão de porta nula.

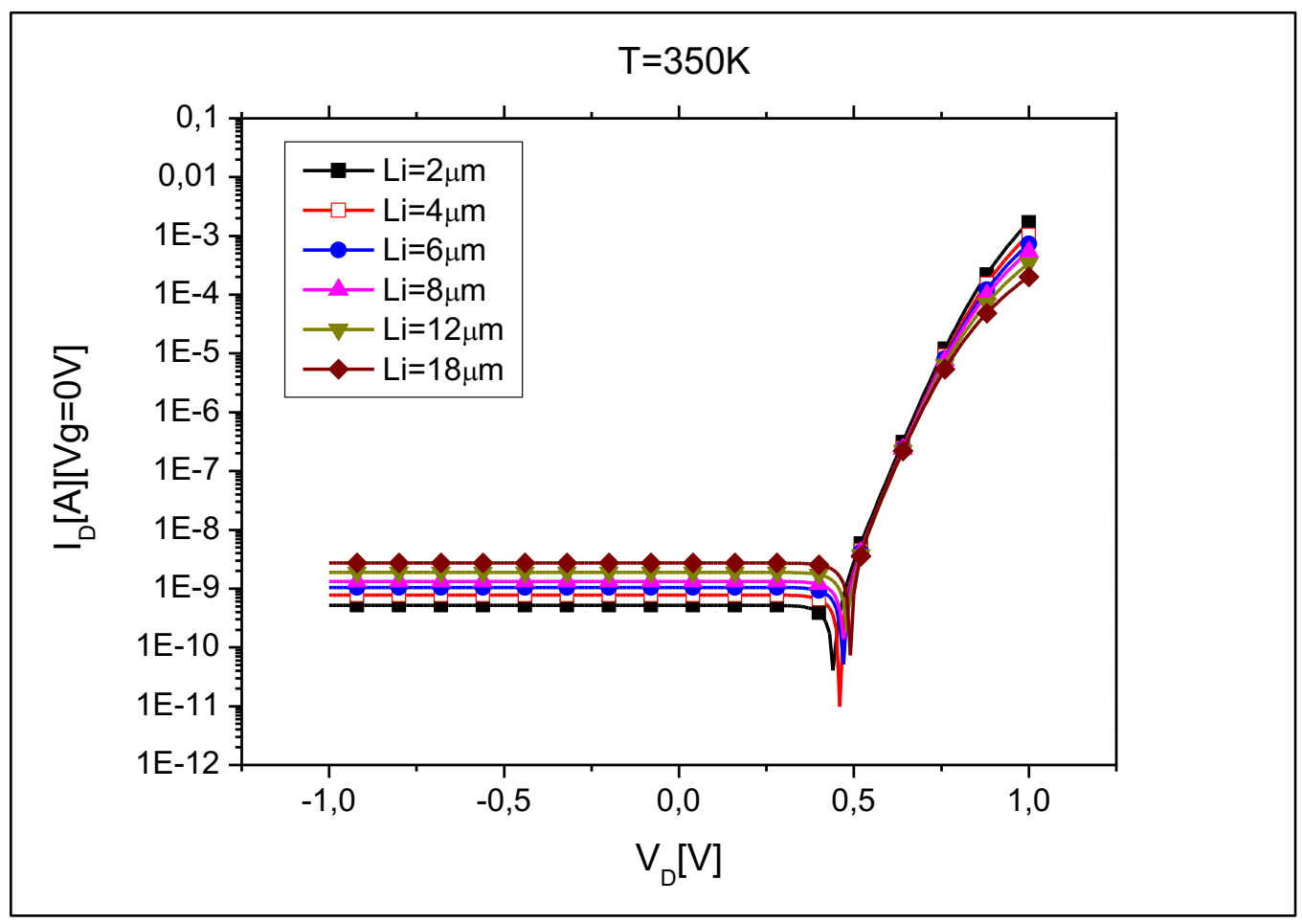

Fonte: Autoria própria 
Figura 38 - Curva característica do dispositivo trabalhando a 350K e tensão de porta de 5 volts.

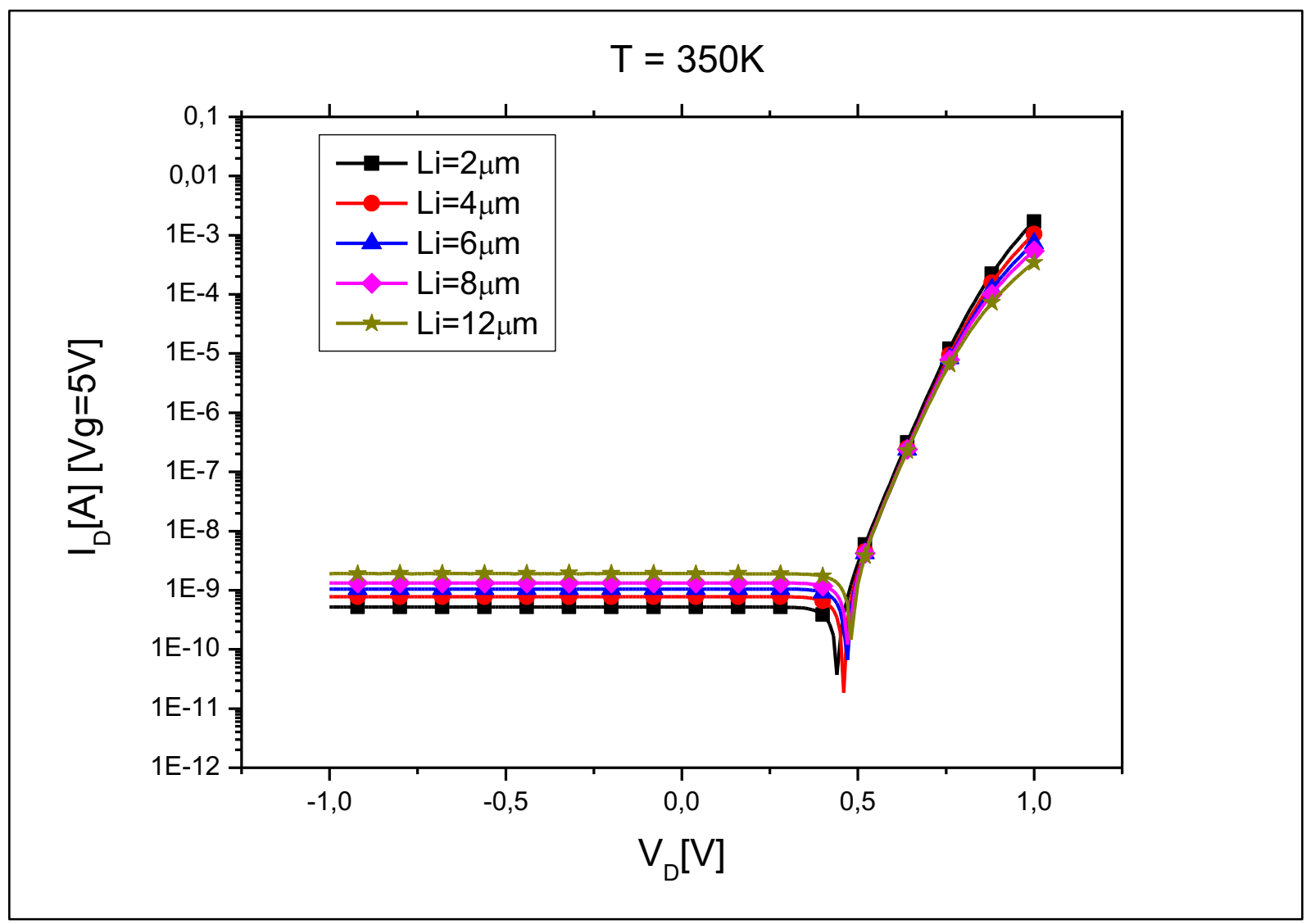

Fonte: Autoria própria

Tendo em mãos os valores das respectivas correntes e tensões, consequentemente, foram traçadas as curvas de potência dos dispositivos, que independente da temperatura ou da estrutura com porta ou sem porta mantiveram o comportamento em função de Li, porém $\mathrm{P}_{\max }$ sofreu uma alteração nos seus valores com a variação de temperatura. 
Figura 39 - Gráfico dos valores máximos de potência e potência incidente de ambas as tensões para $\mathrm{T}=325 \mathrm{~K}$ e $\mathrm{T}=350 \mathrm{~K}$.

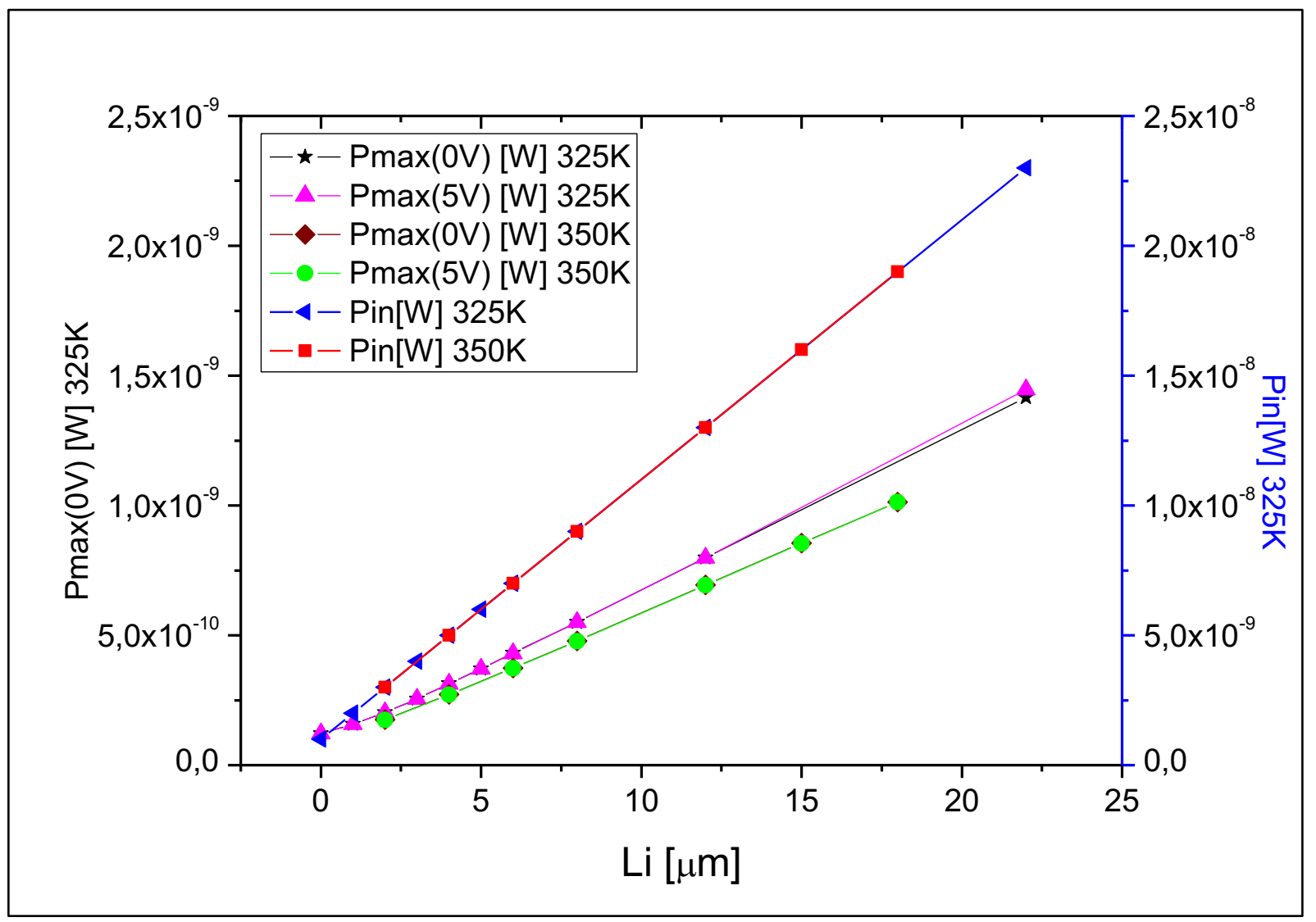

Fonte: Autoria própria.

No caso de se aumentar a temperatura a $350 \mathrm{~K}$ se vê uma perda nas potências máximas. As curvas para tensão nula e 5 volts de ambas as temperaturas estão quase sobrepostas o que significa que essa variação de tensão não representa mudanças nos parâmetros estudados.

Apresentadas as curvas de tensão e corrente e potência, o passo a seguir é contabilizar as tensões de circuito aberto e correntes de curto circuito e verificar o mesmo comportamento visto até agora em relação ao fator de forma e rendimento das células. A seguir, nas figuras 40 e 41, são apresentadas a representação gráfica dos dados extraídos de Voc e Isc das duas temperaturas, 325K e 350K, respectivamente. Pode-se observar que o comportamento de ambas as curvas em função da temperatura se assemelha ao observado para os mesmos dispositivos polarizados em $\mathrm{T}=300 \mathrm{~K}$. 
Figura 40 - Valores de corrente de curto circuito (ISc) e tensão de circuito aberto (Voc) para $\mathrm{T}=325 \mathrm{~K}$ e com variação da tensão de porta.

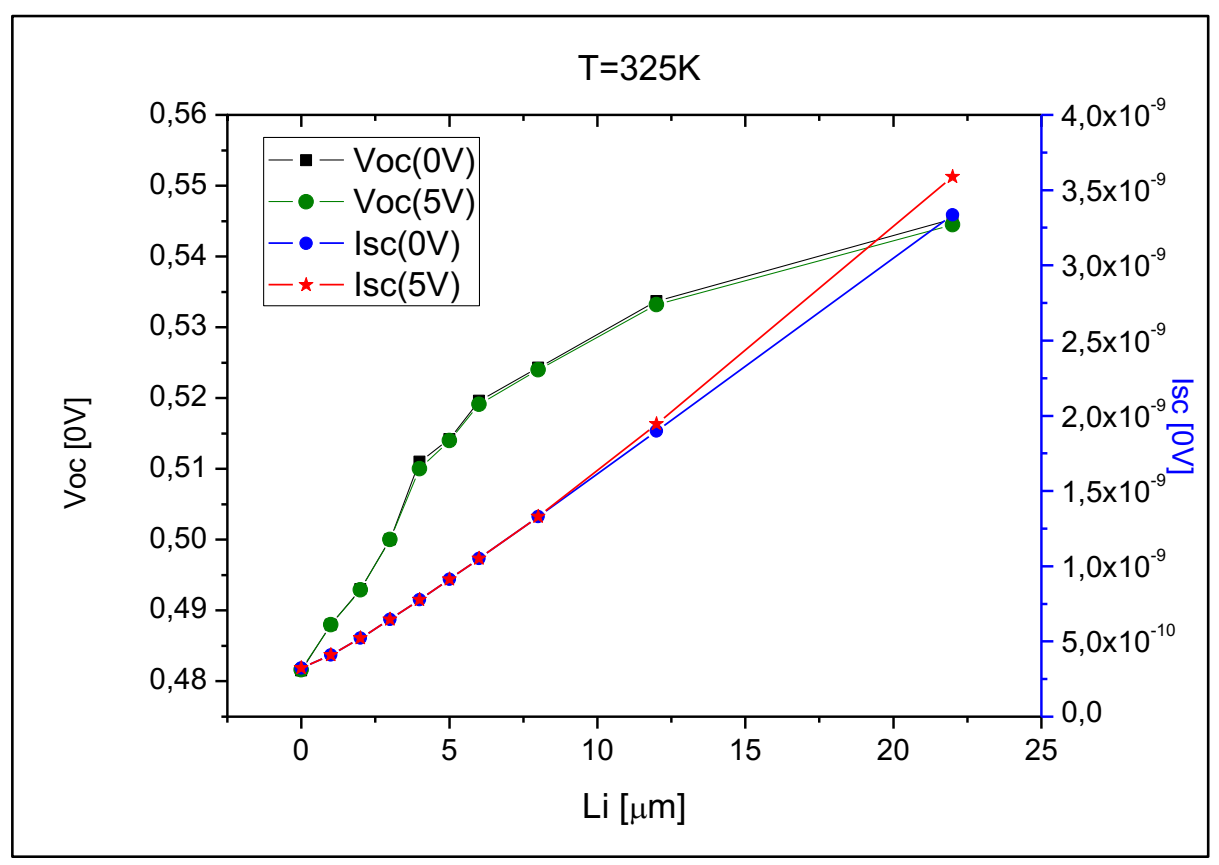

Fonte: Autoria própria.

Figura 41 - Valores de corrente de curto circuito (Isc) e tensão de circuito aberto (Voc) para $\mathrm{T}=350 \mathrm{~K}$ e com variação da tensão de porta.

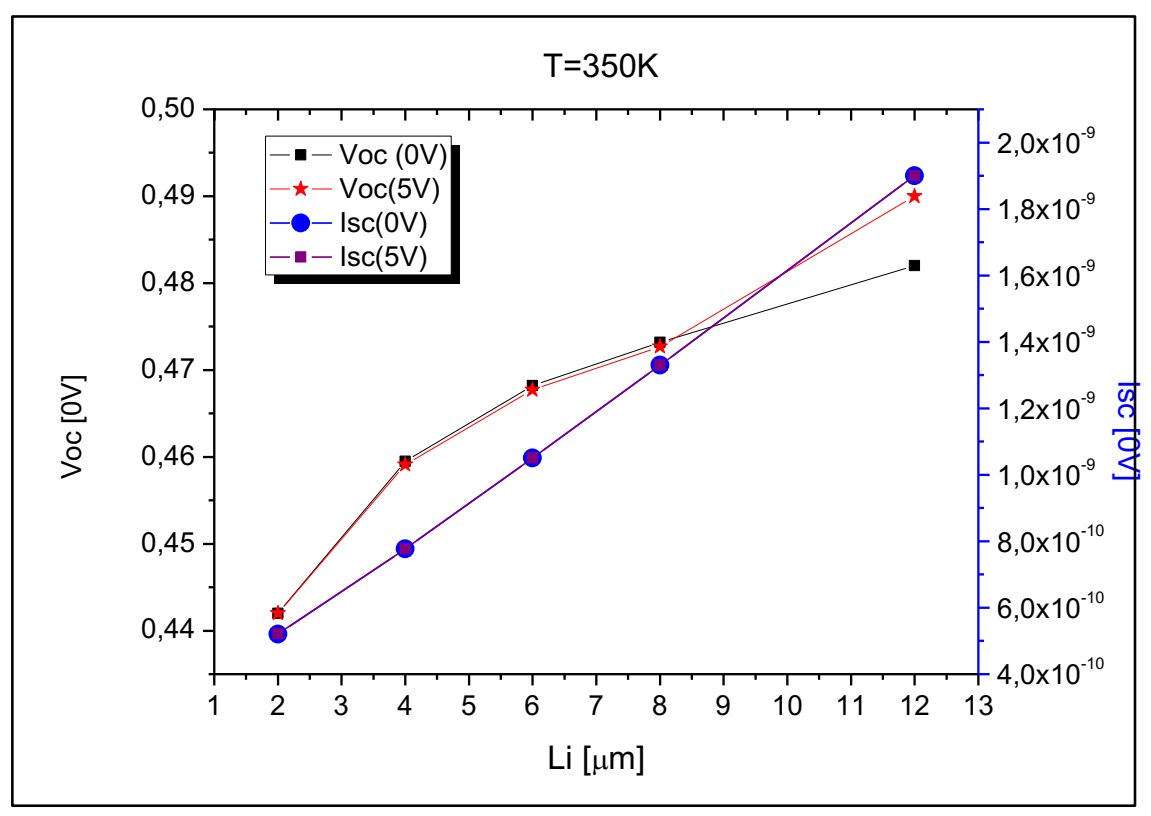

Fonte: Autoria própria.

$\mathrm{Na}$ figura 42 são apresentados os fatores de forma e rendimentos nas 3 temperaturas para que se faça as comparações adequadas dos resultados. 
Figura 42 - Comportamento do fator de forma relacionado ao aumento de temperatura.

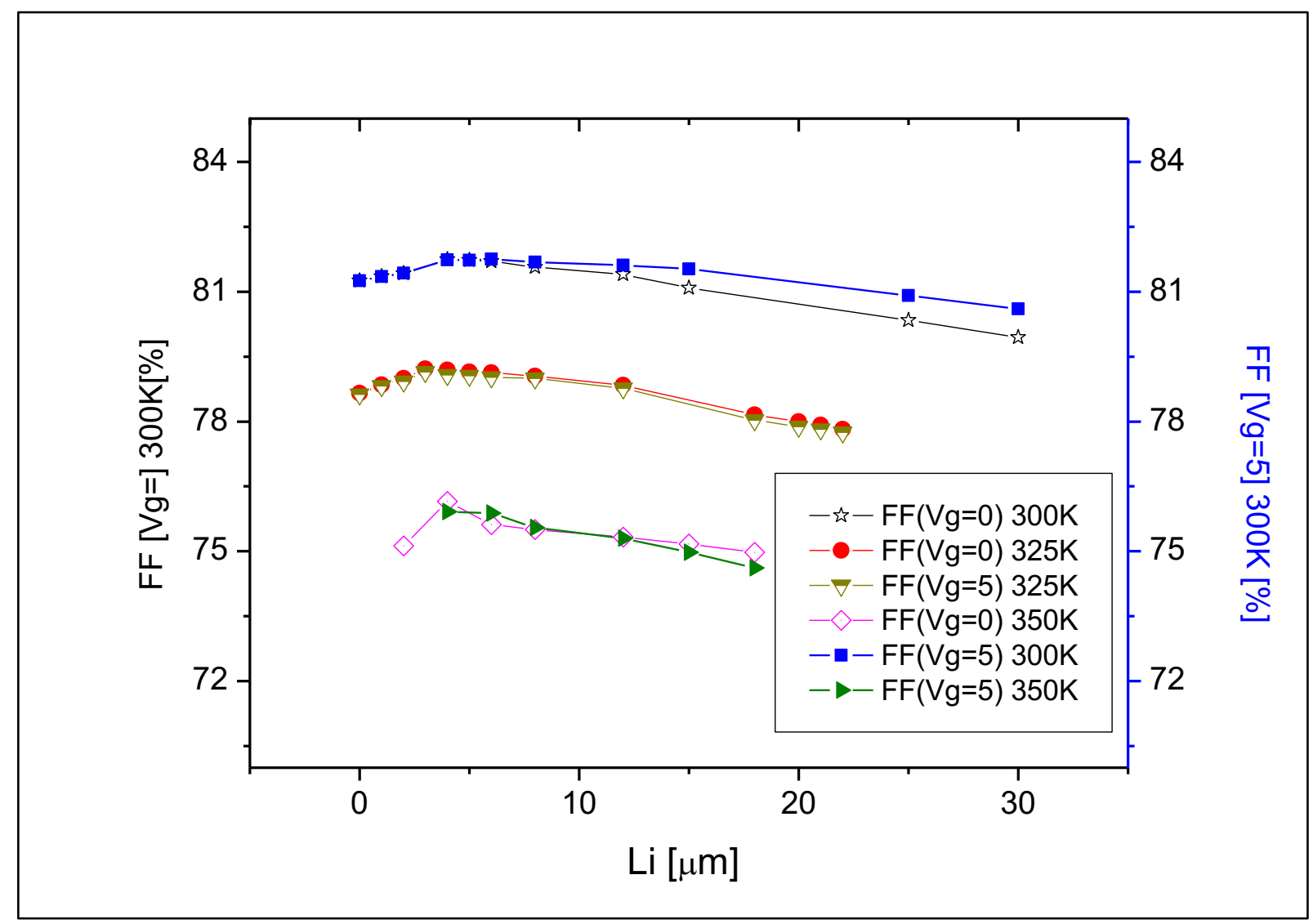

Fonte: Autoria própria.

A partir das curvas da figura 42, pode-se observar que, quanto maior a temperatura, menor é o fator de forma do dispositivo. À temperatura de $350 \mathrm{~K}$, o comportamento mantém o padrão e demonstra queda do fator de forma em decorrência da alta temperatura. O aquecimento intenso tem grande influência nas propriedades elétricas, como controle das cargas na região de depleção e dos campos elétricos gerados. Ao se aumentar a temperatura de operação, existe um aumento na agitação térmica dos portadores, reduzindo o seu comprimento de difusão e, por consequência, o fator de forma.

Com a célula operando a $325 \mathrm{~K}$ ou $52^{\circ}$ Celsius já se nota uma queda significativa no rendimento, a maior queda é apresentada no dispositivo sem região intrínseca, como se pode ver claramente na figura 43, onde são apresentadas todas as curvas simuladas em um mesmo gráfico com o intuito de proporcionar uma análise comparativa dos resultados obtidos. 
Figura 43 - Comparação entre os rendimentos relacionados por temperatura e tensão de porta ao comprimento intrínseco.

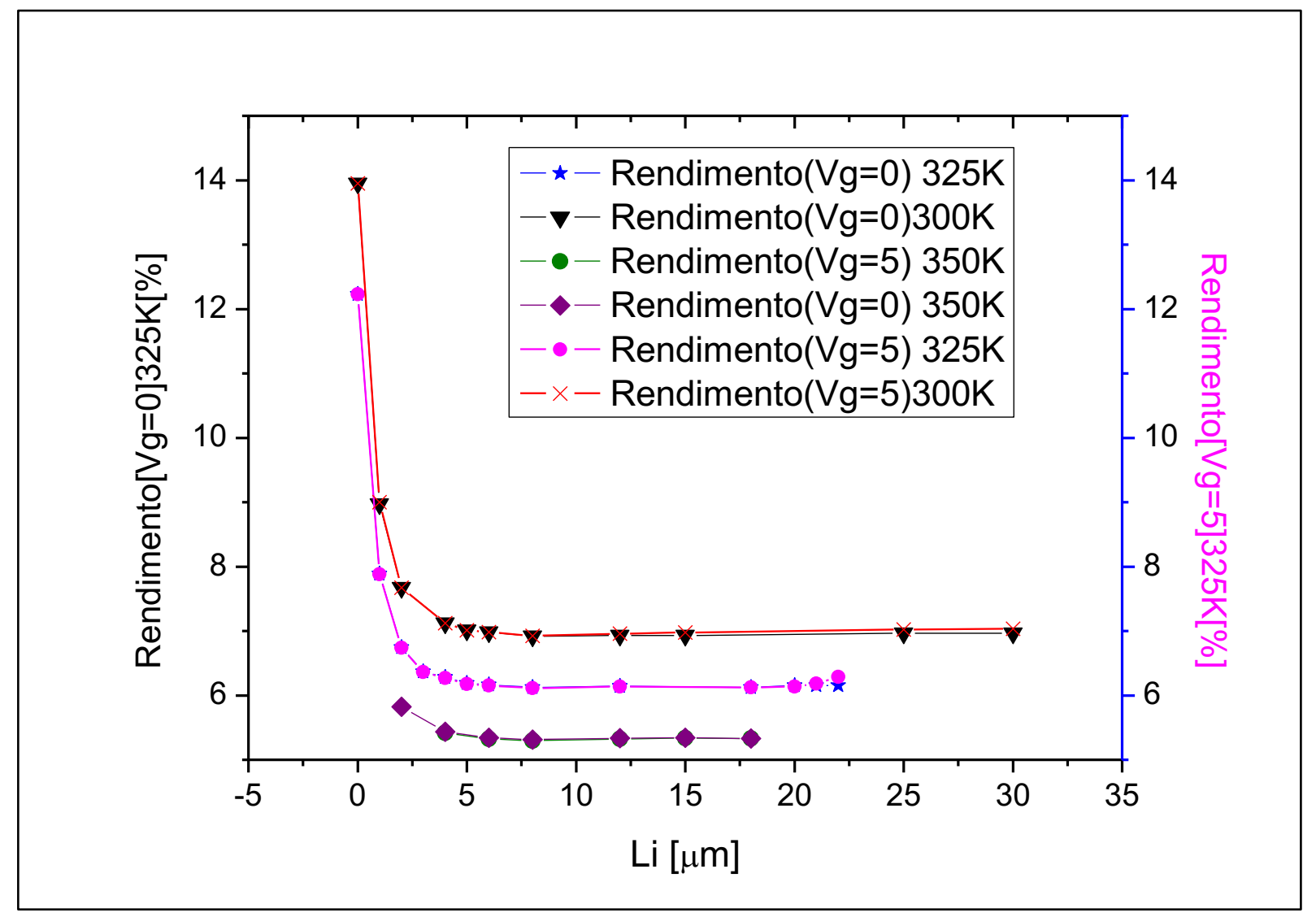

Fonte: Autoria própria.

Comparando os rendimentos, a partir do gráfico da figura 43 , de mesmos comprimentos intrínsecos das três temperaturas apresentadas, nota-se a queda no rendimento com o aumento da temperatura de operação. O rendimento do diodo PN caiu de $13,95 \%$ para $12,227 \%$ e o PIN de Li= $12 \mu \mathrm{m}$ de $6,931 \%$, para $6,142 \%$ e $5,336 \%$ ao se variar a temperatura de $300 \mathrm{~K}$ para $325 \mathrm{~K}$ e $350 \mathrm{~K}$, respectivamente. Foi verificado ainda que esta queda de rendimento é linear, pois a mesma queda que se tem no dispositivo de $\mathrm{Li}=2 \mu \mathrm{m}$ de $300 \mathrm{~K}$ para $325 \mathrm{~K}$, passa de $7,67 \%$ para $6,747 \%$ e depois em $350 \mathrm{~K}$, têm-se $5,824 \%$, dando uma queda aproximada de $0,92 \%$ de rendimento para cada $25 \mathrm{~K}$ de aumento na temperatura, análise que pode ser melhor observada através do gráfico da figura 44 . 
Figura 44 - Linearidade na queda dos rendimentos dos dispositivos de $2 \mu \mathrm{m}$ e $12 \mu \mathrm{m}$ de acordo com a temperatura, para tensão de 0 volts.

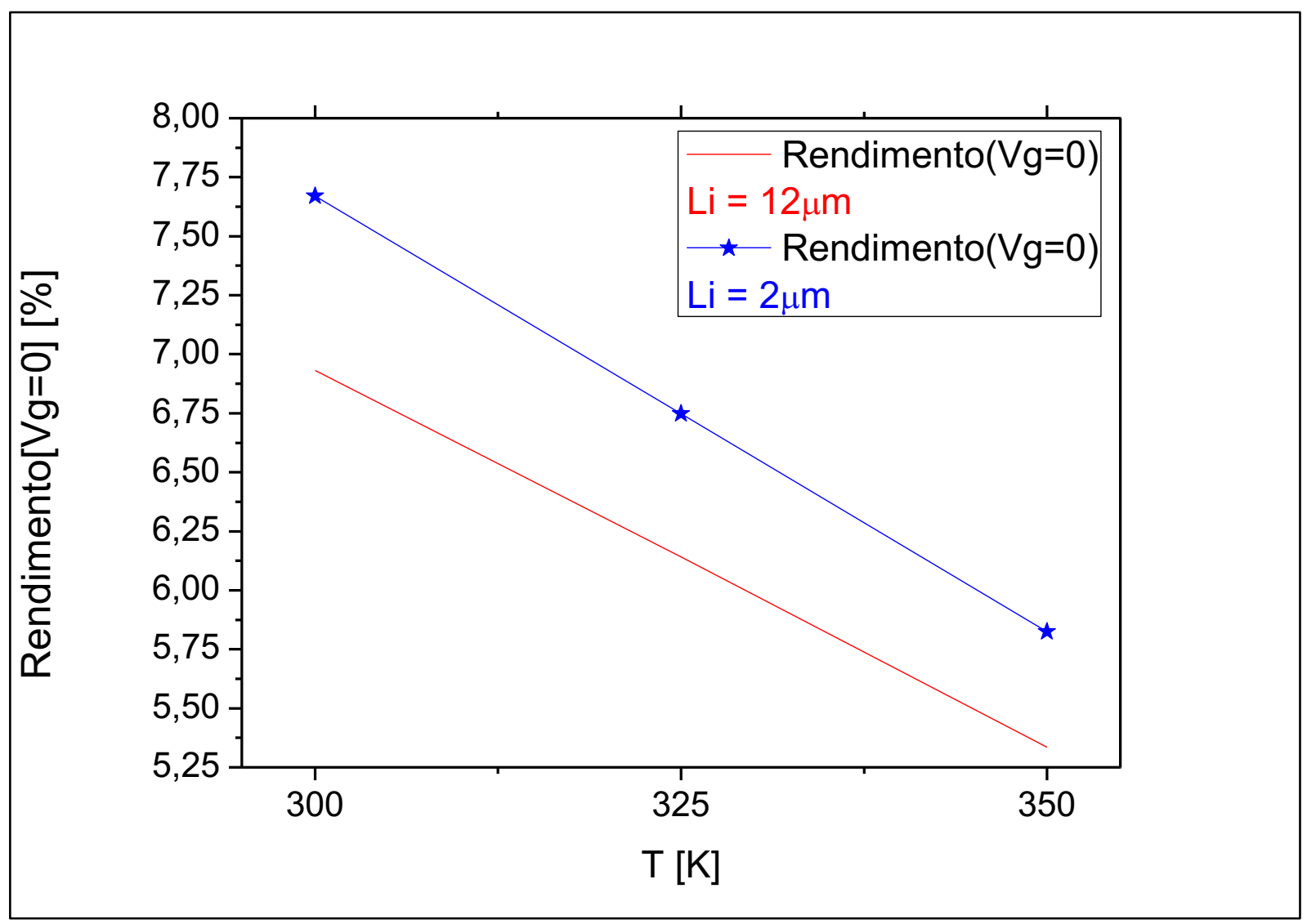

Fonte: Autoria própria, 2017.

Em relação à alteração de temperatura, o comportamento das células solares tem quedas lineares no aspecto rendimento. Está aí uma curva de comparação comprovando esta afirmação que foi vista nos demais dispositivos de comprimentos distintos. Esta queda se atenua à medida que o comprimento intrínseco aumenta, por mais que o efeito de recombinação pelo comprimento de difusão aumente, a temperatura mais alta diminui essa taxa de recombinação, tornando-a menos significativa. 


\section{Conclusões}

O trabalho atual teve como principal objetivo o estudo de células solares baseadas em diodos PIN e produzidas no substrato de lâminas SOI. Esta configuração resulta em um rendimento razoável na conversão de energia luminosa em eletricidade, o qual é diretamente dependente do comprimento da região com dopagem intrínseca dos dispositivos. Sabendo-se que o comprimento intrínseco tem uma influência muito forte no desempenho final do dispositivo, tendo em vista que são necessários tamanhos grandes o suficiente para se ter a região de depleção mais adequada, porém não tão grandes que possam fazer que o rendimento e o fator de forma sejam reduzidos de forma significativa, o estudo teve como principal objetivo determinar a faixa de comprimentos de região intrínseca mais adequada para a operação dos dispositivos em questão.

O estudo efetuado foi baseado em simulações bidimensionais de diodos PIN validadas através de dados experimentais. As simulações foram validadas a partir de dispositivos com fina camada de silício $(80 \mathrm{~nm})$, operando como fotodetectores de pequenos comprimentos de onda. Na sequência, foram efetuadas simulações considerando estruturas mais adequadas à operação como célula solar em que a espessura da camada de silício foi considerada como $2 \mu \mathrm{m}$. Neste caso, foi considerada a incidência de luz de acordo com o espectro solar AM1.5G.

As simulações dos diodos PIN operando como células solares demonstraram que a melhor relação de funcionamento dos dispositivos foi obtida para Li de 6 a 8 micrômetros, onde se obteve a melhor relação entre rendimento e fator de forma. Em relação à temperatura, notou-se que quanto mais alta é a temperatura, mais baixo é o rendimento. Este efeito está relacionado à maior agitação dos elétrons na camada intrínseca e, por isso, a taxa de recombinação dos portadores de carga aumenta. Entretanto, o comportamento do rendimento e do fator de forma em função de Li se manteve inalterado ao se variar a temperatura, ou seja, o comprimento ótimo da região intrínseca se manteve da ordem de 6-8 $\mu \mathrm{m}$.

Com relação à utilização de diodos PIN com porta em relação àqueles sem porta não foi possível notar diferença significativa em seu funcionamento. 
Aparentemente, os diodos PIN com porta induzem uma melhora no fator de forma e no rendimento dos dispositivos apenas para tensões de porta superiores a $5 \mathrm{~V}$, portanto, superiores a máxima tensão utilizada nos dispositivos analisados. 


\section{REFERÊNCIAS}

(1) FOSTER, Robert. Solar Energy: Renewable Energy and the Environment. Florida: Taylor \& Francis, 2010.

(2) WÜRFEL, Peter. Physics of Solar Cells. New York, NY, USA: Wiley, 2009.

(3) SCHOCKLEY, William B. QUEISSER, Hans-Joachim. Detailed Balance Limit Of Efficiency of P-N Junction Solar Cells. J.Appl.Phys., vol.32, 1961.

(4) COLINGE, Jean-Pierre. Physics of Seminconductor Devices, Kluwer Academic Publishers, 2000.

(5) COLINGE, J.P. Silicon-on-Insulator Technology: Materials to VLSI, Kluwer Academic Publishers, $3^{a}$ Ed., 2008.

(6) Synopsys, Sentaurus User Guide, Mountain View, 2015.

(7) COMETTA, Emilio. Energia Solar: utilização e empregos práticos. 1 ed. São Paulo: Hemus, 2004.

(8) ALDABÓ, Ricardo. Energia solar para produção de eletricidade. São Paulo: Artliber Editora, 2012.

(9) VILLALVA, Marcelo Gradella; GAZOLI, Jonas Rafael. Energia Solar Fotovoltaica: Conceitos e Aplicações, São Paulo, Érica, 2012.

(10) Levantamento do Potencial da Energia Solar Paulista. Disponível em: http://www.energia.sp.gov.br/portal.php/atlas-solar. Acesso em: 14 maio de 2017.

(11) LYRA, F. Energia solar: fundamentos e tecnologias de conversão heliotermoelétrica e fotovoltaica. Recife: UFPE.1995, 471p 
(12) BULTEEL, Olivier. Silicon-on-Insulator Optoelectronic Components for Micropower Solar Energy Harvesting and Bio-Environmental Instrumentation, PhD. Thesis, Université Catholique de Louvain, 2011.

(13) SZE, S.M. Physics of semiconductor devices, John Wiley and Sons, New York, 1981.

(14) M. A. Green, Solar Cells: Operating Principles, Technology and System Applications, Australia: University of New South Wales, 1982.

(15) ALDABÓ, Ricardo. Energia solar. São Paulo: Artliber Editora, 2002.

(16) BEZERRA, Arnaldo Moura. Aplicações térmicas da energia solar. 3 ed. João Pessoa: Universitária, 1998.

(17) PALZ, Wolfgang. Energia Solar e Fontes Alternativas. 2 ed. São Paulo: Hemus, 2005.

(18) CABIROL, Thierry. O Aquecedor solar de água. Lisboa: Edições Cetop, 1980.

(19) J. H. Lee et al, Solar Energy Mat. and Solar Cells, In Press,available online 1 May 2010.

(20) ALTENER. Energia Fotovoltaica - Manual sobre tecnologias, projeto e instalação. Projecto GREENPRO, janeiro de 2004.

(21) http://www.antonine-education.co.uk, acesso em janeiro de 2017.

(22) Espectro AM1.5 Dataset Online: http://rredc.nrel.gov/solar/spectra/am1.5/, último acesso feito em julho de 2017. 
(23) Ministério da Educação. Fontes Luminosas e Fotodetectores. Instituto Federal de Educação, Ciência e Tecnologia de Santa Catarina Campus São José Área de Telecomunicações.

(24) BOYLESTAD, R. L e NASHELSKY, L. Dispositivos Eletrônicos e Teoria de Circuitos, Prentice Hall, 10ª Ed., 2010.

(25) BIASI, Ronaldo S. MELLO, Hilton A. Introdução a Física dos Semicondutores.

(26) SCHOLZ, Ferdinand. Compound Semiconductors: Physics, Technology and Device Concepts. Pan Stanford, Germany, 2017.

(27) S.G.Streetman, S.Banerjee. Solid State Electronic Devices, 5a ed.,2000.

(28) SILVA, Domiciano Correa Marques. "Constante de Planck"; Brasil Escola. Disponível em <http://brasilescola.uol.com.br/fisica/constante-planck.htm>. Acesso em 27 de setembro de 2017.

(29) EISBERG, Robert; RESNICK, Robert. Física Quântica - Átomos, Moléculas, Sólidos, Núcleos e Partículas. Tradução de Paulo Costa Ribeiro, Ênio Costa da Silveira e Marta Feijó Barroso. Rio de Janeiro: Campus, 1979.

(30) GTEF - Grupo de trabalho de energia fotovoltaica - Sistemas fotovoltaicos. Manual de engenharia. 1. ed. Junho 1995

(31) WÜRFEL, Uli. WÜRFEL, Peter. CUEVAS, Andres. Charge Carrier Separation in Solar Cells. IEEE JOURNAL OF PHOTOVOLTAICS, VOL.5, NO.1, Janeiro 2015.

(32) Como a Célula Fotovoltaica funciona. Disponível em: http://www.eletrica.ufpr.br/edu/Sensores/2000/luischan/comofunciona.htm, acesso em março de 2017. 
(33) KININGER Franz; ENERGIEWANDLUNG, Rationele. Photovoltaic Systems Technology. Universidade de Kassel, Alemanha, 2003.

(34) MALVINO, Albert P. Eletrônica, Makron Books, 4ª Ed., 2006.

(35) MARTINO, J.A., PAVANELLO, M.A. e VERDONCK, P. Caracterização Elétrica de Tecnologia e Dispositivos MOS, Thomson, $1^{\text {a }}$ Ed., 2004.

(36) SEDRA, A.S. e SMITH, K. C. Microeletrônica, Pearson Prentice Hall, São Paulo, $5^{\mathrm{a}}$ Ed. 2007.

(37) MAHDI, Rana O. Measurement of Diffusion Length in P-N Junction Silicon Solar Cell, School of Applied Sciences, University of Technology, Iraq. Journal of AlNahrain University, Vol.11(1), April, 2008, pp.59-63.

(38) FORHAN, Neisy A. E. Fabricação de novas heteroestruturas a partir de estruturas SOI obtidas pela técnica "Smart Cut", Tese de Doutorado - Escola Politécnica da Universidade de São Paulo. São Paulo. 140p. 2006.

(39) ZIMMERMANN, H. Integrated Silicon Optoelectronics, Springer Series in Optical Science, Springer, Berlin, 2000.

(40) BÜHLER, Rudolf Theoderich. Estudo de Transistores Avançados de Canal Tensionado. 2014. 147p. Tese de Doutorado - Escola Politécnica da Universidade de São Paulo. São Paulo.

(41) NOVO, Carla D.C. Estudo Comparativo de Tecnologias CMOS e SOI-CMOS Aplicadas a Fotodiodos Laterais PIN. 2013. 150 f. Dissertação de Mestrado. Centro Universitário FEI, São Bernardo do Campo

(42) BRAGA, Newton. Estudo Teórico experimental do Efeito Tiristor Parasitário (Latch Up) em Estruturas CMOS. Dissertação de Mestrado, Escola Politécnica da Universidade de São Paulo, 1989. 
(43) FORHAN, Neisy A. E. Solda Direta para Obtenção de Lâminas SOl com tecnologia "Smart Cut", Dissertação de Mestrado, Escola Politécnica da Universidade de São Paulo, 2000.

(44) CULLEN, Glenn W; WANG, Chin-Chun. Heteroepitaxial Semiconductors for Electronic Devices. Netherlands, V.S. Ban, 1978.

(45) SHAO, H; TSUI, C. Y; KI, W.H. A Micro Power Management System and Maximum Output Power Control for Solar Energy Harvesting Applications, Proceedings The International Symposium on Low Power Electronics and Design 2007, Portland - OR/USA, 2007.

(46) J.-P. Colinge, P-I-N Photodiodes Made in Laser-recrystallized Silicononinsulator, IEEE Trans. Electron Devices 33(2), pp. 203-205, 1986.

(47) A. Afzalian and D. Flandre, Physical Modeling and Design of Thin-Film SOI Lateral PIN Photodiodes, IEEE Transactions on Electron Devices, Vol. 52, No. 6, pp. 1116-1122, June 2005.

(48) GRIFFIOEN, C.C.; EVANS, J.H.; JONG, P.C. De. Nuclear Instruments in Physics Research Section B: Beam Interactions Materials and Atoms. 1987.

(49) GIACOMINI, Renato C.; PERIN, André Luiz; AGOPIAN, Paula Ghedini Der. Study of Simulation Mobility Models for Electronic Devices. 2010.

(50) SCHENK, Andreas. Finite-Temperature Full Random-Phase Approximation Model of Band Gap Narrowing for Silicon Device Simulation. Journal of Applied Physics, January, 1998.

(51) SHOCLKEY, William; SAH, Chih-Tang; NOYCE, Robert N. Carrier Generation and Recombination in P-N Junctions and $P-N$ Junction Characteristics. Proceedings of IRE, september, 1957. 
(52) KARL, Norbert; MARKTANNER, Jörg. High-Field Saturation of Charge Carrier Drift Velocities in Ultrapurified Organic Photoconductors. Physikalisches Institut der Universität Stuttgart. Synthetic Metals, 41-43, 1991.

(53) LOMBARDI, Claudio; MANZINI, Stefano; SAPORITO, Antonio. A Physically Based Mobility Model for Numerical Simulation of Nonplanar Devices. IEEE Transactions on Computer-Aided Design. Vol 7. No. 11. November, 1988.

(54) ALTERMATT, Pietro T. Models for Numerical Simulations of Crystalline Silicon Solar Cells - A Review. Journal of Computational Electronics, September, 2011.

(55) WACHUTKA, Gerhard K. Rigorous Thermodynamic Treatment of Heat Generation and Conduction in Semiconductor Device Modeling, IEEE Transactions on Computer-Aided Design. Vol 9. No. 11. November, 1990.

(56) SOUZA, Michelly de. Analysis of Lateral SOI PIN Diodes for the Detection of Blue and UV Wavelengths in a Wide Temperature Range, Departamento de Engenharia Elétrica, Centro Universitário da FEI, São Bernardo do Campo, Brasil, p.202, 2010.

(57) SOUZA, Michely de; BULTEEL, Olivier; FLANDRE, Dennis and PAVANELLO, Marcelo A., Temperature Influence on the Behaviour of Lateral Thin-Film SOI PIN Photodiode in the Blue and UV Range, Proceedings of the EuroSOI Conference 2010, Grenoble/France, January, pp.25-27, 2010.

(58) SOUZA, Michely de; BULTEEL, Olivier; FLANDRE, Dennis and PAVANELLO, Marcelo A., Electrical Characterization of SOI Solar Cells in a wide temperature Range, Departamento de Engenharia Elétrica, Centro Universitário da FEI, São Bernardo do Campo, Brasil, p.92, 2010. 
(59) G. Gosset, O. Bulteel, P. Baijot and D. Flandre, Ultra-High-Efficiency CoIntegrated Photovoltaic Energy Scavenger, Proceedings of SOI Conference, 2011, Tempe - AZ/USA, October 3-6, 2011.

(60) RAMPAZZO, Lino. Metodologia Científica. 3ed. São Paulo: Loyola, 2005.

(61) RICCI, Delcinio; MESSAGE, Eliane Regina Rodrigues; DUARTE, Jacy Marcondes. Manual de normalização de trabalho de conclusão de curso. São Bernardo do Campo: FATEC São Bernardo, 2012.

(62) SEVERINO, Antônio Joaquim. Metodologia do Trabalho Científico. 22ed. São Paulo: Cortez Editora, 2006.

(63) LI, Jianming. Applied Physics Letters. (1989), 55(21), 2223-4 CODEN: APPLAB; ISSN: 0003-6951. English.

(64) INSTITUTE OF ELECTRICAL AND ELECTRONIC ENGINEERS - IEEE 603647-712 Electrical installations of buildings - Part 7-712: Requirements for special installations or locations - Solar photovoltaic (PV) power supply systems. July 2002.

(65) INSTITUTE OF ELECTRICAL AND ELECTRONIC ENGINEERS - IEEE 1547.22008 - IEEE Application Guide for IEEE Std 1547(TM), IEEE Standard for Interconnecting Distributed Resources with Electric Power Systems. April, 2009. 


\section{APÊNDICE A - ARQUIVO DE SIMULAÇÃO DA ESTRUTURA DE UM DIODO PIN COM LI = 20 $\mu \mathrm{m}$, SUBSTRATO FINÍSSIMO E SEM PORTA.}

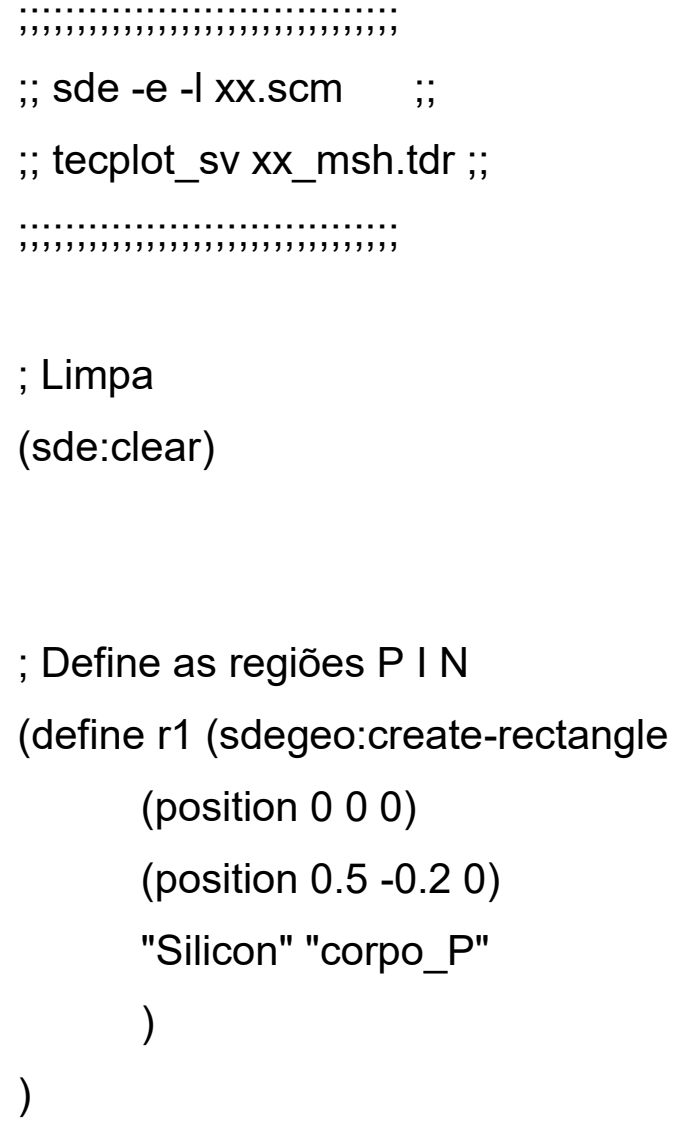




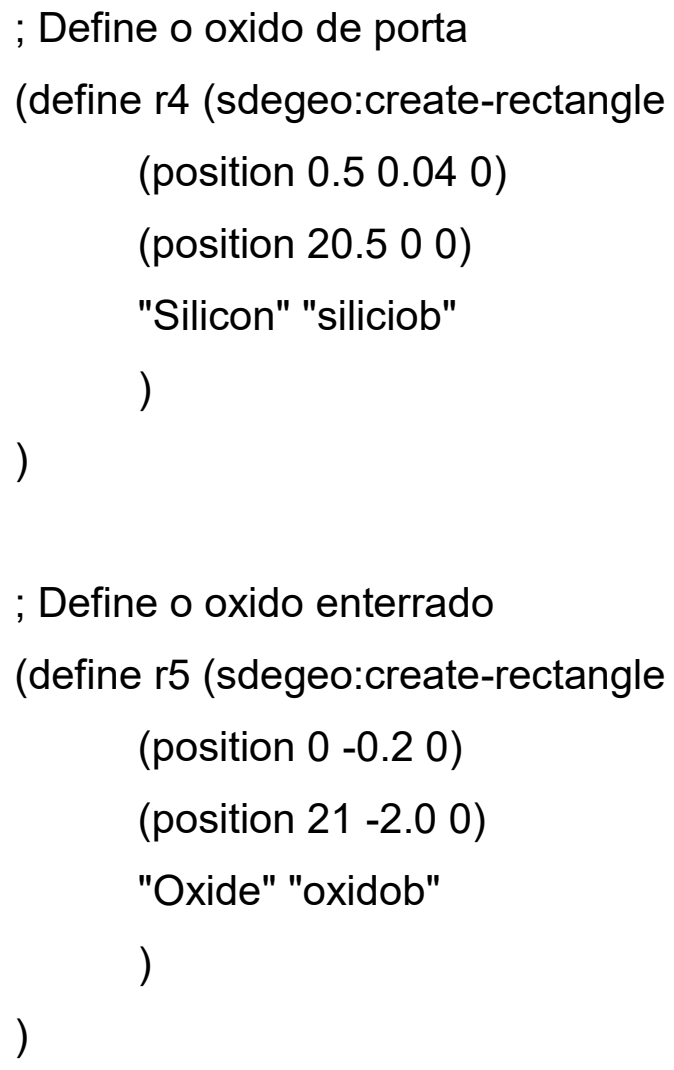

; Contato de porta

;(sdegeo:define-contact-set "porta" 0.001 (color:rgb 10 0) "\#\#")

;(sdegeo:set-current-contact-set "porta")

;(sdegeo:define-2d-contact (list (car (find-face-id (position $10.5 ; 0.04 \quad$ )))) "porta")

; Contato lado P 
(sdegeo:define-contact-set "Lado_P" 0.001 (color:rgb 10 0) "\#\#")

(sdegeo:set-current-contact-set "Lado_P")

(sdegeo:define-2d-contact (list (car (find-edge-id (position 0 -0.04 0 ))) "Lado_P")

; Contato lado $\mathrm{N}$

(sdegeo:define-contact-set "Lado_N" -0.001 (color:rgb 10 o) "\#\#")

(sdegeo:set-current-contact-set "Lado_N")

(sdegeo:define-2d-contact (list (car (find-edge-id (position $21 \quad-0.04 \quad 0)$ ))) "Lado_N")

; Contato do substrato

(sdegeo:define-contact-set "substrato" -0.001 (color:rgb 10 0) "\#\#")

(sdegeo:set-current-contact-set "substrato")

(sdegeo:define-2d-contact (list (car (find-edge-id (position 10.5 -2.0 0 ))) "substrato")

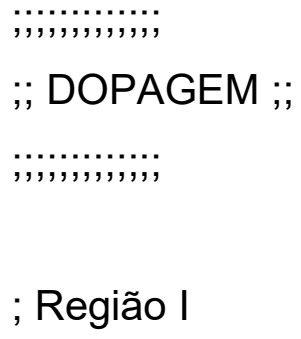


(sdedr:define-constant-profile

"definicao_perfil_constante_canal"

"BoronActiveConcentration" 1e15)

(sdedr:define-constant-profile-material "placement_perfil_constante_canal" "definicao_perfil_constante_canal" "silicon")

; Lado P

(sdedr:define-refeval-window "DopGaussDrenoJan" "Rectangle" (position 00

0) (position $0.5-0.20)$ )

(sdedr:define-gaussian-profile

"DopGaussDrenoDef"

"BoronActiveConcentration" "PeakPos" 0 "PeakVal"1e20 "Length" 0.01 "Gauss" "Length" 0)

(sdedr:define-analytical-profile-placement

"DopGaussDreno"

"DopGaussDrenoDef" "DopGaussDrenoJan" "Both" "NoReplace" "Eval")

; Lado N

(sdedr:define-refeval-window "DopGaussFonteJan" "Rectangle" (position 20.5

0 0) (position $21-0.20)$ )

(sdedr:define-gaussian-profile

"DopGaussFonteDef"

"ArsenicActiveConcentration" "PeakPos" 0 "PeakVal" 4e20 "Length" 0.01 "Gauss" "Length" 0)

(sdedr:define-analytical-profile-placement

"DopGaussFonte"

"DopGaussFonteDef" "DopGaussFonteJan" "Both" "NoReplace" "Eval")

,$;, ;, ;, ;, ; ;$

;; GRADE ;;

,,$;, ;, ;, ;, ; ;$

;Canal

(sdedr:define-refinement-size "DefRef0" $\quad 0.050 .0050 .030 .003$ )

(sdedr:define-refinement-material "Ref1" "DefRef0" "Silicon" ) 
;oxido

(sdedr:define-refinement-size $\quad$ "DefRef1" $0.05 ; 0.0005 \quad 0.03$ 0.0003 )

(sdedr:define-refinement-region "Ref2" "DefRef1" "oxido" )

(sdedr:define-refinement-size "DefRef2" $\quad 0.050 .050 .030 .04$ ) (sdedr:define-refinement-region "Ref3" "DefRef2" "oxidob" )

(sdedr:define-refinement-function "DefRef0" "MaxLenInt" ;"Silicon" "Oxide" 0.00052 )

(sdedr:define-refinement-function "DefRef0" "MaxLenInt" "corpo_f" "corpo" 0.0012 "DoubleSide" "UseRegionNames")

(sdedr:define-refinement-function "DefRef0" "MaxLenInt" "corpo_d" "corpo" 0.0012 "DoubleSide" "UseRegionNames")

; (sdedr:define-refinement-function "DefRef0" "DopinConcentration" "MaxTransDiff" 1e10)

.........................

;; CONSTRUCAO DA GRADE ;;

;,;,;,;,;,;,;,;,;,;,;,;

;(sde:build-mesh "mesh" "-P -R -F tdr" nome)

;(sde:build-mesh "snmesh" "-a -c boxmethod -m 50000 -R " nome) 
(sde:build-mesh "snmesh" "'" "Li8um-T300_msh.tdr"

\section{APÊNDICE B - ARQUIVO DE SIMULAÇÃO DA CARACTERÍSTICA I X V DE UM DIODO PIN}

\#\# IxV

File \{

* output files:

Output = "IxV_Li8um.log"

IlluminationSpectrum = "illumination_spectrum.txt"

\}

Physics \{

Temperature $=300$

Mobility (

\#

Phumob

Enormal

HighFieldSaturation

)

Recombination( SRH(DopingDep TempDependence)

)

EffectivelntrinsicDensity (BandGapNarrowing (OldSlotboom))

\}

\#Physics (Material="Silicon") \{ eQuantumPotential\}

Physics \{

Optics (

OpticalGeneration (

ComputeFromSpectrum

)

Excitation ( 


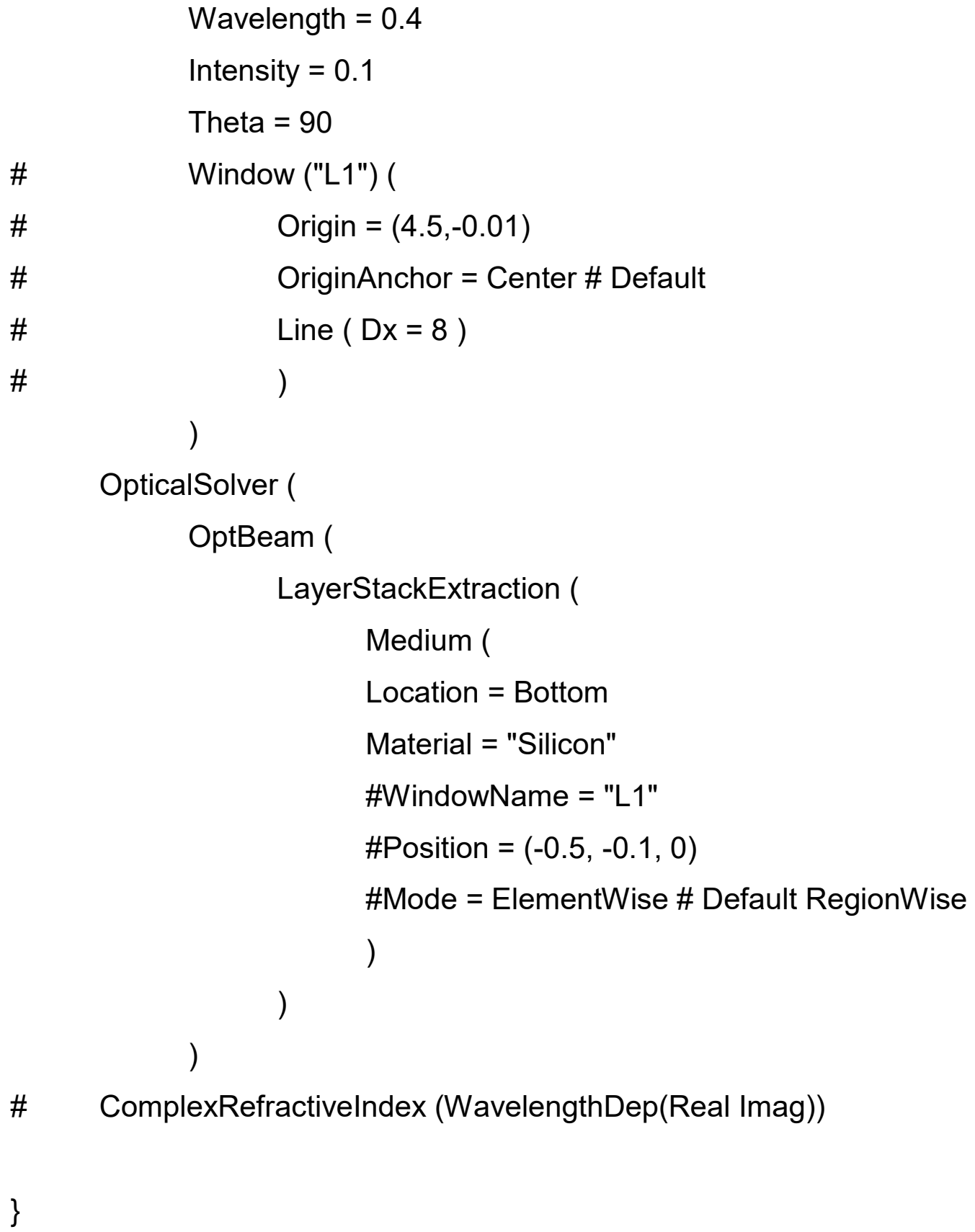

Device Fin47\{

File \{

* input files:

Grid = "Li8um-T300_msh.tdr"

Doping = "Li8um-T300_msh.tdr"

\# $\quad$ Parameter = "Param5.2.par"

* output files: 


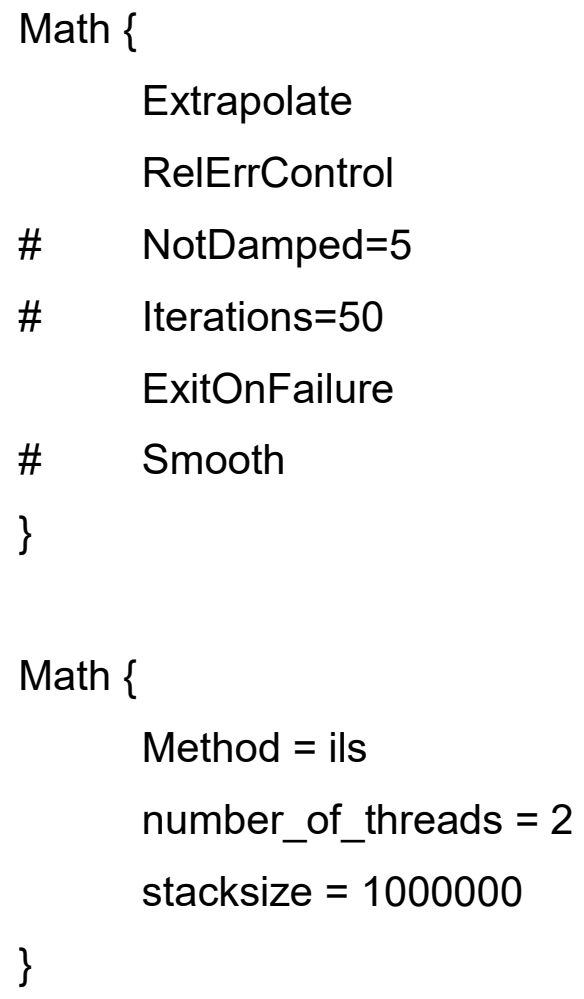


Quasistationary

( Initialstep=1 Minstep=1e -5 Maxstep=1

Goal $\{$ Parameter $=$ Vp.dc Value $=1\}$ )

\{

Coupled $\quad$ Poisson Electron Hole

CurrentPlot $\left(\right.$ Time $=\left(\right.$ range $=\left(\begin{array}{ll}0 & 1\end{array}\right)$ intervals $\left.\left.=200\right)\right)$

\}

\} 